Regina de Sousa Bolina-Matos

\title{
Efeitos da Biomembrana de Látex Natural (Hevea brasiliensis) em pele de ratos Wistar submetidos à lesão térmica corporal por escaldamento
}




\section{LISTA DAS PRINCIPAIS ABREVIATURAS E SIGLAS}

BML Biomembrana de Látex natural

LTE Lesão Térmica por Escaldamento

MEV Microscopia Eletrônica de Varredura

CV Coeficiente de variação

$\mathbf{V}_{\mathbf{v}} \quad$ Densidade de volume

X Média

$\mu \mathrm{m}$ micrômetro

dp desvio padrão

H.E Hematoxilina e eosina (coloração)
GI Grupo I - Controle

GI(4) Grupo I - Controle (4 dias)

GI(14) Grupo I - Controle (14 dias)

GII Grupo II - Queimado

GII(4) Grupo II - Queimado (4 dias)

GII(14) Grupo II - Queimado (14 dias)

GIII Grupo III - Tratado

GIII(4) Grupo III - Tratado (4 dias)

GIII(14) Grupo III - Tratado (14 dias)

\section{LISTA DAS PRINCIPAIS ABREVIATURAS E SIGLAS}

BML Biomembrana de Látex natural

LTE Lesão Térmica por Escaldamento

MEV Microscopia Eletrônica de Varredura

CV Coeficiente de variação

$\mathbf{V}_{\mathbf{v}} \quad$ Densidade de volume

$\mathrm{X} \quad$ Média

um micrômetro

dp desvio padrão

H.E Hematoxilina e eosina (coloração)
GI Grupo I - Controle

GI(4) Grupo I - Controle (4 dias)

GI(14) Grupo I - Controle (14 dias)

GII Grupo II - Queimado

GII(4) Grupo II - Queimado (4 dias)

GII(14) Grupo II - Queimado (14 dias)

GIII Grupo III - Tratado

GIII(4) Grupo III - Tratado (4 dias)

GIII(14) Grupo III - Tratado (14 dias)

\section{LISTA DAS PRINCIPAIS ABREVIATURAS E SIGLAS}

BML Biomembrana de Látex natural

LTE Lesão Térmica por Escaldamento

MEV Microscopia Eletrônica de Varredura

CV Coeficiente de variação

$\mathbf{V}_{\mathbf{v}} \quad$ Densidade de volume

X Média

um micrômetro

dp desvio padrão

H.E Hematoxilina e eosina (coloração)
GI Grupo I - Controle

GI(4) Grupo I - Controle (4 dias)

GI(14) Grupo I - Controle (14 dias)

GII Grupo II - Queimado

GII(4) Grupo II - Queimado (4 dias)

GII(14) Grupo II - Queimado (14 dias)

GIII Grupo III - Tratado

GIII(4) Grupo III - Tratado (4 dias)

GIII(14) Grupo III - Tratado (14 dias)

\section{LISTA DAS PRINCIPAIS ABREVIATURAS E SIGLAS}

BML Biomembrana de Látex natural

LTE Lesão Térmica por Escaldamento

MEV Microscopia Eletrônica de Varredura

CV Coeficiente de variação

$\mathbf{V}_{\mathbf{v}} \quad$ Densidade de volume

X Média

um micrômetro

dp desvio padrão

H.E Hematoxilina e eosina (coloração)
GI Grupo I - Controle

GI(4) Grupo I - Controle (4 dias)

GI(14) Grupo I - Controle (14 dias)

GII Grupo II - Queimado

GII(4) Grupo II - Queimado (4 dias)

GII(14) Grupo II - Queimado (14 dias)

GIII Grupo III - Tratado

GIII(4) Grupo III - Tratado (4 dias)

GIII(14) Grupo III - Tratado (14 dias) 

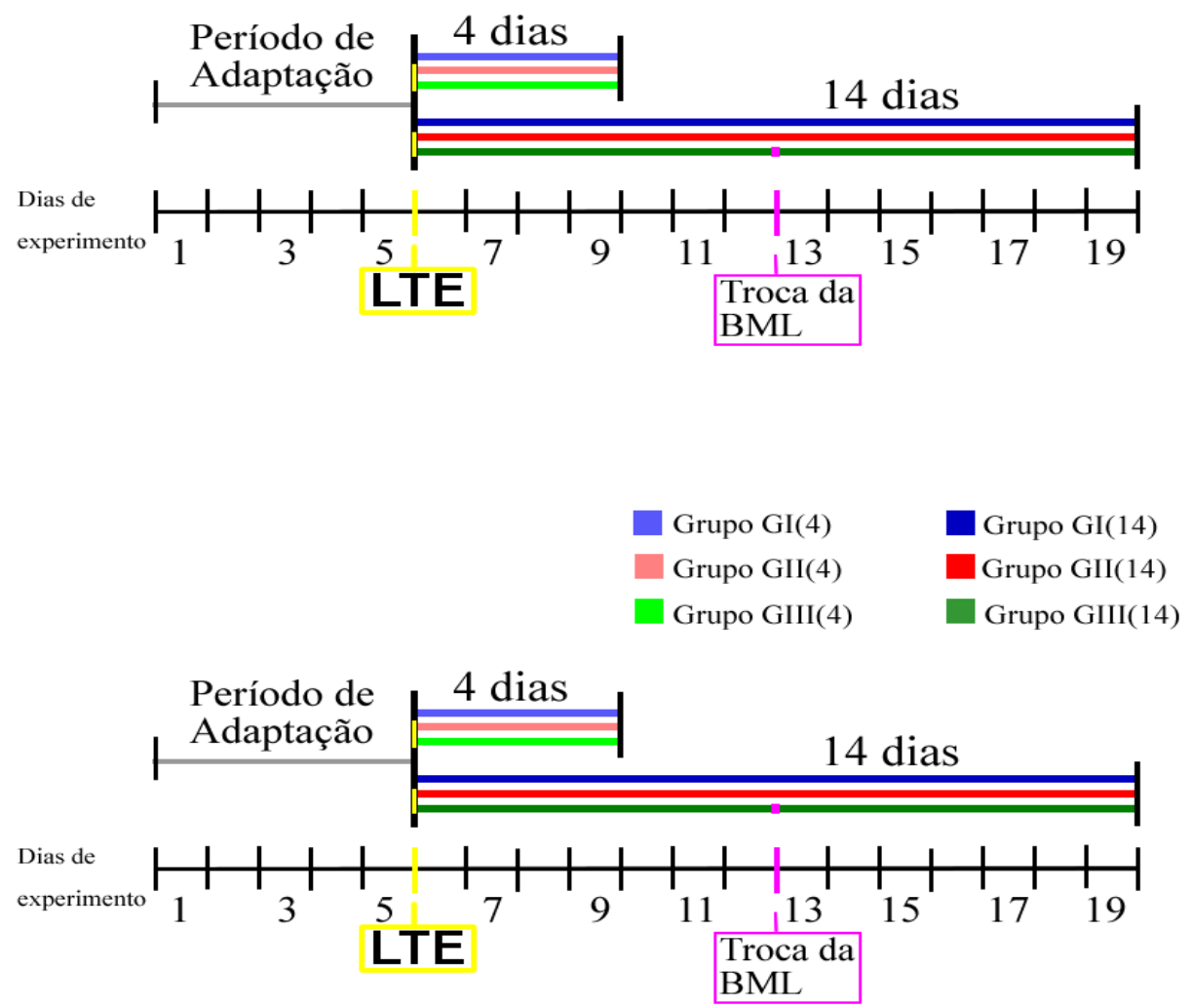

Grupo GI(4)
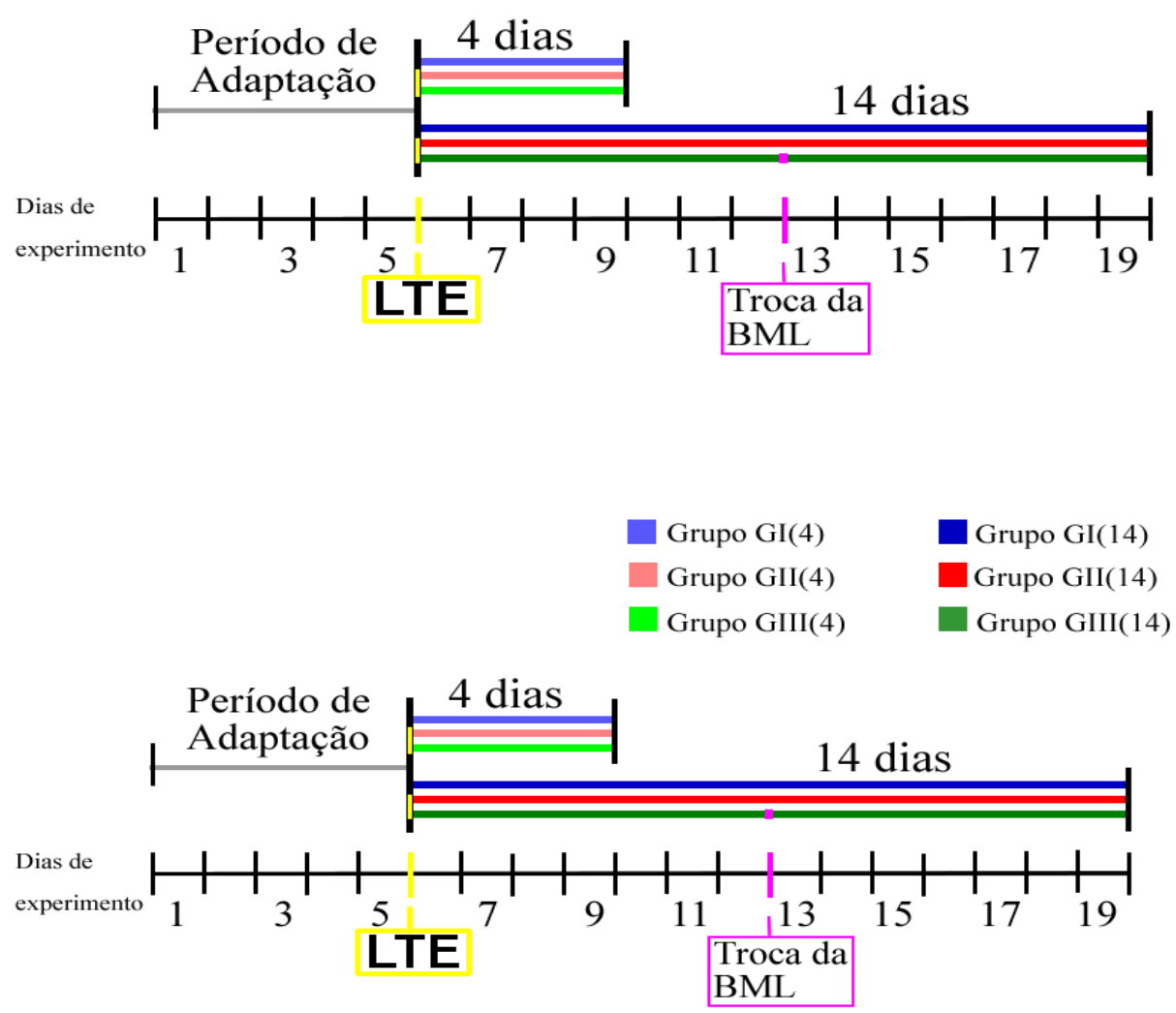


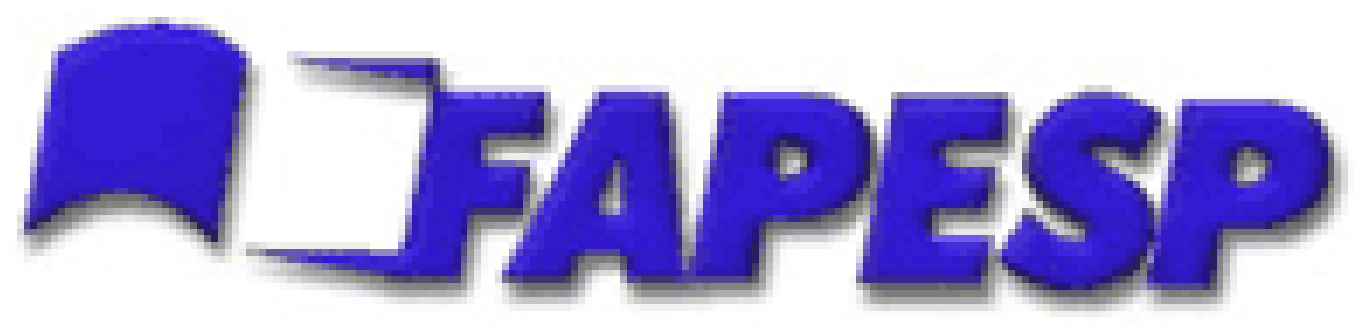

Processo 2008/54444-9 


\section{Regina de Sousa Bolina-Matos}

Efeitos da biomembrana de látex natural (Hevea brasiliensis) em pele de ratos Wistar submetidos à lesão térmica corporal por escaldamento 


\section{Regina de Sousa Bolina-Matos}

Efeitos da biomembrana de látex natural (Hevea brasiliensis) em pele de ratos Wistar submetidos à lesão térmica corporal por escaldamento

Dissertação apresentada ao Programa de Pós-Graduação em Anatomia dos Animais Domésticos e Silvestres da Faculdade de Medicina Veterinária e Zootecnia da Universidade de São Paulo para obtenção do título de Mestre em Ciências

Departamento:

Cirurgia

Área de Concentração:

Anatomia dos Animais Domésticos e Silvestres

Orientador:

Prof. Dr. Edson Aparecido Liberti

São Paulo 
Autorizo a reprodução parcial ou total desta obra, para fins acadêmicos, desde que citada a fonte.

DADOS INTERNACIONAIS DE CATALOGAÇÃO-NA-PUBLICAÇÃO

(Biblioteca Virginie Buff D’Ápice da Faculdade de Medicina Veterinária e Zootecnia da Universidade de São Paulo)

Bolina-Matos, Regina de Sousa

Efeitos da biomembrana de látex natural (Hevea brasiliensis) em pele de ratos Wistar submetidos à lesão térmica corporal por escaldamento / Regina de Sousa Bolina-Matos. - São Paulo : R. S. Bolina-Matos, 2008.

$138 \mathrm{f}$. : il.

Dissertação (mestrado) - Universidade de São Paulo. Faculdade de Medicina Veterinária e Zootecnia. Departamento de Cirurgia, 2008.

Programa de Pós-Graduação: Anatomia dos Animais Domésticos e Silvestres.

Área de concentração: Anatomia dos Animais Domésticos e Silvestres.

Orientador: Prof. Dr. Edson Aparecido Liberti.

1. Pele. 2. Queimadura. 3. Biomembrana. 4. Cicatrização. 5. Colágeno. I. Título. 


\begin{tabular}{|l|l|}
\hline UNIVERSIDADE DE SÃO PAULO \\
INSTITUTO DE CIENCIAS BIOMÉDICAS \\
Cidade Universitária “Armando de Salles Oliveira" \\
Av. Prof. Lineu Prestes, 2415- Cep- o5508-9oo São Paulo, SP - Brasil \\
Telefone :(55) (o11) 3091.7733- telefax : $(55)(011) 3091-7438$ \\
e-mail: cep@icb.usp.br"
\end{tabular}

Decl. CEEA.035/2008

\section{E C L A R A Ç Ã O}

Em adendo ao Certificado 014/03/CEEA, datado de 21.03.03 e por solicitação do Prof. Dr. Edson Aparecido Liberti, responsável pela linha de Pesquisa, autorizo a inclusão da aluna Regina de Sousa Bolina ao Projeto de Pesquisa "Características Histoquímicas das Fibras do $M$. Gastrocnêmio Medial de Ratos Wistar Desnutridos Submetidos à Lesão Térmica", uma vez que se trata de utilização da mesma espécie animal e de métodos experimentais similares ao referido certificado.

São Paulo, 29 de julho de 2008.

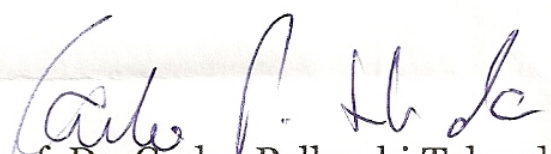

Prof. Dr. Carlos Pelleschi Taborda

Vice-Coordenador da CEEA

$\mathrm{ICB} / \mathrm{USP}$ 


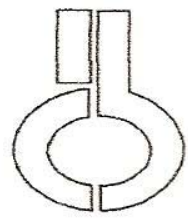

\section{CERTIFICADO}

Certificamos que o Protocolo para uso de animais em experimentação no 014/03, sobre o projeto intirulado "Características Histoquímicas das Fibras do M. Gastrocnêmio Medial de Ratos Wistar Desnutridos Submetidos à Lesão Térmica". sob a responsabilidade de Flavia de Oliveira, está de acordo com os Princípios Éticos na Experimentação Animal adotado pelo Colégio Brasileiro de Experimentação Animal (COBEA) e foi aprovado pela COMISSÃO DE ÉTICA EM EXPERIMENTAÇÃO ANIMAL (CEEA) em reunião de 21/03/2003. Prorrogada a validade.

(We certify that the protocolo $\mathrm{n}^{\circ} 014 / 03$, about "Histochemical Characterization of Muscle Fibrers of the Medial Gastrocnemius in Undernourish Wistar Rats after Body Thermal Injury" agrees with the ETHICAL PRINCIPI.ES IN ANIMAL RESEARCH adopted by Brazilian College of thimal Experimentation (COBEA) and was approved by the BIOMEDICAL SCIENCES INSTITUTE/USP-ETHICAL COMMTTEE FOR A.MIMAL RESEARCH (CEEA) in $21 / 03 / 2003$ meeting.)

São Paulo, 02 de junho de 2006.

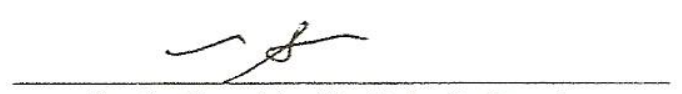

Profa. Dra. Marilia C. L. Seelaender Coordenadora da CEEA

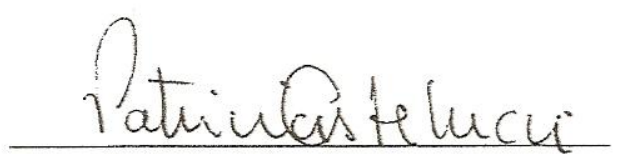

Profa. Dra. Patricia Castelucci Secretária Suplente da CEEA 


\section{FACULDADE DE MEDICINA VETERINÁRIA E ZOOTECNIA} Comissão de Bioética

\section{PARECER}

Interessado: Regina de Sousa Bolina

Assunto: protocolo adotado em experimento animal

A Comissão de Bioética da Faculdade de Medicina Veterinária e Zootecnia da Universidade de São Paulo reunida em 01 de outubro de 2008, após analisar o projeto protocolado sob o número 1451/2008, intitulado: “Efeitos da biomembrana de latéx natural (Hevea brasilensis) em pele de ratos wistar submetidos à lesão térmica por escaldamento", sob responsabilidade do Prof. Dr. Edson Aparecido Liberti (ICB), houve por bem emitir parecer favorável à realização de $10(\mathrm{dez})$ animais pertencentes ao grupo III (tratados), levando-se em consideração que as sugestões referentes à adequação da metodologia foram anotadas nesta fase do estudo. Esclarecendo que a analgesia proposta não está adequada, levando-se em consideração que os animais apresentam, frente ao procedimento experimental proposto, dor moderada. Assim sendo, deve-se associar ao Flunixin-Meglumine analgésico opióide como a morfina na dose de 2,0 $\mathrm{mg} / \mathrm{kg}$ pela via subcutânea a cada 4-6 hs.

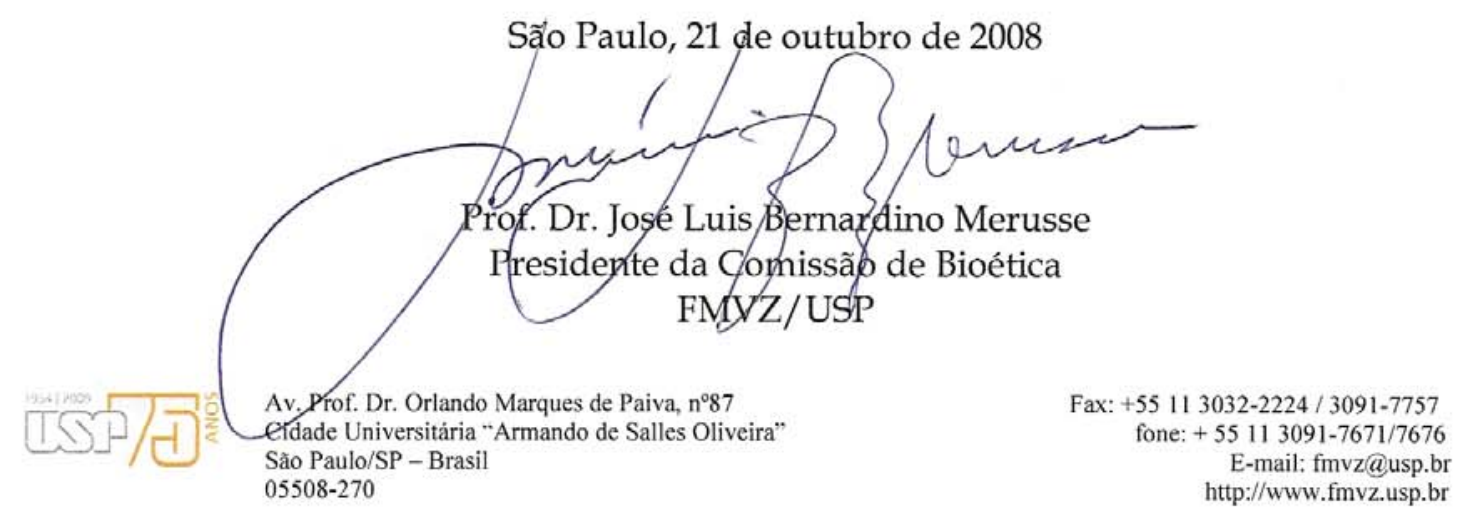




\section{FOLHA DE AVALIAÇÃO}

Nome: BOLINA-MATOS, Regina de Sousa

Título: Efeitos da biomembrana de látex natural (Hevea brasiliensis) em pele de ratos Wistar submetidos à lesão térmica corporal por escaldamento

Dissertação apresentada ao Programa de PósGraduação em Anatomia dos Animais Domésticos e Silvestres da Faculdade de Medicina Veterinária e Zootecnia da Universidade de São Paulo para obtenção do título de Mestre em Ciências

Data:

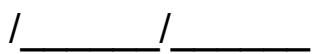

Banca Examinadora

Prof. Dr. Instituição:

Assinatura: Julgamento:

Prof. Dr. Instituição:

Assinatura: Julgamento:

Prof. Dr. Instituição:

Assinatura: Julgamento: 


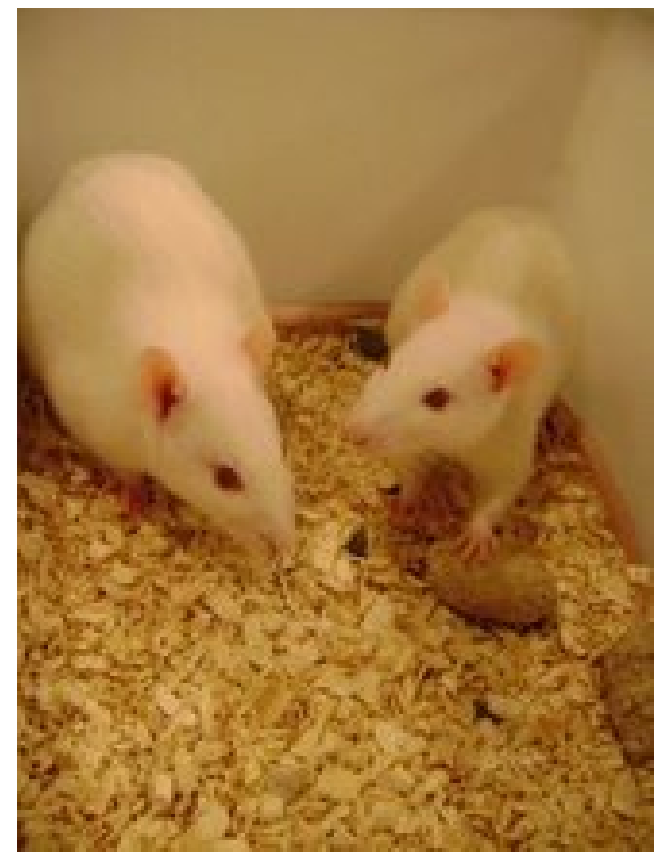

Se não fossem vocês...

Obrigada por ter nos dado a vida.

"Chegará um dia em que os homens conhecerão o intimo dos animais, $e$ neste dia, um crime contra um animal será um crime contra a humanidade". Leonardo Da Vincí

"Quando o homem aprender a respeitar até o menor ser da criação, seja animal, seja vegetal, ninguém precisará ensiná-lo a amar seu semelhante". 
Principalmente ao meu marido Paulo Henríque

E à minha famílía:

Euclides, Paulina, Daniela, Cristina, yasmim, Giovanna,

"Não há escola que se iguale a um lar decente, nem professores que se igualem a pais honestos e virtuosos". 


\section{$\mathcal{A}$ Deus}

"Confia no Deus eterno de todo o seu coração e não se apóie na sua própria inteligência. Lembre-se de Deus em tudo o que fizer, e ele the mostrará o caminho certo."

(Provérvbio. 3:5-6)

Força motriz na minha vida! Obrigada por ter aberto caminhos, possibilitando a conclusão dessa pesquisa e a obtenção de um tão sonhado titulo de $\mathcal{M E S T \mathcal { R } \text { . }}$

Sou grata a Ti por cada pessoa colocada nesse caminho durante este longo percurso e que, direta ou indiretamente, auxiliaram para a finalização desta etapa acadêmica. Sou grata também, por cada pessoa retirada desse caminho, porque se Vós escolhestes assim, é porque de fato, esta pessoa não era importante e em nada ajudaria. Agradeço-o ainda por toda evolução científica adquirida durante esta etapa, e peço que todos esses conhecimentos, somados ao seu poder, me dêem forças para continuar a percorrer um longo caminho que ainda há pela frente, um caminho novo e cheio de obstáculos com certeza.

Como és perfeito e maravilhoso, sei que Tu me escutas mesmo quando estou em profundo silêncio e, sei que Tu reconheces a sinceridade dos meus votos de agradecimento.

Obrigada Pai, porque naquele momento de desânimo me lembrei que Tu és meu Pai e peço que olhe sempre por mim, pois sou apenas um instrumento em suas mãos. 
Aos meus pais, Euclides Bolina e Paulina Bolina;

Às minhas irmãs, Daniela Bolina e Cristina Bolina;

Às minhas afithadinhas, Yasmim Bolina e Giovanna Bolina;

Aos meus cunhados, Rogérío Galvão e Raphael Pimentel;

"Que a familia comece e termine sabendo onde vai. $\mathcal{E}$ que o homem carregue nos ombros a graça de um pai. Que a mulher seja um céu de ternura, aconchego e calor. $\mathcal{E}$ que os fithos conheçam a força de onde brota o amor".

Padre Zezinho

Agradeço pela formação do substrato existente em minha essência, sendo os maiores responsáveis, aqui na terra, por esta conquista. Agradeço, sinceramente, a todo o investimento depositado em mím, abdicando, na maioria das vezes, de satisfazerem suas próprias vontades a fim de realizarem as minhas. Agradeço também pelo enorme incentivo e pelos abraços afetuosos nos momentos de chegada e também nos momentos de partida e até mesmo pelos abraços por telefone, pois estes também foram sentidos. Porém, peço desculpas pelas minhas ausências e pelas minhas intolerâncias. Enfim, gostaria de dizer que $\mathcal{A} \mathcal{M} O \mathcal{D} \mathcal{E M} \mathcal{M} I S$ TODOS VOC $\hat{E} S$ e que todas as minhas conquistas tiveram vocês por trás, pois nada foi feito sem o incentivo e o apoio de todos! Yasmim e Giovanna, vocês são uma das minhas maiores alegrias! $\mathcal{A} \mathcal{M} a d r i n h a$ ama vocês - $\mathcal{T} \mathcal{A} \mathcal{N} \mathcal{T} \tilde{\mathcal{A}} O$ ! 
Ao meu marido Paulo Henrique de $\mathcal{M}$ atos $\mathcal{A l v e s}$

"Que o amor não seja imortal, posto que é chama Mas que seja infinito enquanto dure"

Vinicius de Moraes

Aproveito a oportunidade para deixar aqui regístrado a minha admiração, consideração e agradecimento a você meu amor. Uma pessoa maravilhosa que surgiu em minha vida no inesperado, mas que muito me ensinou. Uma pessoa especial, que sempre acreditou em minha capacidade e em minha dedicação e, principalmente, confiou.

Por muitas vezes tivemos desacordos, afinal, isto é naturale importante para pessoas que se completam - absolutamente não temos que pensar e agir igualmente, porém nunca nos desrespeitamos pessoal, moral e profissionalmente. Houve sempre muito carinho, respeito e amor desde o momento em que lapidamos todas as arestas que nos impediam de caminharmos juntos para um mesmo objetivo. Sabe-se que é difícil conviver com pessoas, mas basta ter persistência, bom senso, dedicação e respeito que venceremos todas as diferenças. $\mathcal{E}$ não foi diferente na nossa convivência até aqui. Mas vencemos! Conquistamos os nossos espaços, os nossos limites, enfim, conquistamos o amor um pelo outro e hoje somos marido e mulher - e é com muito orgutho que eu digo isto! $\mathcal{E}$ assim, você permanecerá em meu coração e em minha vida para sempre! Muito obrigada por tudo meu menininho, por todas as oportunidades, por todas as palavras ditas e escritas, por todos os gestos e, finalmente, por esta dissertação - ela também é sua, meu bem! Parabéns. 
Ao grande amigo e orientador Prof. Dr. Edson Aparecido Líbertí

"O valor das coisas não está no tempo que elas duram, mas na intensidade com que acontecem. Por isso, existem momentos inesqueciveis, coisas inexplicáveis e pessoas incomparáveis"

Fernando Pessoa

Puxa-vida, esta foi a última mensagem que escreví, não porque deixeí para ser a última de propósito, mas sim, porque não encontrava palavras que conseguissem expressar meu agradecimento pela importância que você teve para a concretização de um sonho e a realização desta dissertação. Não somente pelo tempo dedicado, que foi fundamental, sem dúvida, mas também por ter aberto as portas do laboratório, por ter cedido os animais, os reagentes e os equipamentos, pela diversão, pela boa conversa e, acíma de tudo, pelo caráter e dignidade transmitidos, pelo respeito, pela compreensão e pelo amor de um pai. Obrigada por tudo, do fundo do coração e, principalmente, obrigada pela eterna amizade. Saberei agradecer sempre!

Deus, abençoe este Professor, dando-o sempre paz, saúde e felicídade. 
À Coordenadora do Programa Pós-Graduação em Anatomía dos Animais Domésticos e Silvestres e grande amiga, María Angélica Miglino

"Os desafios da vida são muitos, mas com coragem e ajuda de pessoas que nos estendam a mão, eles não se tornam barreiras, mas $o$ combustivel para a conquista".

Autor desconhecido

Houve tempos difíceis, muito difíceis eu diria, mas sempre pude contar com você (se a Senhora me permite chamá-la de você).

Houve tempos em que precísei chorar, e você me consolou. Houve tempos em que sorri por determinadas conquistas, e você sorriu comigo. Houve tempos em que bríguei, questionei e você me apoiou, brigou e questionou comigo. Houve tempos em que sonhei, futei, acreditei e vivi intensamente muitas emoções e pude dividi-las com você, e mais, você com sua amizade e presteza esteve ao meu lado, enfrentando todos os obstáculos, acreditando em mim e em meus ideais. Houve tempos em que me senti sozinha, sem esperanças e sem perspectivas, mas como um presente maravithoso de Deus, você apareceu e sempre com muita disposição. $\mathcal{E}$ hoje agradeço por todas as dificuldades as quais enfrentamos juntas, pois acredito que ganhamos muitos e bons amigos. Obrígada Professora Angélica, pela amizade, ensinamentos e apoio para trilhar este difícil caminho da pósgraduação a fim de chegar a este título de $\mathcal{M E S T} \mathcal{R E}$. 
Aos inesquecíveis mestres, Dr. César Laerte $\mathcal{N a t a l}$ e Dr. Zenon Sílva "Excelente éo mestre que, ensinando, faz nascer no espirito do discipulo um grande desejo de aprender". Rui Barbosa

Jamaís esquecerei a importância que vocês tiveram para nascer em mim a vontade de aprender e, ainda por estimular a curiosidade. Vocês sempre serão espetho e sempre serão lembrados! 
Às verdadeiras amigas Lynda Tamayo, Valquiria Mariotti e Luciana Alves

"A gente não faz amigos, reconhece-os".

Vinicius de Moraes

Amizade é mais que afinidade e envolve mais que afeição. As exigências da amizade - fraqueza, sinceridade, aceitar com a mesma seriedade as críticas e os elogios do amigo, lealdade incondicionale auxílio a ponto de um sacrífício - são estímulos para o amadurecimento moral e o enobrecimento. $\mathcal{A}$ amizade genuina requer tempo, esforço e trabalho para ser mantida. $\mathcal{A}$ amizade é algo profundo. De fato, a amizade é uma forma de amor e amor é o que sinto por vocês.

Lynda, quando crescer quero ser ígual a você - "supostamente" ter a sua disciplina e o seu equilíbrio. Acredite - você é extremamente competente e nunca deixe ninguém dizer o contrário!

Valquiria, você também é espelho - como gostaria de ser ponderada, assim como você é, a fím de lidar com fatos e situações dífíceis. "NNa verdade", aprendi ser mais otimista com a sua amizade.

Lú, quanto tempo estamos juntas, heim!? Sua calma, paciência, tranqüilídade e aceitação em casa foram fundamentaís para a finalização deste trabalho - você muito me ensinou. Obrígada pela ajuda fundamental neste último momento!

Obrigada meninas! Jamais me esquecerei da força oriunda de vocês! 
Agradecimento: Ato ou efeito de agradecer; Reconhecimento e declaração de se estar grato por algo dado ou feito por outrem;

Gratidão.

(Dicionário Houaiss da Lingua Portuguesa)

$\mathcal{A}$ todos os meus familiares (Vó, Vô, Padrinhos, Tíos e Primos), que pediram a Deus por mim e que mesmo de longe sempre se fizeram presentes.

Aos professores, funcionários e amigos do Centro Universitário de Patos de Minas pelo incentivo constante em um momento de grande decisão - vir para São Paulo e tentar.

À Faculdade de Medicina Veterináría e Zootecnia da Universidade de São Paulo, por proporcionar um desenvolvimento científico, profissional e pessoal.

À Fundação de Amparo à Pesquísa do Estado de São Paulo (FAPESP) e a esta coordenadoría pelo auxílio concedido.

Ȧ Professora Doutora María Angélica Miglino, pela oportunidade única aceitando-me como aluna do Programa de Pós-Graduação em Anatomia dos Animais Doméstícos e Sílvestres da Universidade de São Paulo, no qual desempenha importante papel de Coordenadora e pela oportunidade de crescer profissionalmente.

Aos Professores Doutores do setor de Anatomia, Francisco Javier $\mathcal{H}$. Blasquez, José Roberto Kfoury Júnior, Paula de Carvalho Papa, Pedro Primo Bombonato, Tatíana Carlesso, Carlos Eduardo Ambrósio, pelo aprendizado durante as aulas de Pós-Graduação.

À Professora Doutora Sílvía de Campos Boldrini, por sua competêncía e colaboração, pela serenidade e principalmente pelo carinho, amizade e aconselhamentos.

Ao Professor Doutor Cláudio Antônio Ferraz de Carvalho, por toda história e sabedoria transmitas. Professor, para mim foi uma grande honra tê-lo conhecido! 
Aos companheiros do Laboratório de Anatomía Funcional Aplicada à

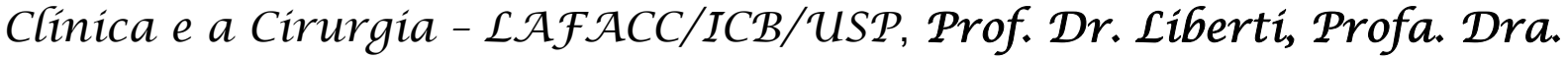
Sílvia Boldrini, Lynda Tamayo, Valquiria Mariotti, Leonardo Liberti, Willian Paganini, Paulo Alexandre Galvanini, Carlos Eduardo Seyfert, Flávia de Oliveira, Flávio Tampelini, Isabela Luques, Josemberg Baptista, Bruna Cecília Caixeta, Sabrina Caixeta, Cíbele $\mathcal{M}$ aciel, Diana $\mathcal{A}$ lves, Lucilene Ferreira, JMárcio Cristófaro, Símone Piccoli, Thiago Habacuque, Milton Siqueira, Maritza $\mathcal{A} l v e s$, Mateus Pacheco, Allan Bonani, Marcelo Cavalli, Ricardo Fontes, Karina Marques e, finalmente, meu marido Paulo Henrique, pelos ensinamentos, pelos momentos de descontração por ocasião de algumas coletas e processamento de materiais tornando o trabalho menos árduo e por todos os dias da semana que passamos juntos durante todo o tempo destinado à realização desta dissertação.

À Doutora flávía de Oliveira e ao Mestre Willian Paganini, que outrora e com muito carinho deram inicio a esta pesquisa deixando alguns resultados para que eu pudesse dar continuidade no pouco tempo que me restava. Obrigada por todas as informações e ajuda durante os procedimentos experimentais.

Ao amigo Jaime Badel pela ajuda, carinho e disponíbilidade.

Aos funcionários do Biotério do Departamento de Anatomía do Instituto de Ciências Biomédicas da Universidade de São Paulo, Ricardo Bandeira, Alessandro Rodrígo Martins, Fábio França e Renivaldo de Souza.

A Sra. Rosana Prísco, pelas avaliações quanto à estatística

Aos técnicos de laboratório do Departamento de Anatomía, Sebastião Boleta, Sônía Regina Yokomizo e MMarta María Righetti pela paciência, dedicação e auxílio com as técnicas histológicas e ultraestruturais.

Aos técnicos do Laboratório de Histopatología do Departamento de Patologia VPT/FMV VZ-USP, Luciano Bugalho e Cláudio Arroyo, pelas orientações relacionadas às colorações.

$\mathcal{A}$ toda Familia Matos, especialmente, Clêidina Matos ( $\mathcal{T}_{i}$ Lília), Cotegipe Alves ( $\mathcal{T}_{i}$ Gipinho), Kerle Cristine Leal, Luiz Filipe Leal e Valdete Leal, vocês são a minha familia de escolha e agradeço a Deus 
todos os dias por ter colocado vocês em minha vida, vocês são realmente muito importantes e apesar da distâncía, sempre estiveram muito presentes. Agradeço ainda pelo melhor presente que poderiam ter me dado - meu marido - Paulo Henríque.

Aos amigos considerados irmãos, Poliana Sousa (Poli), Rogério Luiz Matos e Willer César de Freitas (Will), vocês contribuiram com muito carinho e amizade para a finalização desta pesquisa. Obrigada pela visita e pela diversão - foi demais! Will, valeu pela ajuda com inumeros detalhes com a utilização dos programas de computador - foi fundamental e será inesquecível!

Às amigas inesqueciveis Roseâmely Angélica Barros (Nêga), Adriana Rodrigues (in memorian), Angelita Bolina, Nádia Camila Rodrigues, Luciana Isquierdo (Byllu), Aline Alves, a ajuda de vocês foi fundamental para a certeza de vir e permanecer em São Paulo.

$\mathcal{A}$ todos os amigos e colegas de Pós-Graduação deste departamento, não vou nominá-los por temor de uma omissão involuntária, porém agradeço por fazer parte integrante dos momentos passados aqui na Anatomia, por todos os momentos vividos nos laboratórios, dias de plantões e encontros, poís de uma forma direta ou indireta fizeram parte da minha vida. Im especial à grande amiga Dulcinea Teixeira, obrigada por todas as palavras de incentivo e pelo grande apoio.

$\mathcal{A}$ toda Família Marinho e Braga, especialmente, María Helena Braga (D. Lena), José Armando Braga (Sr. Mandinho), William Braga e Fábio Braga, obrigada por todos os telefonemas de apoio, ajuda e pela compreensão. Obrigada pelos almoços aos domingos em todas as vezes que estive em Minas durante o trajeto desta pesquisa, enfim, obrigada pelo carinho e por acreditar que um dia isto sería possivel.

Aos Funcionários da Biblioteca da Faculdade de Medicina Veterináría e Zootecnia da Universidade de São Paulo, pela atenção, carinho e paciêncía em nos atender sempre de bom humor.

Aos funcionários do setor de informática da Faculdade de Medicina Veterináría e Zootecnía da Universidade de São Paulo, especialmente o Valdemir Araújo (Miro) e Antonio Rodrigues (Toninho), obrigada por todas as impressões. 
Ao Comitê de Bioética do ICB-USP e da FMVZZ-USP, em especial ao Professor Doutor Jose Luis Merusse e a Professora Denise Fantoni.

Aos funcionários do ICB-USP e da FMVZ-USP, pela consideração, atenção e respeito dado durante esta minha estada neste programa de Anatomia dos Animais Domésticos e Silvestres, em especial: Maicon Barbosa, Jackeline Santana (Jackie), Fátima Minari, Tatiana Curti, Edinaldo Farias (Índio), Diogo Palermo, Ronaldo Silva, Sandra Affonso (Sandrinha), João Freitas, Raimundo Sousa, Natália Andrade (Branca), Carlos Alberto, Deyse Flexa, Claudia Lima e Joana Vasconcelos.

Aos demais funcionários por zelar pela limpeza junto ao setor da Anatomía dos Animais Domésticos e Silvestres - FMVVZ/USP.

Finalmente agradeço aos componentes da Banca de Avaliação desta Dissertação, Professores Doutores $\mathcal{E} d$ son Aparecido Liberti, Flávía de Oliveira, María Angélica Miglino, Eduardo Pompeu, Pedro Prímo Bombonato e Carlos Eduardo Ambrósio pela disponíbilidade. Muito obrigada!

\section{$\mathcal{A}$ todos aqueles que direta ou indiretamente contribuiram para a realização deste trabalho, tão importante para minha vida profissional, o meu sincero agradecimento.}

Nenhuma conquista tem significado pleno, se não for partilhada com as pessoas que os ajudaram nessa caminhada. 
Quando você deseja alguma coísa, todo o universo conspira para que seu desejo se realize.

Paulo Coelho 


\section{RESUMO}

BOLINA-MATOS, R. S. Efeitos da biomembrana de látex natural (Hevea brasiliensis) em pele de ratos Wistar submetidos à lesão térmica corporal por escaldamento. [Effects of the natural latex biomembrane (Hevea brasiliensis) in Wistar rat skin submitted to body thermal injury by scalding]. 2008. 138 f. Dissertação (Mestrado em Ciências) - Faculdade de Medicina Veterinária e Zootecnia, Universidade de São Paulo, São Paulo, 2008.

Recentemente, pesquisadores têm descrito resultados promissores oriundos da Biomembrana de Látex Natural (BML). Estudos vêm sendo desenvolvidos para comprovar as características indutoras de neovascularização e regeneração tecidual que foram atribuídas a esse material. Entretanto, a biocompatibilidade tem sido considerada um dos mais importantes itens para validar um biomaterial para sua aplicação em humanos. A proposta deste estudo foi investigar qualitativa e quantitativamente os efeitos deste biopolímero, confeccionado à partir da extração de látex vegetal oriundos da árvore da borracha, Hevea brasiliensis, em pele de ratos escaldados. Foram usados 22 ratos, Wistar machos, com pesos entre $200 \mathrm{e}$ $300 \mathrm{~g}$, divididos em três grupos: Controle negativo - normais (GI), Controle positivo queimados (GII) e Tratados com a BML (GIII). A lesão térmica foi realizada por escaldamento (LTE), padronizada pelo peso corpóreo e usando água quente $\left(85^{\circ} \mathrm{C}\right.$ for 10 segundos), e a ortoeutanásia dos animais ocorreu nos períodos de 4 e 14 dias pós-lesão. Os animais foram mantidos sob as mesmas condições de alojamento, alimentação, temperatura, umidade e luz. O grupo GIII apresentou melhor cicatrização comparado àqueles do grupo Gll. Observou-se que as fibras colágenas e elásticas apresentaram-se em uma rede melhor organizada no grupo GIII e observou-se, ainda, que o número de vasos também foi maior neste grupo. Como vistos em estudos anteriores, a BML favoreceu a cicatrização em áreas queimadas e a neoangiogênese, sugerindo que este biomaterial é um promissor recurso terapêutico para a cicatrização da pele, particularmente nos casos em que a revascularização tecidual seja importante.

Palavras-chave: Pele. Queimadura. Biomembrana. Cicatrização. Colágeno. 


\begin{abstract}
BOLINA-MATOS, R. S. Effects of the natural latex biomembrane (Hevea brasiliensis) in Wistar rat skin submitted to body thermal injury by scalding. [Efeitos da biomembrana de látex natural (Hevea brasiliensis) em pele de ratos Wistar submetidos à Lesão térmica corporal por escaldamento]. 2008. $138 \mathrm{f}$. Dissertação (Mestrado em Ciências) - Faculdade de Medicina Veterinária e Zootecnia, Universidade de São Paulo, São Paulo, 2008.
\end{abstract}

Recent investigations have described promising results obtained with the Natural Latex Biomembrane (BML). Several studies had been performed to prove the inductive characteristics of vascularization and tissue regeneration that has been attributed to this material. However biocompatibility has been considered one of the most important items to validate a biomaterial for its application in human beings. The aim of this study was to investigate qualitatively and quantitatively the effects of a biopolymer based on vegetal latex extracted from the Hevea brasiliensis rubber tree in scalded rat skin. Twenty two male Wistar rats weighing between $200-300 \mathrm{~g}$, were divided in three groups: Negative control - normal (GI), Positive control scalded (GII), and Treated with the BML (GIII). The thermal burn standardized with the body weight, was made using hot water $\left(85^{\circ} \mathrm{C}\right.$ for 10 seconds). Euthanasia was performed at 4, and 14 days pos-burn. Animals were kept under the same conditions of accommodation, feeding, temperature, humidity, and light. The burn area with satisfactory healing was greater in GIII than in GII. Collagen and elastic fibers could be seen in a very organized fashion in GIII group, in a similar arrangement that GI. The number of vessels was higher in GIII that others groups. Similar to earlier studies, the BML seemed to benefit cicatrization and neoangiogenesis in the burn skin, suggesting that this biomaterial might be a new type of therapeutic resource for skin burn replacement, especially in cases of desirable tissue revascularization.

Key word: Skin. Burn. Biomembrane. Cicatrization. Collagen. 


\section{LISTA DE ILUSTRAÇÕES}

Figura 1 - Histórico: Detalhe de uma taça de Sosias (aprox. 50 a.C.), que mostra Aquiles fazendo curativo nas feridas de Pátroclo, cena típica dos campos de batalha, onde os guerreiros tratavam mutuamente de suas feridas (Staatliche Museen, Berlim).

Figura 2 - Estrutura química da BML: Cadeias compostas por poliisoprenóis ligadas por pontes sulfurosas, proteínas oriundas do látex natural e fosfolípedes.

Figura 3 - Esquema da distribuição aleatória dos grupos 60

Figura 4 - Monitoramento dos animais: (A) Estante vertical com 12 gaiolas metabólicas, (B) Gaiola metabólica, (C) Compartimento em que foram alojados os animais.

61

Figura 5 - Período experimental (em dias) pós-lesão térmica por escaldamento (LTE) dos grupos de animais GI, GII e GIII: O dia 5 corresponde ao dia da LTE para os animais dos grupos GII e GIII. 62

Figura 6 - Biomembrana de látex natural (BML): Produto confeccionado a partir do látex natural da árvore da borracha Hevea brasiliensis...64

Figura 7 - Procedimento experimental: (A) Animal após a tricotomia do dorso e higienização da área a ser submetida à lesão. (B) Dispositivo utilizado para a realização da LTE, desenvolvido no Laboratório de Anatomia Funcional Aplicada à Clínica e à Cirurgia (LAFACC) do ICB/USP, conforme descrito por Walker e Mason (1968). (C) Animal sendo submetido à imersão em água quente. (D) Animal com o dorso queimado imediatamente após a LTE. (E, F e G) Animais dos grupos GI, GII e GIII com suturas. Observar padronização de suturas para todos os grupos. (H) Animal com as unhas intactas. (I) Animal com as unhas aparadas.

Figura 8 - Técnica do Fractionator segundo Gundersen (1986): (A) Amostra retangular total. (B) amostra seccionada no sentido do seu maior eixo, dividindo-a em duas metades. (C) Cada uma dessas metades foi subdividida em 4 partes aproximadamente iguais, a partir de seccões perpendiculares à primeira, perfazendo um total de oito fragmentos. (D) Quatro destes fragmentos foram amostrados 
aleatoriamente, de acordo com a tabela de número randômicos, para procedimento histológico. (E) Fragmentos restantes que foram destinados à microscopia eletrônica de varredura. (F) Os quatro pedaços selecionados para microscopia de luz foram cortados perperdiculares ao seu maior eixo gerando oito pedaços. (G) Cada fragmento foi verticalizado. (H) Suporte de cortiça ulitizado para montagem dos fragmentos $\mathrm{e}$, finalmente, $\mathrm{o}$ fragmento envolto por um meio de inclusão especial para congelamento de tecidos biológicos e colocado em nitrogênio líquido

Figura 9 - Procedimento histomorfométrico para avaliação da espessura do tecido de granulação (linha menor), da derme (linha média) e da espessura total do tegumento (linha maior)...................................71

Figura 10 - Procedimento estereológico da contagem de pontos para avaliação da Densidade de volume $V_{v}$ das fibras elásticas.

Figura 11 - Períodos evolutivos da LTE: No primeiro dia (A), segundo dia (B), terceiro dia (C) e quarto dia (D). No oitavo dia (E), verifica-se nos animais do grupo GIII (direita), uma área amarelo-esbranquiçada úmida (seta). As figuras $\mathbf{F}-\mathbf{H}$ representam, respectivamente, $\mathrm{O}$ aspecto evolutivo da reparação da lesão no décimo, décimo segundo e décimo quarto dias pós-LTE 76

Figura 12 - Superfície externa do tegumento dos animais do grupo GI (A, D), dos animais do grupo GII $(\mathbf{B}, \mathbf{E})$ e dos animais do grupo GIII $(\mathbf{C}, \mathbf{F})$ : Notar em (B), a crosta ressecada nos animais do grupo GII(4), diferente da superfície amarelo-esbranquiçada e umedecida presente nos animais do grupo GIII(4), tratados com a BML (C). Com 14 dias pós-LTE, tanto a crosta em Gll(14) como a camada amarelo-esbranquiçada e umedecida em GIII(14), tendem ao desprendimento..........................................................................77

Figura 13 - Superfície profunda do tegumento dos animais do grupo GI (A, D), dos animais do grupo GII $(\mathbf{B}, \mathbf{E})$ e dos animais do grupo GIII $(\mathbf{C}, \mathbf{F})$ : Notar o aspecto róseo intenso nos animais dos grupos Gll(4), GII(14) e GIII(4) (respectivamente B, E e C). Em F, a coloração intensamente avermelhada dessa região, nos animais GIII(14), tratados com a BML...................................................................78

Figura 14 - Fotomicrografias da epiderme dos animais dos grupos GI (A, B e C), GII(4) (D), GII(14) (E) GIII(4) (F), Glll(14) (G): Notar os extratos preservados em GI (camada córnea - seta maior; camada 
granulosa - seta menor, camada espinhosa - *; camada basal cabeça de seta). Nos animais Gll verifica-se uma destruição dessa camada, não sendo possível destacar os seus folhetos. Nos animais tratados com a BML (GIII) observa-se uma certa preservação dessa camada, porém sem evidenciação nítida de seus folhetos. Técnica de coloração: HE.

Figura 15 - Fotomicrografias da derme dos animais dos grupos GI (A), GII(4) (B), GII(14) (C) GIII(4) (D), GIII(14) (E): Notar os folículos pilosos e glândulas sebáceas de aspecto normal nos animais do grupo GI (setas). Nos animais dos grupos de 4 dias (GII e GIII) verifica-se glândulas sebáceas e folículos pilosos alterados (setas) bem como tecido conjuntivo desorganizado (*). Com 14 dias (GII e GIII) evidencia-se o tecido de granulação (cabeça de seta). Nos animais tratados (GIIII) nota-se, em geral, uma tendência à reorganização da derme, bem como a presença de colágeno no tecido de granulação (seta). Técnica de coloração: HE.

Figura 16 - Fotomicrografias da derme dos animais dos grupos GI (A, D e E), GII(4) (B, F), GII(14) (G), GIII(4) (C, H), GIII(14) (I): Nos animais do grupo $\mathrm{Gl}$, as fibras elásticas formam uma rede no terço superficial da derme e estão dispersas entre o tecido colágeno do terço profundo da derme. Nos animais do grupo GII(4), é nítido o adensamento das fibras elásticas no terço médio da derme. Notar, nos animais tratados com a BML (GIII), a proliferação do tecido elástico em meio ao tecido conjuntivo, principalmente no terço profundo da derme. Técnica de coloração: Verhoeff.

Figura 17 - Fotomicrografias da derme dos animais dos grupos GI (A, B; C e D), GII (E, F), GIII (G, H): Notar, em A e B, a coloração de Picrosirius sem e com luz polarizada respectivamente. Nos animais do grupo $\mathrm{GI}$, nota-se um equilíbrio entre as fibras colágenas dos tipos I e III, sendo (C), o terço superficial da derme e (D), o terço profundo. Nos animais do grupo GIl, há um predomínio das fibras colágenas do tipo I, principalmente no terço superficial da derme $(E)$, sendo $(F)$ o terço profundo. Os animais tratados com a BML (GIII) exibem um ligeiro predomínio das fibras colágenas do tipo I tanto no terço superficial $(\mathrm{G})$ quanto no terço profundo da derme (H). Técnica de coloração: Picro-sirius.

Figura 18 - Fotomicrografias do tecido de granulação dos animais dos grupos GII(14) (A, C), GIII(14) (B, D): Notar no tecido de granulação a malha regular de fibras colágenas, principalmente do tipo III, nos animais do grupo GIII, não observado nos animais do grupo GII. Técnica de coloração: Picro-sírius. 
Figura 19 - Eletromicrografias de varredura das camadas do tegumento dos animais dos grupos GI (A, B, C e F), GII (D, G) e GIII (E, H): Notar a constituição bem definida das camadas, desde a epiderme $\left(^{*}\right)$ até a camada muscular (cabeça de seta) nos animais do grupo Gl. Observar a presença de folículos pilosos (seta espessa). Nos animais do grupo Gll, apresenta fibras colágenas densamente arranjadas e, tecido de granulação com aspecto endurecido (estrela). Nos animais do grupo GIII, observar a presença de vasos sangüíneos (seta delgada).........88

Figura 20 - Representação gráfica das comparações entre as variações de peso (final - inicial) dos animais dos grupos de 4 dias $\left({ }^{*} p\right.$ $<0,05)$

Figura 21 - Representação gráfica das comparações entre as variações de peso (final - inicial) dos animais dos grupos de 14 dias $\left({ }^{*} p\right.$ $<0,05)$

Figura 22 - Representação gráfica das comparações entre as espessuras $(\mu \mathrm{m})$ da derme nos animais de quatro dias $\left({ }^{*} p<0,05\right)$.

Figura 23 - Representação gráfica das comparações entre as espessuras ( $\mu \mathrm{m})$ da derme nos animais de quatorze dias ( $\left.{ }^{*} p<0,05\right)$.

Figura 24 - Representação gráfica das comparações entre as espessuras totais do tegumento $(\mu \mathrm{m})$ nos animais de quatro dias $\left(^{*} \mathrm{p}\right.$ $<0,05)$.

Figura 25 - Representação gráfica das comparações entre as espessuras totais do tegumento $(\mu \mathrm{m})$ nos animais de quatorze dias $\left({ }^{*} \mathrm{p}\right.$ $<0,05)$.

Figura 26 - Representação gráfica da comparação entre as espessuras $(\mu \mathrm{m})$ do tecido de granulação nos animais GIl e GIII de quatorze dias $\left({ }^{*} p<0,05\right)$.

Figura 27 - Representação gráfica das comparações entre as densidades de volume $(\%)$ das fibras elásticas nos animais de quatro dias $\left({ }^{*} p\right.$ $<0,05)$ 
Figura 28 - Representação gráfica das comparações entre as densidades de volume (\%) das fibras elásticas nos animais de quatorze dias ( ${ }^{*} \mathrm{p}$ $<0,05)$

Figura 29 - Representação gráfica da comparação entre a Densidade de volume (\%) do tecido de granulação nos animais GII e GIII de quatorze dias $\left({ }^{*} p<0,05\right)$. 


\section{LISTA DE TABELAS}

Tabela 1 - Média $( \pm d p)$ da variação entre os pesos inicial e final $(g)$ dos animais dos grupos de 4 dias $\left({ }^{*} p<0,05\right)$ - São Paulo $-2008 . . . . . . .89$

Tabela 2 - Média ( $\pm \mathrm{dp}$ ) da variação entre os pesos inicial e final $(\mathrm{g})$ dos animais dos grupos de 14 dias $\left({ }^{*} p<0,05\right)$ - São Paulo - 2008.....89

Tabela 3 - Média $( \pm d p)$ das comparações entre as espessuras $(\mu \mathrm{m})$ da derme e total tegumento nos animais de quatro dias $\left({ }^{*} p<0,05\right)$ - São

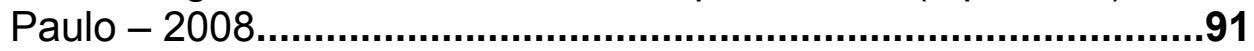

Tabela 4 - Média $( \pm d p)$ das comparações entre as espessuras $(\mu \mathrm{m})$ da derme e total tegumento nos animais de quatorze dias $\left({ }^{*} p<0,05\right)$ - São Paulo - 2008

Tabela 5 - Média $( \pm d p)$ da comparação entre as espessuras $(\mu \mathrm{m})$ do tecido de granulação dos animais dos grupos GIl e GIII de quatorze dias (* $\mathrm{p}<0,05)$ - São Paulo - 2008

Tabela 6 - Média ( $\pm \mathrm{dp}$ ) das comparações das densidades de volume (\%) das fibras elásticas dos animais de quatro dias ( $\left.{ }^{*} p<0,05\right)$ - São Paulo $-2008$

Tabela 7 - Média ( $\pm \mathrm{dp}$ ) das comparações das densidades de volume (\%) das fibras elásticas dos animais de quatorze dias $\left({ }^{*} p<0,05\right)$ - São

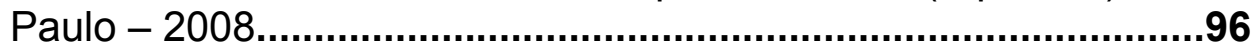

Tabela 8 - Média ( \pm dp) da avaliação da Densidade de volume (\%) do tecido de granulação dos animais dos grupos Gll e GIII de quatorze dias $14\left({ }^{*} p<0,05\right)$ - São Paulo - 2008.

Tabela 9 - Média ( $\pm \mathrm{dp}$ ) da avaliação da Densidade de volume (\%) das fibras colágenas presente no tecido de granulação dos animais do grupo GIII(14) - São Paulo - 2008 


\section{SUMÁRIO}

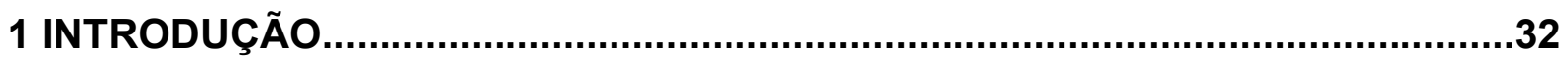

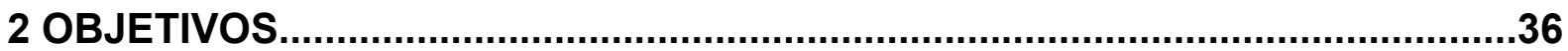

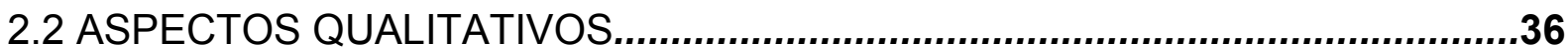

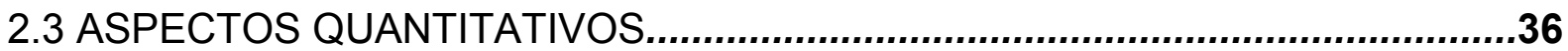

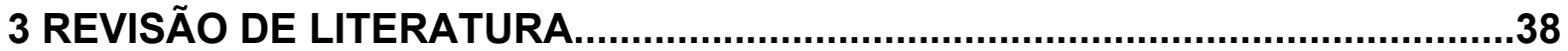

3.1 ANATOMIA E FISIOLOGIA DO SISTEMA TEGUMENTAR DE MAMÍFEROS... $\mathbf{3 8}$

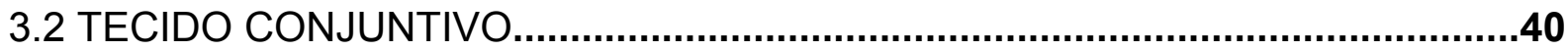

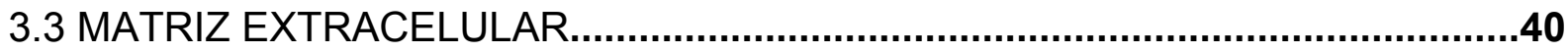

3.4 PROTEÍNAS ESTRUTURAIS FIBROSAS.......................................................

3.5 A LESÃO TÉRMICA CORPORAL POR ESCALDAMENTO (LTE) E

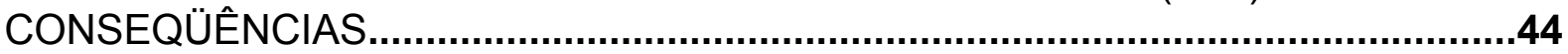

3.6 APLICAÇÕES DA BIOMEMBRANA DE LÁTEX NATURAL (BML).......................45

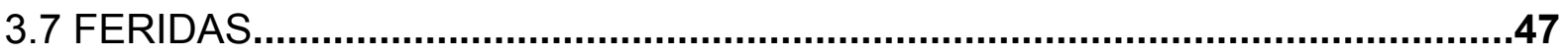

3.8 PROCESSO DE REPARAÇÃO TECIDUAL - CICATRIZAÇÃO........................... 48

3.9 ETAPAS DA REPARAÇÃO TECIDUAL..........................................................50

3.10 FATORES QUE INFLUENCIAM O PROCESSO DE REPARAÇÃO

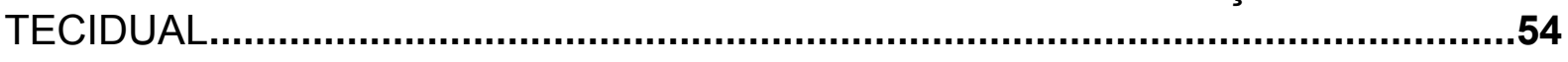

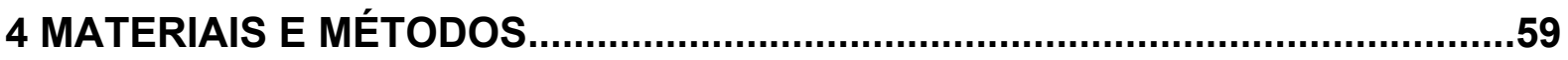

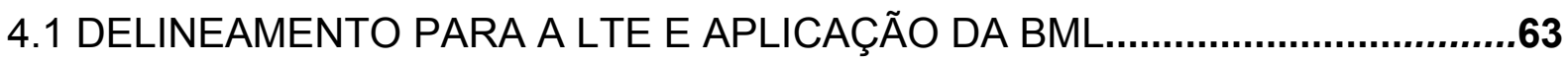

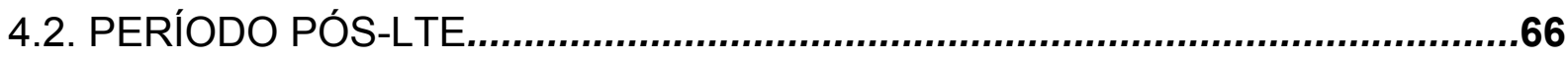

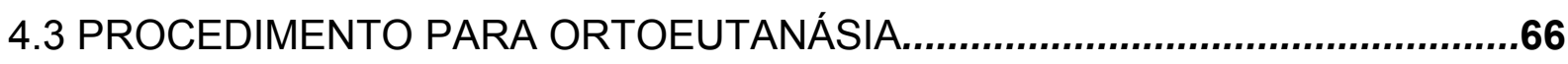

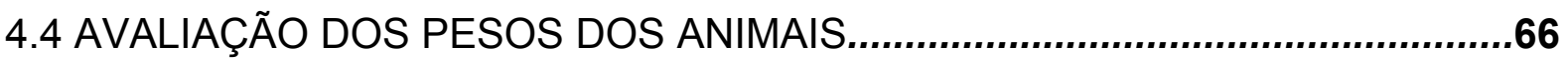

4.5 AVALIAÇÃO MACROSCÓPICA (QUALITATIVAS).........................................67

4.6 DISSECAÇÃO, INDIVIDUALIZAÇÃO E PREPARAÇÃO DAS AMOSTRAS.......67

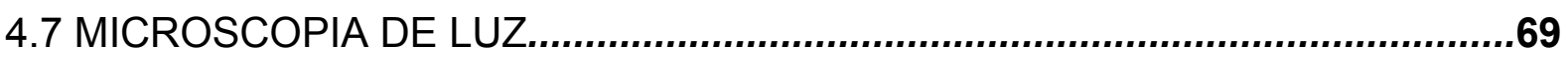

4.8 MICROSCOPIA ELETRÔNICA DE VARREDURA........................................70

4.9 ANÁLISE HISTOMORFOMÉTRICA (QUANTITATIVA)..................................70

4.10 AVALIAÇÃO ESTEREOLÓGICA (QUANTITATIVA).....................................71

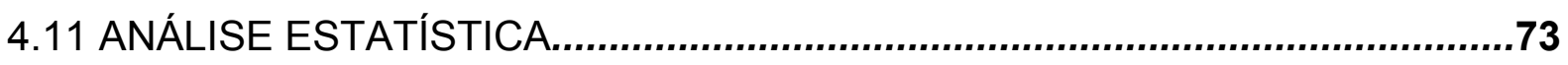

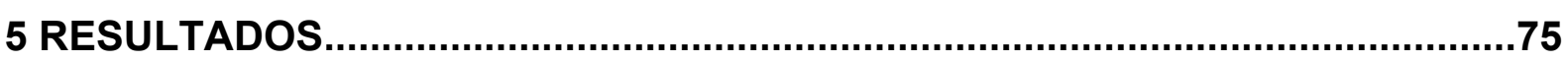

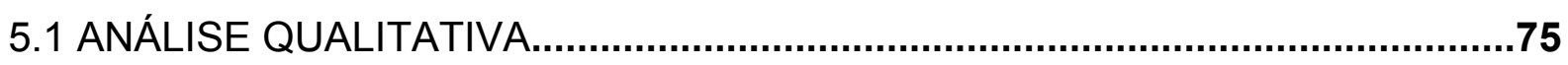

5.1.1 Aspectos macroscópicos evolutivos da área queimada...........................75 


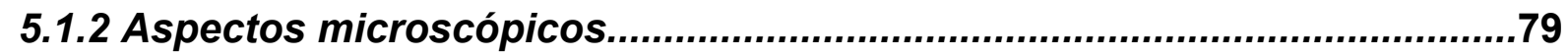

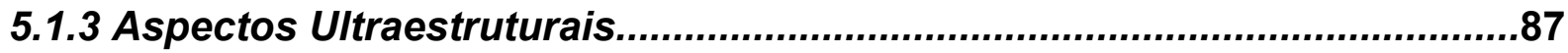

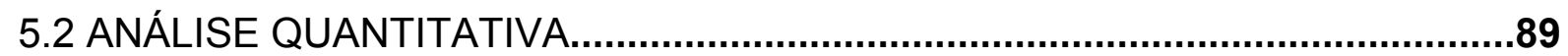

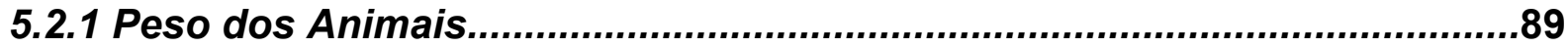

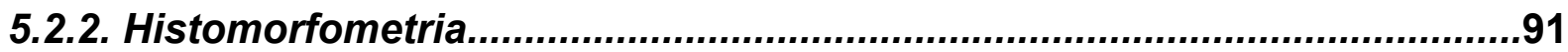

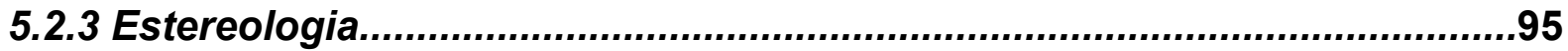

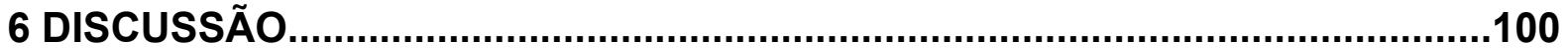

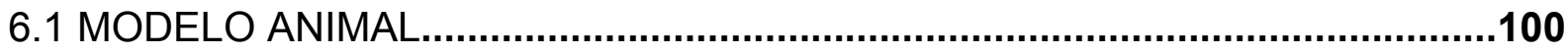

6.2 PERÍODO DE EXPOSIÇÃO À LTE E MODELO EXPERIMENTAL....................101

6.3 UTILIZAÇÃO DA BIOMEMBRANA DE LÁTEX NATURAL (BML).....................103

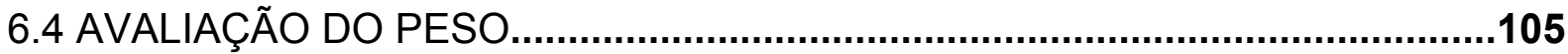

6.5 CONSIDERAÇÕES MORFOLÓGICAS.........................................................106

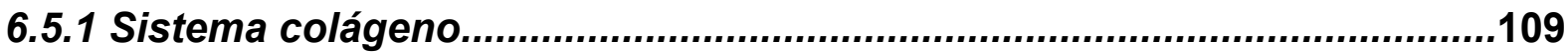

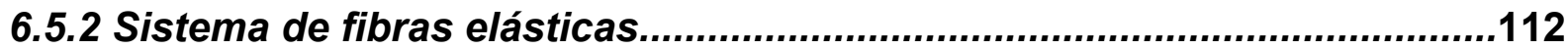

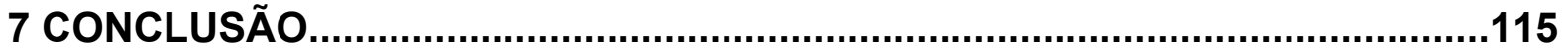

REFERÊNCIAS

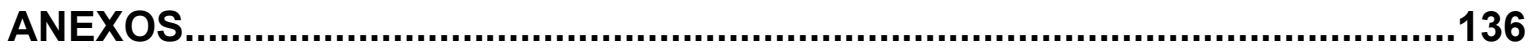




\section{INTRODUÇÃO}

As queimaduras estão entre as condições mais devastadoras encontradas na medicina (HETTIARATCHY; DZIEWULSKI, 2004) e é um problema que atinge países desenvolvidos e em desenvolvimento e que ocorre em todas as faixas etárias, desde recém-nascidos a idosos (COSTA et al., 1999). Pressupõe-se que no Brasil ocorram em torno de 1 milhão de acidentes com queimaduras por ano. Destes, 100.000 pacientes procuraram atendimento hospitalar e cerca de 2.500 falecem direta ou indiretamente de suas lesões. Estima-se que cerca de $50 \%$ de todas as vítimas de queimaduras são crianças, estando a maioria entre 0 a 6 anos de idade e cerca de $70 \%$ de todas as mortes com crianças, causadas por queimaduras, poderiam ser evitadas (OLIVEIRA et al., 2007).

As queimaduras acompanham a história do homem desde que ele aprendeu a controlar o fogo há mais de 7000 anos. Por volta de 430 a.C., Hipócrates utilizava emplastros e outras substâncias tópicas para o tratamento de queimaduras (DE LOS SANTOS GONZÁLES, 2004). Em aproximadamente 50 a.C., Aquiles era visto fazendo curativo nas feridas de Pátroclo, nos campos de batalha, onde os guerreiros tratavam mutuamente de suas feridas (Figura 1). Os egípcios concluíram que uma ferida fechada cicatrizava mais rápido do que aberta, por isso, utilizavam tiras de pano para manter unidas as margens da lesão. Hipócrates sugeria que as feridas contusas fossem tratadas com calor e pomadas para promover a supuração, remover material necrótico e reduzir a inflamação. No início da era cristã, Celsus preconizava o fechamento primário das feridas recentes e desbridamento das contaminadas para, posteriormente, poderem ser suturadas. Além disso, classificou os diferentes tipos de lesões de pele e deu detalhes do tratamento de cada uma delas (ANDRADE et al., 1992; ABLA; ISHIZUKA, 1995). Há 1300 anos, a medicina chinesa utilizava o "Yin" e "Yang", as duas forças fundamentais para descrever a evolução clínica das queimaduras (KOOP et al., 2003). Por volta de 1833, na medicina ocidental, o cirurgião escocês Sir George Bellingal descreveu a evolução clínica das queimaduras caracterizando o choque hipovolêmico, sepse, falência de múltiplos órgãos e sistemas e, ainda, resposta hipermetabólica ao trauma (HETTIARATCHY; DZIEWULSKI, 2004).

Em recém nascidos e crianças até cinco anos de idade, faixa etária de alto risco, a maioria das queimaduras ocorre por escaldamento acidental. Entre 
adolescentes e adultos jovens, a maioria ocorre por líquidos inflamáveis e, no Brasil, a literatura demonstra alta incidência de admissões hospitalares representadas por queimaduras elétricas (KAO; GARNER, 2000; OLIVEIRA et al., 2007). Em adultos a maior causa de queimaduras está relacionada aos acidentes de trabalho, e ocorrem geralmente com fogo ou eletricidade (KAO; GARNER, 2000; HETTIARATCHY; DZIEWULSKI, 2004; OLIVEIRA et al., 2007).

O tratamento das queimaduras pode ser clínico ou cirúrgico. $O$ tratamento clínico é realizado com agentes tópicos que podem ser associados a curativos oclusivos, durante o processo de reepitelização de uma lesão de espessura parcial ou, no período pré-operatório, à lesões de espessura parcial profunda e de espessura total. Os curativos podem ser sintéticos, biológicos, com ou sem agentes antimicrobianos (MERZ et al., 2003).

A Biomembrana de Látex Natural (BML) foi desenvolvida no Departamento de Bioquímica e Imunologia da Faculdade de Medicina de Ribeirão Preto da Universidade de São Paulo. Ela é confeccionada com o látex extraído da seringueira Hevea brasiliensis e, banhada com polilisina, um policátion que aumenta a permeabilidade e o fluxo microvascular. Portanto, por ser de origem vegetal, a BML não teria o potencial de transmissão de doenças infecciosas (PINHO et al., 2004). Esse material demonstrou ser biocompatível em todos os experimentos já realizados, sem nenhum tipo de reação alérgica (FORREST, 1983; MRUÉ, 2000). Isso se deve ao fato, dela ser constituída por uma cadeia de poliisoprenóis altamente purificada de proteínas. Os poliisoprenóis são naturalmente encontrados nos tecidos dos animais superiores, na forma de cadeias maiores, tais como esqualeno, ubiquinona e dolicol (LACHAT et al., 1997).

Acredita-se que a BML apresente importantes propriedades biológicas, tais como: atividade neoangiogênica, promoção de adesão celular e formação de matriz extracelular (MRUÉ, 1996; MRUÉ, 2000). Em estudos experimentais, a BML favoreceu a neoformação tecidual em camundongos, apresentando já no segundo dia um denso infiltrado inflamatório, e de 7 a 14 dias apresentou um equilíbrio no estímulo inicial da atividade inflamatória, apresentando maior número de neovasos e maior colagenase, fatores importantes na fase inflamatória da cicatrização e no recrutamento de neutrófilos para o local lesado (ANDRADE, 2007). Segundo Deleguide (2008), no início do tratamento observou-se intensa formação do tecido 
de granulação caracterizado por angiogênese e tecido colágeno, além de significativa reepitelização da ferida no período de 75 dias de tratamento.

Enfim, poucas são as doenças que trazem seqüelas tão importantes como a queimadura. Mesmo com a sobrevivência física e a ocorrência da reepitelização de toda a pele, as cicatrizes, as contraturas e a distorção da própria imagem culminam com freqüência na "morte social".

Com o avanço no tratamento para benefício de pacientes queimados novas tecnologias têm permitido uma cura mais precoce das lesões, principalmente daquelas de grandes extensões e, acredita-se que a BML pode constituir em uma nova e importante alternativa no tratamento das queimaduras. O sucesso da aplicação deste biomaterial na regeneração e cicatrização de tecidos encorajou-nos a estudar a sua eventual atuação na reconstrução do tegumento dorsal de ratos submetidos à lesão térmica corporal por escaldamento (LTE).

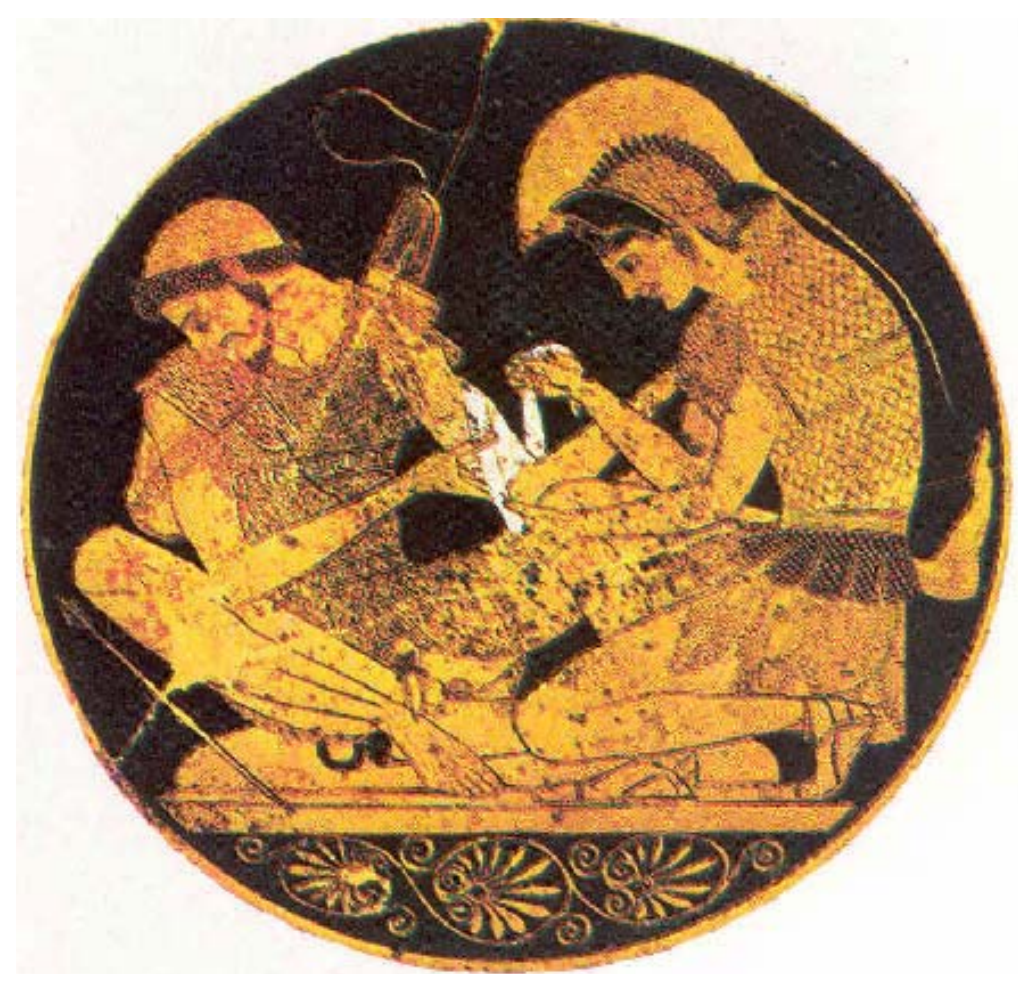

Figura 1 - Histórico ${ }^{1}$. Detalhe de uma taça de Sosias (aprox. 50 a.C.), que mostra Aquiles fazendo curativo nas feridas de Pátroclo, cena típica dos campos de batalha, onde os guerreiros tratavam mutuamente de suas feridas (Staatliche Museen, Berlim)

\footnotetext{
${ }^{1}$ Fonte: Guillen DC et al. Historia del medicamento, fascículo 2, 1987
} 


\section{OBJETIVOS}

Verificar o efeito da BML no processo de reparo, após 4 e 14 dias, do tegumento dorsal de ratos Wistar submetidos à LTE.

Para esta finalidade foram avaliados aspectos qualitativos e quantitativos.

\subsection{ASPECTOS QUALITATIVOS}

> Caracterização clínica do processo de reepitelização do ferimento causado pela LTE.

$>$ Reorganização das camadas constituintes da pele.

$>$ Avaliação do sistema de fibras elásticas e colágenas.

> Tipificação das fibras colágenas.

$>$ Caracterização do tecido de granulação.

> Indução à angiogênese pela BML.

\subsection{ASPECTOS QUANTITATIVOS}

Espessura da derme.

$>$ Espessura total do tegumento dos animais.

$>$ Espessura do tecido de granulação.

> Densidade de volume das fibras elásticas e de fibras colágenas presente no tecido de granulação. 
REVIS ̃̃O DE LITERATURA 


\section{REVISÃO DE LITERATURA}

Este capítulo dedica-se a descrição da literatura que forneceu aspectos de relevância e suporte científico para a condução desta pesquisa e está subdividida em tópicos como se segue:

\subsection{ANATOMIA E FISIOLOGIA DO SISTEMA TEGUMENTAR DE MAMÍFEROS}

A pele recobre a superfície do corpo e é o maior órgão, representando aproximadamente 16\% do peso corporal (BAL, 1996; ZHANG, 2001). Apresenta-se constituída por uma porção epitelial de origem ectodérmica, a epiderme, e uma porção conjuntiva de origem mesodérmica, a derme. A epiderme é a camada mais externa, composta por três diferentes linhagens celulares: os queratinócitos, os melanócitos e as células de Langerhans. O pigmento melanina na epiderme protege os tecidos subjacentes dos efeitos nocivos da luz ultravioleta. Dependendo da espessura da epiderme, distingui-se a pele fina e a espessa (ARNOLD et al., 1994; BAL, 1996; SANTOS, 2000; ZHANG, 2001).

A epiderme é constituída por epitélio estratificado pavimentoso queratinizado. As células mais abundantes nesse epitélio são os queratinócitos e, graças à camada queratinizada da epiderme, o organismo é protegido contra desidratação e contra o atrito, porém há outros tipos celulares como os melanócitos que secretam pigmentos, as células de Merkel que são células neuro-sensoriais e células de Langerhans que fazem parte do sistema imunológico (McGRATH et al., 1992).

Vista da derme para a superfície, a epiderme apresenta-se constituída por cinco camadas: camada basal, rica em células-tronco e também chamada de germinativa, pois apresenta intensa atividade mitótica; camada espinhosa, contém feixes de filamentos de queratina (tonofilamentos), responsáveis juntamente com os desmossomos pela manutenção entre as células da epiderme e na resistência ao atrito; camada granulosa, contém grânulos lamelares que se fundem com a membrana plasmática e expulsam seu conteúdo para o espaço intercelular, onde o material lipídico se deposita, contribuindo para a formação de uma barreira contra a 
penetração de substâncias e para tornar a pele impermeável à água, impedindo a desidratação do organismo; camada lúcida, mais evidente na pele espessa, e o citoplasma das células desta camada apresenta numerosos filamentos de queratina; e por fim, camada córnea, possui uma espessura muito variável, o citoplasma das células desta camada apresenta-se repleto de queratina (ARNOLD et al., 1994).

A descrição anterior corresponde à epiderme na sua maior complexidade, que é encontrada na pele espessa. Na pele fina, a epiderme é mais simples, faltando freqüentemente as camadas granulosa e lúcida e apresentando uma camada córnea muito reduzida. Nas regiões de pele espessa, a epiderme atinge a espessura de até 1,5 mm (ARNOLD et al., 1994; YOUNG; HEATH, 2001).

A derme é a camada mais profunda e é formada por tecido conjuntivo (ARNOLD et al., 1994; BAL, 1996; SANTOS, 2000; ZHANG, 2001). É uma camada espessa de tecido conjuntivo que se estende da epiderme até o tecido subcutâneo. Nesta camada situam-se os anexos da pele, muitos vasos sangüíneos, vasos linfáticos e nervos. Pode ser dividida em camada papilar, mais externa, e camada reticular, mais interna. A derme contém muitos tipos diferentes de células, incluindo fibroblastos e fibrócitos, macrófagos, mastócitos e leucócitos sangüíneos, particularmente neutrófilos, eosinófilos, linfócitos e monócitos (ARNOLD et al., 1994).

A camada papilar é delgada, constituída por tecido conjuntivo frouxo que formam as papilas dérmicas. Nesta camada foram descritas fibrilas especiais de colágeno, que se inserem por um lado na membrana basal e pelo outro penetram profundamente na derme. Essas fibrilas contribuem para prender a derme à epiderme. Os pequenos vasos sanguíneos, presentes nesta camada, são responsáveis pela nutrição e oxigenação da epiderme (ARNOLD et al., 1994; YOUNG; HEATH, 2001).

A camada reticular é mais espessa, constituída por tecido conjuntivo denso. Ambas as camada contêm muitas fibras do sistema elástico, responsáveis em parte, pela elasticidade da pele. Além dos vasos sanguíneos e linfáticos, e dos nervos, também são encontrados na derme as seguintes estruturas, derivadas da epiderme: folículos pilosos, glândulas sebáceas e glândulas sudoríparas (ARNOLD et al., 1994; YOUNG; HEATH, 2001).

A hipoderme é formada por tecido conjuntivo frouxo, que de uma maneira pouco firme a derme aos órgãos subjacentes. É a camada responsável pelo deslizamento da pele sobre as estruturas as quais se apóia. Dependendo da região 
e do grau de nutrição do organismo, a hipoderme poderá ter uma camada variável de tecido adiposo, que constituiu uma reserva de energia e proporciona proteção contra o frio, uma vez que a gordura é um bom isolante térmico (ARNOLD et al., 1994).

\subsection{TECIDO CONJUNTIVO}

O tecido conjuntivo desempenha as funções de sustentação, preenchimento, armazenamento, transporte, defesa e reparação. Os tecidos conjuntivos originam-se do mesênquima, que é um tecido embrionário, caracterizado por possuir células com prolongamentos, mergulhadas em abundante substância extracelular pouco viscosa. As células mesenquimais possuem núcleos ovóides e cromatina fina. $O$ mesênquima deriva principalmente do folheto embrionário médio ou mesoderme e suas células migram, envolvendo os órgãos em formação e neles penetrando. Além de dar origem aos tecidos conjuntivos, a mesoderme forma outras estruturas, como vasos sangüíneos, células do sangue e tecidos musculares (CLEARY; GIBSON, 1983).

O tecido conjuntivo apresenta diversos tipos de células separadas por abundante material extracelular. A matriz é composta por fibras e substância fundamental amorfa, constituída por um gel viscoso de macromoléculas alongadas (glicosaminoglicanas, proteoglicanas e glicoproteínas adesivas) muito hidratadas, que formam um arcabouço entrelaçado (ALBERTS et al., 1997).

\subsection{MATRIZ EXTRACELULAR}

Todos os organismos são compostos por células e por uma rede complexa de macromoléculas extracelulares denominada matriz extracelular. Esta matriz extracelular ocupa, aproximadamente, um terço ou mais do peso total do corpo. É composta por um grande número de diferentes macromoléculas secretadas 
localmente e montados em uma rede organizada, associada à superfície celular (ALBERTS et al., 1997).

Três grupos de macromoléculas associam-se fisicamente para formar a matriz extracelular: proteínas estruturais fibrosas, como os colágenos e as elastinas; um grupo distinto de glicoproteínas adesivas, incluindo fibronectina e laminina; e um gel formado de cadeias de polissacarídeos da classe glicosaminoglicanas, que são em geral encontradas ligadas covalentemente a proteínas na forma de proteoglicanas (ALBERTS et al., 1997; COTRAN et al., 2000).

A matriz extracelular desempenha importantes funções. As proteínas da matriz seqüestram moléculas como a água, para proporcionar turgor aos tecidos moles; e sais minerais, para conferir rigidez aos tecidos esqueléticos e proporcionar um reservatório para fatores de crescimento, que controlam a proliferação celular. Ainda fornece um substrato para aderência, migração e proliferação das células, podendo influenciar diretamente em sua forma e função. A degradação da matriz extracelular acompanha a morfogênese e a cicatrização de feridas, bem como a invasão e metástases tumorais (COTRAN et al., 2000). Moléculas da matriz extracelular também estão ligadas diretamente à neoangiogênese (LOCHTER; BISSELL, 1995).

\subsection{PROTEÍNAS ESTRUTURAIS FIBROSAS}

Durante o processo de evolução dos organismos, a família de um grupo de proteínas estruturais, influenciada pelo meio ambiente e pelas necessidades funcionais do organismo dos animais, modificou-se e adquiriu graus de rigidez, elasticidade e força de tensão. Estas proteínas são conhecidas coletivamente como colágeno (ARNOLD et al., 1994; YOUNG; HEATH, 2001).

As fibras de colágeno reforçam e ajudam a organizar a matriz. Os colágenos são uma família de proteínas fibrosas, encontradas em todos os animais multicelulares. Como componente principal da pele e dos ossos, eles são as proteínas mais abundantes nos mamíferos, constituindo, aproximadamente, $30 \%$ da sua massa protéica total. A característica principal de uma molécula de colágeno típica é sua estrutura longa, rígida, semelhante a uma fita helicoidal, na qual três 
cadeias polipeptídicas de colágeno, chamadas cadeias a são enroladas umas nas outras, formando um tipo de corda aparentemente torcida (LEE et al.,1999).

De acordo com sua estrutura e função, o colágeno pode ser classificado em grupos: colágenos que formam fibrilas, colágenos associados a fibrilas, colágenos que formam rede e colágenos de ancoragem. Pertencem ao grupo de colágenos que formam fibrilas os tipos I, II, III, V e XI, sendo que o colágeno tipo I é o mais abundante no corpo humano, onde ocorre como estruturas denominadas fibras colágenas, presentes em diversos órgãos, como a derme, por exemplo. (GAY; MILLER, 1978).

Nos colágenos tipos I, II e III, as moléculas de tropocolágeno se agregam em unidades microfibrilares que se juntam para formar fibrilas. Estas unidades fibrilares são reforçadas por pontes de hidrogênio, interações hidrofóbicas e ligações covalentes. As fibrilas colágenas são estruturas delgadas e alongadas, com diâmetro variável, geralmente entre 20 e 90 nm, com uma estriação transversal característica, determinada pela sobreposição das moléculas de tropocolágeno. Nos colágenos tipos I e III, as fibrilas formam fibras e no tipo I, as fibras podem formar feixes (MINOR, 1988). A síntese de colágeno é processo rápido e harmônico que tem seu inicio com uma lesão intersticial e se estende até o final da fase de cicatrização, quando ocorre a remodelação dos tecidos (ROCHKIND et al., 1989).

As fibras de tecido conjuntivo têm sido citadas como pertencendo a dois grupos, quanto à sua composição química. O primeiro grupo corresponde àquelas cujo componente estrutural é uma proteína denominada tropocolágeno. O segundo grupo de fibras do tecido conjuntivo apresenta como componente principal a elastina, uma proteína que exibe, na sua constituição molecular, cadeias de aminoácidos mostrando, em intervalos, ligações cruzadas muito semelhante às observadas na borracha (PARTRIDGE et al., 1963), embora alguns autores acreditam que o mecanismo da elasticidade dessas fibras seja, completamente, diferente do encontrado na borracha (ROSS; BORNSTEIN, 1971).

As fibras elásticas são mais delgadas que as colágenas e são formadas por microfibrilas com $10 \mathrm{~nm}$ de espessura, envolvendo parte central amorfa, e não apresentam estriação longitudinal. Ramificam-se e ligam-se umas às outras, formando uma trama muito irregular. Essas fibras cedem facilmente, mesmo às trações mínimas, porém retomam sua forma inicial tão logo cessem as forças deformantes (HEATHCOTE; GRANT, 1981; MINOR, 1988). 
O principal componente das fibras elásticas é uma glicoproteína estrutural, a elastina, que é resistente a diversas enzimas, mas pode ser digerida pela elastase secretada pelo pâncreas. A elastina também é encontrada na parede de algumas artérias como a aorta, sob a forma de lâminas perfuradas, as membranas elásticas fenestradas. A elastina constitui o material amorfo das fibras elásticas, sendo as microfibrilas formadas por várias glicoproteínas, incluindo a fibrilina (IOACHIM et al., 2002).

O sistema de fibras elásticas é composto por três tipos de fibras ligadas ao fenômeno da elastogênese. O primeiro componente formado durante elastogênese é a fibra oxitalânica, formada por microfibrilas sintetizadas e secretadas pelos fibrablastos no meio extracelular. Essas microfibrilas estão dispostas em feixes paralelos, indicando a direção e a forma da futura fibra elástica. Em seguida, pequena quantidade da substância amorfa, elastina, adere-se a essas microfibrilas, formando o segundo componente do sistema elástico: a fibra elaunínica. Com o acúmulo de maior quantidade de elastina entre as microfibrilas, a fibra se torna espessa, formando-se o terceiro componente do sistema elástico: as fibras elásticas maduras. A presença dos três componentes do sistema de fibras elásticas dos tecidos indica uma elastogênese adequada. As fibras oxitalânicas dão resistência aos tecidos, enquanto que as fibras contendo elastina proporcionam elasticidade (GAWLIK, 1965; ROSEMBLOOM, et al., 1993). A quantidade dos três tipos de fibras é variável nos diferentes tecidos e parece depender da função e do processo de envelhecimento (RODRIGUES et al., 1990, RODRIGUES et al., 1999).

As fibras são vistas ao microscópio eletrônico como um feixe axial de fibrilas embebidas em material amorfo, revestindo o conjuntivo e fibrilas tubulares com disposição espiralada, o que está de acordo com experiências com luz polarizada realizada por Denkhaus (ROSS e GREENLEE, 1966). As principais células produtoras de elastina são os fibroblastos e as células musculares lisas dos vasos sangüíneos (CLEARY; GIBSON, 1983; KRSTIC, 1984; SERGEI, 2002). 


\subsection{A LESÃO TÉRMICA CORPORAL POR ESCALDAMENTO (LTE) E CONSEQÜÊNCIAS}

Uma característica marcante da lesão térmica é a ampla destruição de tecidos, o que leva a uma ativação de processos catabólicos pelo organismo, a fim de reparar a área afetada. A resposta hipermetabólica para o trauma, causado por queimadura severa e sepse, está associada ao aumento da energia consumida e ao substrato energético liberado das reservas de proteína e de gordura do organismo (OLIVEIRA, 2006). O desenvolvimento de um edema e um progressivo dano vascular são características de ferimentos por queimaduras (WILLIAMS, 2002).

As lesões causadas por queimaduras podem ser classificadas quanto à profundidade. A Sociedade Brasileira de Queimaduras (SBQ) divide as lesões em três grupos: espessura parcial superficial ( $1^{\circ}$ grau), quando a lesão atinge apenas a epiderme e as camadas superficiais da derme; espessura parcial profunda $\left(2^{\circ} \mathrm{grau}\right)$, quando a mesma atinge camadas profundas da derme; e espessura total ( $\left.3^{\circ} \mathrm{grau}\right)$, quando a lesão é profunda o bastante para atingir além do tecido subcutâneo (JANZEKOVIC, 1970; GOMES et al., 2000; MERZ et al., 2003). Essa classificação torna-se primordial quanto à tomada de decisão na hora de instituir uma terapêutica adequada (JANZEKOVIC, 1970; GOMES et al., 2000).

A pele é o local onde a maior parte da lesão fica delimitada, pois ela serve de barreira à transferência de energia para tecidos mais profundos. Ela sofre lesões decorrentes do calor pelo contato direto e pela isquemia progressiva causada pela lesão. A destruição tecidual está relacionada com a temperatura e com o tempo de exposição e o dano celular direto resulta da desnaturação protéica. O suprimento sanguíneo e as condições da lesão são importantes na resposta celular final (WOLF; HERNDON, 2002; MERZ et al., 2003).

Jackson descreveu as três zonas concêntricas de lesão térmica como: zona de coagulação - zona central, irremediavelmente lesada pelo trauma devido ao contato direto com a fonte de calor; zona de estase - área em torno da zona de coagulação, composta por células lesadas que, em situações ideais, possuem a capacidade de se regenerar; e a zona de hiperêmica - caracterizada pela vasodilatação decorrente do processo inflamatório, onde as células se regeneram, 
normalmente, em um período de 7 a 10 dias, caso não ocorra nenhum outro insulto (WOLF, HERNDON, 2002; MERZ et al., 2003).

Além disso, lesões no nível da derme papilar, ou acima desta, poderão recuperar-se espontaneamente, se as condições oferecidas no tratamento forem adequadas. Geralmente, estas lesões se recuperam sem a ocorrência de cicatrizes patológicas ou contração, entretanto podem produzir áreas com alteração da pigmentação (DEITCH et al., 1983). Por outro lado, lesões que atingem o nível da derme reticular e/ou mais profundamente, não apresentam possibilidade de regeneração espontânea e devem ser removidas e cobertas com algum substituto cutâneo ou fechadas com a própria pele do paciente. A lesão da derme reticular frequentemente leva a extensa cicatrização, limitação funcional e infecção, tornando essencial a remoção precoce de tais lesões e sua cobertura e/ou fechamento imediato (HUNT; SATA, 1982).

Em queimaduras cutâneas, a área afetada está relacionada à elevação da taxa metabólica. Isto sugere que o fator metabólico termo-regulador, causado por deterioração ou perda da barreira de resfriamento evaporativo cutâneo normal, também contribui para o hipermetabolismo, embora a sua ação precisa, não tenha sido estudada (DOWNEY et al., 1986). De fato, para Clowers et al. (1983) e Baracos et al. (1983) pacientes queimados exibem um período de hipermetabolismo, o qual se estende do $9^{\circ}$ para $012^{\circ}$ dia pós-lesão térmica, sendo o seu grau proporcional à extensão e severidade do ferimento.

A resposta imune e metabólica ao trauma provocado por uma queimadura pode levar a um processo de cicatrização com hipertrofias e contraturas (COSTA et al., 1994). Além disso, a grande necessidade de reparação do tecido queimado pode levar à perda da função do órgão acometido (ROSSI et al., 1998)

\subsection{APLICAÇÕES DA BIOMEMBRANA DE LÁTEX NATURAL (BML)}

O látex natural é a seiva retirada da seringueira (Hevea brasiliensis) que tribos indígenas da Amazônia utilizavam-na em seu estado natural, de forma empírica, para curar feridas de pele. Pesquisadores observaram que o látex é um cicatrizante e uma defesa natural da planta. Próteses desse material foram desenvolvidas na 
Universidade de São Paulo - USP em que a BML foi utilizada, com sucesso, na reconstrução do esôfago de cães, sendo eliminada após dez dias de pós-operatório nas fezes dos animais (MRUÉ, 1996).

O processo de fabricação é muito simples. O látex natural é coletado da árvore da borracha usando somente amônia como preservativo. Então, este látex coletado é centrifugado e suas proteínas são reduzidas, principalmente aquelas com potencial para causar alergias. Uma composição sulfurada (Figura 2) é adicionada como o único agente curador. Após a polimerização do látex em baixas temperaturas em um molde de vidro, o processo resulta em uma biomembrana. Finalmente o produto é esterilizado pelo método do óxido etileno (MRUÉ et al., 2004).

O látex natural da seringueira se comporta induzindo a formação de uma base de tecido conjuntivo/fibroso, capaz de suportar o conteúdo abdominal, mas não se incorpora aos tecidos receptores, sendo eliminado, aproximadamente, aos 14 dias após a sua implantação (AZÔR, 2004; PAULO et al., 2004), foi ainda empregado para herniorrafia em bezerras portadoras de hérnias umbilicais e neste não houve eliminação do material (RABELO et al., 2004). Todas as propriedades atribuídas ao látex natural da seringueira têm sido atribuídas à presença de um possível fator de crescimento na sua composição, que atuaria promovendo a neovascularização, adesão celular e formação de matriz extracelular (FRADE et al., 2001; OLIVEIRA et al., 2003).

O primeiro trabalho, utilizando este material, na reconstrução de defeitos experimentais foi no esôfago de cães, e demonstrou influência da prótese na neoformação tecidual, sugerindo a possibilidade do seu uso como substituto ou promotor da formação de órgãos e tecidos, embora tenha havido eliminação do material (MRUÉ, 2000). A BML foi também utilizada, com grande sucesso, para substituição parcial do pericárdio de cães (SADER, 2000), tratamento de úlceras flebopáticas no homem (FRADE, 2001), arterioplastia experimental no cão (FREITAS, 2001), meringoplastia (OLIVEIRA, 2003), indutor da cicatrização conjuntival em coelhos (PINHO, 2004) e efetivo método para cobertura da cavidade mastóidea, facilitando epitelização e renovação desta cobertura (SOUSA, 2007). 


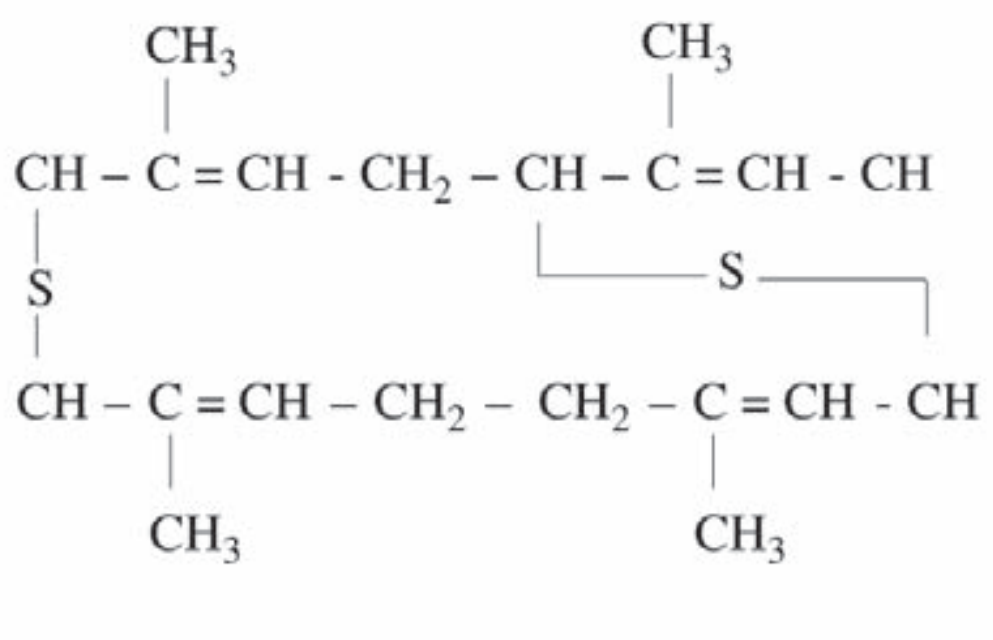

Figura 2 - Estrutura química da $\mathrm{BML}^{2}$. Cadeias compostas por poliisoprenóis ligadas por pontes sulfurosas, proteínas oriundas do látex natural e fosfolípedes

\subsection{FERIDAS}

Uma ferida é representada pela interrupção da continuidade de um tecido corpóreo, em maior ou em menor extensão, causada por qualquer tipo de trauma físico, químico, mecânico ou desencadeada por uma afecção clínica, que aciona as frentes de defesa orgânica para o contra-ataque (CESARETTI, 1998).

Sua classificação constitui importante forma de sistematização, necessária para o processo de avaliação e registro. Assim, as feridas podem ser classificadas, de acordo com o tempo de reparação tecidual, em agudas e crônicas. As feridas agudas são originadas de cirurgias ou traumas e a reparação ocorre em tempo adequado, sem complicações. As feridas crônicas são aquelas que não são reparadas em tempo esperado e apresentam complicações (SANTOS, 2000).

Outra classificação refere às estruturas comprometidas, e consiste na descrição anatômica da profundidade da ferida. Este sistema é adotado para estadiar alguns tipos de feridas crônicas, como as úlceras por pressão e as queimaduras. O sistema de classificação por extensão do dano tecidual completa o sistema de classificação de acordo com o tempo de regeneração. Desta forma,

\footnotetext{
${ }^{2}$ Mrué et al., Evaluation of The Biocompatibility of a New Biomembrane. Materials Research, v. 7, n.2, p. 277-283, 2004.
} 
observa-se a ferida superficial (limitada à epiderme), a ferida com perda parcial (limitada à epiderme e porção superior da derme) e a ferida com perda total (onde se observa destruição da epiderme, derme, tecido subcutâneo, podendo invadir músculos, tendões e ossos) (BRYANT, 1992; SANTOS, 2000).

\subsection{PROCESSO DE REPARAÇÃO TECIDUAL - CICATRIZAÇÃO}

O processo de reparação tecidual compreende dois mecanismos de restauração dos tecidos: a regeneração e a cicatrização.

A regeneração ocorre com reposição tecidual "original". O trauma inicial gera uma resposta inflamatória aguda, manifesta através de edema e formação de exsudato seroso, rico em leucócitos, que cessa em menos de 24 horas. As células epidérmicas, das margens da ferida e das invaginações epidérmicas dos folículos pilosos e glândulas sudoríparas e sebáceas começam a proliferar e migrar no leito da ferida, ocluindo rapidamente sua superfície (ABLA; ISHIZUKA, 1995; SANTOS, 2000).

A cicatrização visa à restauração dos tecidos lesados, a fim de preservar suas funções (FINE; MUSTOE, 2001).

O processo de cicatrização de feridas é composto de uma série de estágios complexos, interdependentes e simultâneos, que são descritos em fases (THOMAS et al., 1995; CESARETTI, 1998; SANTOS, 2000), alguns dos quais continuam por muitos anos após o restabelecimento da integridade física do tecido lesado (WEISSMAN, 1992).

Segundo Weissman (1992) Para a pele caracterizam-se três tipos principais de lesões:

a) lesão superficial: quando atinge somente o epitélio sem comprometer a camada basal da derme, existe epitelização por deslocamento das células sem resultar em cicatriz;

b) lesão profunda: constituída por ferida incisa limpa, com perda inapreciável de tecido, mínima hemorragia, ausência de infecção e com bordas bem justapostas;

c) lesão aberta: com perda de substância, com ou sem infecção, bordas irregulares com ou sem justaposição, havendo preenchimento do espaço por uma massa de 
vasos e células neoformadas que constitui o tecido de granulação com posterior reorganização e conversão em tecido fibroso.

Há uma grande variabilidade na regeneração, dependendo de fatores locais e sistêmicos, como fatores do hospedeiro, fatores locais e fatores externos. Embora o tipo de ferimento, o tempo de evolução, o órgão ou tecido envolvido e as técnicas utilizadas interfiram na cicatrização, o processo é basicamente o mesmo. Este processo ocorre em todo o organismo. Em termos clínicos, pode ser classificada em primeira, segunda ou terceira intenção (DOUGHTY, 1992; DEALEY, 1996; COTRAN et al., 2000; BORGES et al., 2001).

a) primeira intenção: quando os bordos são deixados unidos ou quando não há perda de tecido e as extremidades da pele ficam justapostas uma à outra;

b) segunda intenção: quando não é possível unir os bordos, o próprio organismo preenche o espaço necessário à cicatrização. Ocorre em feridas onde houve perda de tecido e as extremidades da pele ficam distantes umas das outras, sendo necessária a formação de tecido de granulação até que a contração e epitelização aconteçam;

c) terceira intenção: está evoluindo por segunda intenção e, então, sutura-se para ajudar, ou seja, a ferida é deixada aberta por um determinado período, funcionando como cicatrização por segunda intenção, sendo suturada posteriormente, como cicatrização por primeira intenção. Este procedimento é empregado geralmente nas feridas cirúrgicas com infecção, porém, não é considerada de primeira nem segunda intenção.

A cicatrização por primeira intenção é a mais rápida e forma cicatrizes menores, visto que a fenda da ferida é mais estreita e a destruição tecidual nas suas bordas é menor. O exemplo clássico é o das feridas cirúrgicas (WEISSMAN, 1992).

As cicatrizes hipertróficas e queloidianas são bastante freqüentes e são constituídas por neoplasias benignas do tecido cicatricial, decorrentes de uma proliferação do tecido de granulação na fase produtiva ou assimilativa. O quelóide difere da cicatriz hipertrófica por ultrapassar os limites dos tecidos normais e pela presença de fibras colágenas hialinizadas. Microscopicamente os dois casos são semelhantes: as fibras colágenas são irregulares, grossas, e formam feixes distribuídos ao acaso, contendo capilares e fibroblastos em maior número do que uma cicatriz normal (SPRINGER, 1994). 


\subsection{ETAPAS DA REPARAÇÃO TECIDUAL}

Do ponto de vista morfológico, identificam-se três fases consecutivas, havendo um dinamismo com sobreposição entre elas (THOMAS et al., 1995; CESARETTI, 1998; SANTOS, 2000).

$\mathrm{Na}$ primeira fase da cicatrização, ou fase inflamatória, os principais eventos são: hemostasia, quimiotaxia leucocitária e diapedese, fagocitose e liberação de fatores de crescimento. A segunda fase, ou fase de proliferação celular é dividida em outros três eventos: angiogênese, proliferação fibroblástica e epitelização (KOHN, 1992; THOMAS et al., 1995). Na terceira fase conhecida como formação do tecido conjuntivo, continua-se formando o tecido de granulação, sendo sua principal característica a presença de fibroblastos, que produzem matriz extracelular, colágeno e glicosaminoglicanos. A quarta fase, ou fase da contração, caracteriza se pela aproximação das bordas da ferida pela movimentação das mesmas através dos miofibroblastos. A quinta fase, chamada de remodelação, é basicamente descrita por modificações no tecido conjuntivo, principalmente na matriz extracelular, como o aumento na resistência entre as fibras colágenas, ação das colagenases e diminuição da quantidade de água, devido à diminuição de proteoglicanos e da vascularização (SPRINGER, 1994; THOMAS et al., 1995).

Fase inflamatória - Celsus, escritor romano do primeiro século d.C., enumerou quatro sinais cardeais da inflamação: rubor, tumor, calor e dor (COTRAN et al., 2000). Virchow acrescentou um quinto sinal clínico: perda de função (COTRAN, 1993).

O tecido conjuntivo vascularizado, inclusive plasma, células circulantes, vasos sangüíneos e componentes extravasculares, diante de estímulos endógenos ou exógenos, pode desencadear uma reação complexa denominada de inflamação, que é caracterizada como uma reação dos vasos sangüíneos, que conduz um acúmulo de líquido e de leucócitos ao tecido extracelular (SPRINGER, 1994). A inflamação atua no sentido de bloquear, diluir ou destruir o agente agressor, substituindo tecido agredido pela regeneração das células parenquimatosas nativas e pelo preenchimento de tecido fibroblástico, reconstituindo e cicatrizando o tecido lesado (MAJNO, 1992). 
Juntamente com todas estas alterações, que correspondem a resposta vascular, existe uma resposta celular. Algumas células são importantes nesta fase: os neutrófilos são responsáveis pela digestão de bactérias e tecidos desvitalizados e os monócitos transformam-se em macrófagos e auxiliam na fagocitose de bactérias e restos celulares. Após o trauma, são liberados mediadores celulares, os quais estimulam a elaboração de substâncias, que desenvolvem o fenômeno inflamatório (histamina, serotonina, bradicinina, prostaglandinas e tromboxanes, linfocinas, interleucina 1 e 2). O fator de crescimento é liberado pelas células epidérmicas e plaquetas. Inúmeros fatores de crescimento e mediadores têm sido estudados e, ainda, sua influência na cicatrização de feridas (ABLA; ISHIZUKA, 1995).

A inflamação é dividida em padrões agudo e crônico. A inflamação aguda é a resposta imediata e inicial a um agente agressor, tem duração relativamente curta e tem como características principais a exsudação de líquidos e de proteínas plasmáticas e a migração de leucócitos, principalmente neutrófilos. Para que os leucócitos possam alcançar o interstício, é preciso que haja adesão ao endotélio e transmigração, conhecida como diapedese (SPRINGER, 1994).

Os fenômenos vasculares na inflamação aguda caracterizam-se pela dilatação arteriolar e abertura de leitos capilares, resultando em um aumento do fluxo sangüíneo para a região agredida, e este aumento de líquido extravascular rico em proteínas constitui o exsudato (WEISSMAN, 1992).

A inflamação crônica tem longa duração, e ao contrário da aguda que se manifesta por alterações vasculares, edema e infiltração basicamente neutrofílica, caracteriza-se por infiltração de células mononucleares que incluem macrófagos, linfócitos e plasmócitos, destruição tecidual, proliferação de pequenos vasos sangüíneos e fibrose (MAJNO, 1992).

A fase inflamatória inicia-se imediatamente após a injúria. Quando ocorre o ferimento, a lesão dos vasos produz sangramento, e a resposta do organismo frente a esse evento é a hemostasia, que se traduz por vasoconstrição e formação de coágulo (FINE; MUSTOE, 2001; YOUNG, 2001). O coágulo auxilia na aproximação das bordas lesadas e na formação de uma matriz, na qual fibroblastos, células endoteliais e queratinócitos podem ingressar (HOM, 1993).

Após a parada do sangramento ocorre vasodilatação, mediada por várias substâncias, como a histamina e serotonina, bradicinina, prostaglandinas e óxido nítrico, que permite um aumento do fluxo sangüíneo para a área do ferimento, 
causando calor e rubor, levando mais nutrientes, células reparadoras e oxigênio para o interstício, aumentando sua pressão osmótica. A vasodilatação aumenta a pressão hidrostática, levando a uma fuga de líquidos para o meio extravascular. A associação desses fenômenos leva ao edema local (FINE; MUSTOE, 2001).

Dois dias após a lesão, há um grande afluxo de neutrófilos para a ferida, a qual se encontra com tecido desvitalizado, coágulo, bactérias e proteínas séricas extravasadas. Os neutrófilos são os responsáveis pelo desbridamento das superfícies da ferida e de tecidos desvitalizados, fagocitose de partículas antigênicas e de corpos estranhos e, ainda, liberação de grânulos para a rede de fibrina, provocando hidrólise enzimática da matriz extracelular. Todos esses eventos visam a promoção da limpeza da área lesada e o início da fase seguinte (SPRINGER, 1994; WITTE; BARBUL, 1997; FINE; MUSTOE, 2001).

Durante os dois ou três dias seguintes, as células predominantes são os macrófagos, os quais são provenientes da migração e diapedese dos monócitos circulantes ou são residentes do próprio tecido (FINE; MUSTOE, 2001).

Linfócitos também aparecem no local da lesão, mas em número pequeno. Acredita-se que os linfócitos estejam relacionados aos processos inflamatórios crônicos (FINE; MUSTOE, 2001).

Fase de proliferação celular: nesta fase ocorre a reparação do tecido conjuntivo e do epitélio (ABLA; ISHIZUKA, 1995).

Na reparação do tecido conjuntivo ocorre a formação do tecido de granulação, com proliferação endotelial e fibroblastos. O fibroblasto surge por volta do segundo e do terceiro dia após o trauma, sendo uma célula fusiforme, com núcleo oval, de origem controversa. O fibrinogênio do exsudato inflamatório transforma-se em fibrina, formando uma rede, onde os fibroblastos depositam-se e passam a multiplicar-se e a secretar os componentes protéicos do tecido cicatricial. Concomitante a esta fibroplasia, ocorre intensa proliferação vascular. Este tecido formado por fibroblastos, substâncias produzidas por eles e vasos sangüíneos é denominado tecido de granulação, clinicamente apresentando-se com aspecto granuloso e avermelhado. O miofibroblasto é uma célula que está presente no tecido de granulação e confere capacidade contrátil, reduzindo a área cruenta e facilitando a epitelização. A atividade mitótica do fibroblasto praticamente desaparece em torno do $15^{\circ}$ dia. Estes passam a secretar as proteínas presentes no tecido de granulação, 
produzindo componentes da substância fundamental e colágeno (ABLA; ISHIZUKA, 1995).

A epitelização é importante, pois o epitélio oferecerá ao organismo uma dupla proteção: a partir do meio interno, contra as perdas de fluidos, eletrólitos e proteínas, e a partir do meio ambiente, contra a penetração de agentes infecciosos (WITTE; BARBUL, 1997). Na pele, a epiderme espessa-se e, as células basais da borda da ferida aumentam de tamanho e migram para a mesma, não se dividindo até ser restaurada a continuidade epidérmica. A migração é influenciada pelo tipo de matriz, tensão de oxigênio e presença ou não de infecção. As células basais fixas em uma zona próxima à borda cortada da ferida continuam a se dividir, e suas células-filhas achatam-se e migram sobre a matriz da ferida como uma lâmina. Essa proliferação celular iniciada após a migração é máxima 48-72 h após a lesão. O estágio final da reepitelização é a maturação das células epidérmicas. Em torno do décimo dia há um estrato córneo, que, comumente, é mais espesso que o da pele sã circunjacente (YOUNG, 2001).

Formação de tecido conjuntivo: a formação do tecido de granulação se inicia no terceiro ou quarto dia após a injúria tecidual e é mantida até que a reepitelização esteja completada. O fibroblasto produz o colágeno fibrilar, sintetiza elastina, fibronectinas, glicosaminoglicanas e proteases, como a colagenase, importante para o desbridamento e o remodelamento (VAN WINKLE, 1967).

A fibronectina é importante para o ingresso dos fibroblastos por funcionar não apenas como um quimioatraente, mas também, quando entrelaçado à fibrina como um suporte adesivo sobre o qual o miofibroblasto possa se acoplar, via um mecanismo de receptores específicos, migrar e, subseqüentemente, sintetizar o colágeno (CLARK et al., 1983).

As glicosaminoglicanas não apenas auxiliam na manutenção da hidratação da ferida, mas também podem conduzir a migração e à proliferação celular na ferida (BALAAS; HOLMGREN, 1950).

Nos estágios tardios da formação do tecido de granulação, o ácido hialurônico é substituído por proteoglicanas. Evidências sugerem que as proteoglicanas possam ser importantes contribuidoras à resistência tecidual e desenvolverem algum papel na regulação da síntese de colágeno. Tendem a estabilizar a adesão célula-matriz, 
desencorajando a migração celular ao longo da estrutura de fibronectina (WOOD, 1960; LARK et al., 1985).

Fase de contração: entende-se por contração da ferida, o processo em que, feridas abertas fecham por movimento das margens em direção ao centro, cerca de quatro dias após a interrupção da integridade da pele (WITTE; BARBUL, 1997). A velocidade de contração da ferida não é a mesma em todos os pontos e o restabelecimento da integridade física não constitui um estímulo que faça cessar a contração. Descartou-se a idéia de que a desidratação do tecido seja responsável pela contração, e de que a síntese do colágeno e a contração da ferida poderiam ser os responsáveis pela aproximação e união das bordas da ferida. O mecanismo de contração que diminui a lesão é gerado por forças celulares e elementos contráteis de fibroblastos e miofibroblastos com uma reorganização concomitante do citoesqueleto (COHN, 1978).

Fase de remodelação: nesta fase ocorrem dois eventos importantes: deposição, agrupamento e remodelação do colágeno e regressão endotelial. A remodelação do colágeno inicia-se na formação do tecido de granulação e mantémse por meses após a reepitelização. As colagenases e outras proteases produzidas por macrófagos e células epidérmicas dão direção correta às fibras colágenas difusas. Há diminuição de todos os elementos celulares, inclusive fibroblastos, bem como dos elementos do tecido conjuntivo. A regressão endotelial ocorre através da diminuição progressiva de vasos neoformados, clinicamente a cicatriz se torna menos espessa, passando de uma coloração rosada para esbranquiçada (ABLA; ISHIZUKA, 1995).

\subsection{FATORES QUE INFLUENCIAM O PROCESSO DE REPARAÇÃO TECIDUAL}

Alguns fatores podem afetar o processo de reparação tecidual, são chamados de sistêmicos e locais. Entre os fatores sistêmicos destaca-se: a idade, a imobilidade, o estado nutricional, doenças associadas e o uso de medicamentos contínuos, principalmente as drogas imunossupressoras. Esses fatores muitas vezes 
não podem ser eliminados, mas devem ser controlados. Os fatores locais são: a localização anatômica da ferida, a presença de infecção, tecido desvitalizado entre outros, e são fundamentais na escolha do tratamento local (BRYANT, 1992; SANTOS, 2000).

Eventos que ocorrem próximos ou sobre a cicatrização de feridas, como técnica cirúrgica, formação de hematomas, reação de corpo estranho, radioterapia, condições de base e dessecação, podem ter grande influência no grau de cicatrização (SAARIALHO-KERE et al., 1992).

Idade: é um dos aspectos sistêmicos mais importantes, como co-fator de risco tanto para a lesão como para a sua manutenção, ao gerar um impacto no funcionamento de todos os sistemas fisiológicos corporais. A idade avançada está associada a uma série de alterações nutricionais, metabólicas, vasculares e imunológicas e, muitas vezes, as doenças crônicas, que tornam o indivíduo mais suscetível ao trauma e à infecção (SANTOS, 2000).

Estado Nutricional: as proteínas são fundamentais para todos os aspectos da cicatrização. Desde a síntese de colágeno, proliferação epidérmica, neovascularização, etc. A vitamina $C$ é essencial para a hidroxilação da lisina e prolina no processo de síntese de colágeno. É também importante para a produção de fibroblastos e integridade capilar. A vitamina $A$, é essencial à formação e manutenção da integridade do tecido epitelial. As vitaminas do complexo B são necessárias para a efetiva ligação cruzada entre as fibras colágenas, para função linfocitária e produção de anticorpos. Os oligoelementos como o zinco, ferro, cobre e manganês, são necessários para a formação do colágeno. A água é o mais importante nutriente, uma vez que corresponde cerca de $55 \%$ do peso corporal e compõe todas as atividades celulares e funções fisiológicas (SANTOS, 2000; BORGES, 2001).

Condições Sistêmicas: uma das mais importantes é o diabetes mellitus, que se destaca pela redução na resposta inflamatória e gera maior risco de infecção. Além disso, a neuropatia reduz a percepção sensorial, aumentando o risco para desenvolvimento de lesões. A insuficiência renal interfere na manutenção da pressão arterial, equilíbrio hidroeletrolítico e processo de coagulação. Existem outras 
condições sistêmicas como doença reumatológica, hepática, neurológica, intestinal, hematológica, que por mecanismos diretos ou indiretos, influenciam negativamente no processo de reparação tissular ou predispõe o indivíduo a riscos maiores de desenvolvimento de lesões. Alguns tratamentos sistêmicos podem comprometer o processo de reparação tissular, tais como a radioterapia, quimioterapia, esteróides e drogas antiinflamatórias (SANTOS, 2000).

Infecção: Infecção bacteriana da ferida é a causa local mais comum de uma cicatrização prolongada (SILVER, 1984), porém, a simples presença de bactérias não caracteriza a infecção, que deve ser diferenciada da colonização (LODOVICI, 1994). Todas as feridas são contaminadas pós-operatoriamente pela flora bacteriana residente. Infecções clínicas ocorrem quando um número crítico de organismos patogênicos está presente. A bactéria lentifica a cicatrização pela ativação da via alternada do complemento prolongando a fase inflamatória da cicatrização de feridas (FEARSO; AUSTEN, 1977). A infecção é o maior inimigo da cura de uma ferida. Ao determinar maior destruição de tecidos e retardar o processo de reparação, aumenta a formação de tecido cicatricial, que poderá comprometer a função, a estética ou ambos (LODOVICI, 1994). Assim, as culturas devem estar indicadas não só quando há indícios clínicos de infecção local ou sistêmica, mas também em casos de comprometimento ósseo, e de feridas que não cicatrizam, apesar do tratamento adequado (SANTOS, 2000).

Fatores mecânicos: A pressão, fricção e cisalhamento são forças mecânicas que podem contribuir para romper a integridade tissular. Embora associadas às úlceras por pressão, podem estar relacionadas com as demais úlceras crônicas, especialmente as vasculogênicas ou neuropáticas (BRYANT, 1992; ABLA; ISHIZUKA, 1995).

Suturas muito apertadas ou com a borda de uma ferida fechada com uma tensão excessiva promovem uma isquemia tecidual e podem resultar na necrose das bordas da ferida, deiscência ou uma propensão para uma infecção secundária. Esses fatores também podem promover formação de uma cicatriz hipertrófica nas áreas de máxima tensão ou áreas de deiscências deixadas para cicatrizar por segunda intenção (BORGES; ALEXANDER, 1962). 
Um sangramento excessivo e a formação de um hematoma em um segmento suturado podem romper mecanicamente o fechamento e levar a deiscência da ferida. O sangue coagulado pode servir como um excelente meio de cultura podendo contribuir para o desenvolvimento de uma séria infecção bacteriana da ferida. A dissecção cuidadosa do tecido, a ligação apropriada dos vasos e a meticulosa eletrodissecação por ponto de sangramento de capilares minimiza a formação de hematomas (ANGEL et al., 1986).

Pouco óxido nítrico estimula a proliferação celular, e o aumento do número de fibroblastos pode levar a cicatrizes hipertróficas. O aumento de óxido nítrico resulta em um aumento de macrófagos ativados evidenciando um processo de ativação celular. O óxido nítrico induz também um fenótipo de deslocamento de queratinócitos, auxiliando no processo de fechamento da incisão (GODOY, 2002; WITTE e BARBUL, 2002). 


\section{MATERIAIS E MÉTODOS}

Foram utilizados ratos machos, da linhagem Wistar Hannover (Rattus norvegicus albinus), com aproximadamente 60 dias de idade e média de peso variando entre 200 - $300 \mathrm{~g}$, provenientes do Biotério do Instituto de Ciências Biomédicas (ICB III) da Universidade de São Paulo (USP).

Para o delineamento experimental, os animais foram distribuídos aleatoriamente nos seguintes grupos e estão ilustrados na figura 3.

Grupo I (GI): Controle negativo - animais normais - constituído por seis animais que serviram de parâmetro para avaliar as possíveis alterações ocorridas no tegumento dos demais grupos (GII e GIII) e foram avaliados em dois momentos distintos: quatro dias pós-LTE (três animais) e quatorze dias pós-LTE (três animais)

Grupo II (GII): Controle positivo - animais submetidos à LTE - constituído por seis animais que serviram de parâmetro para avaliar possíveis alterações ocorridas no tegumento no que tange à regeneração natural do tecido epitelial, avaliados em dois momentos distintos: quatro dias pós-LTE (três animais) e quatorze dias pós-LTE (três animais)

Grupo III (GIII): Tratados - animais submetidos à LTE e tratados com BML constituído por dez animais que tiveram parte da superfície da LTE recoberta pela BML e que foram avaliados nos períodos de quatro dias pós-LTE (cinco animais) e quatorze dias pós-LTE (cinco animais) 


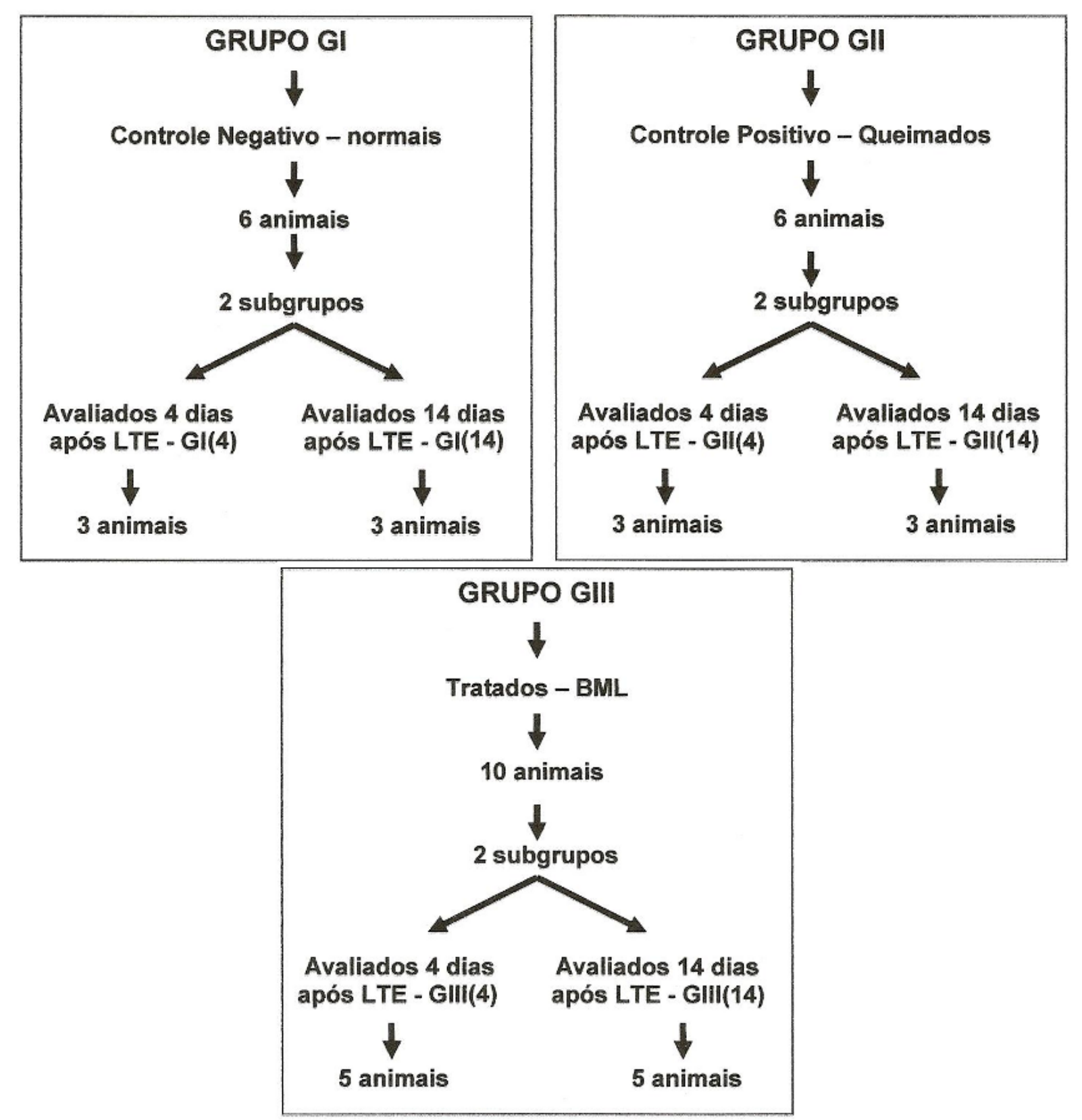

Figura 3 - Esquema da distribuição aleatória dos grupos 
Todos os animais foram mantidos individualmente, em gaiolas metabólicas ${ }^{3}$ ilustradas na figura 4, as quais permitem a higienização diária com álcool etílico e o não contato dos animais com suas fezes e urina, com o objetivo de eliminar possíveis infecções, inclusive os animais do grupo Gl foram mantidos nestas gaiolas a fim de que fossem submetidos à todo o estresse que os demais animais foram submetidos.
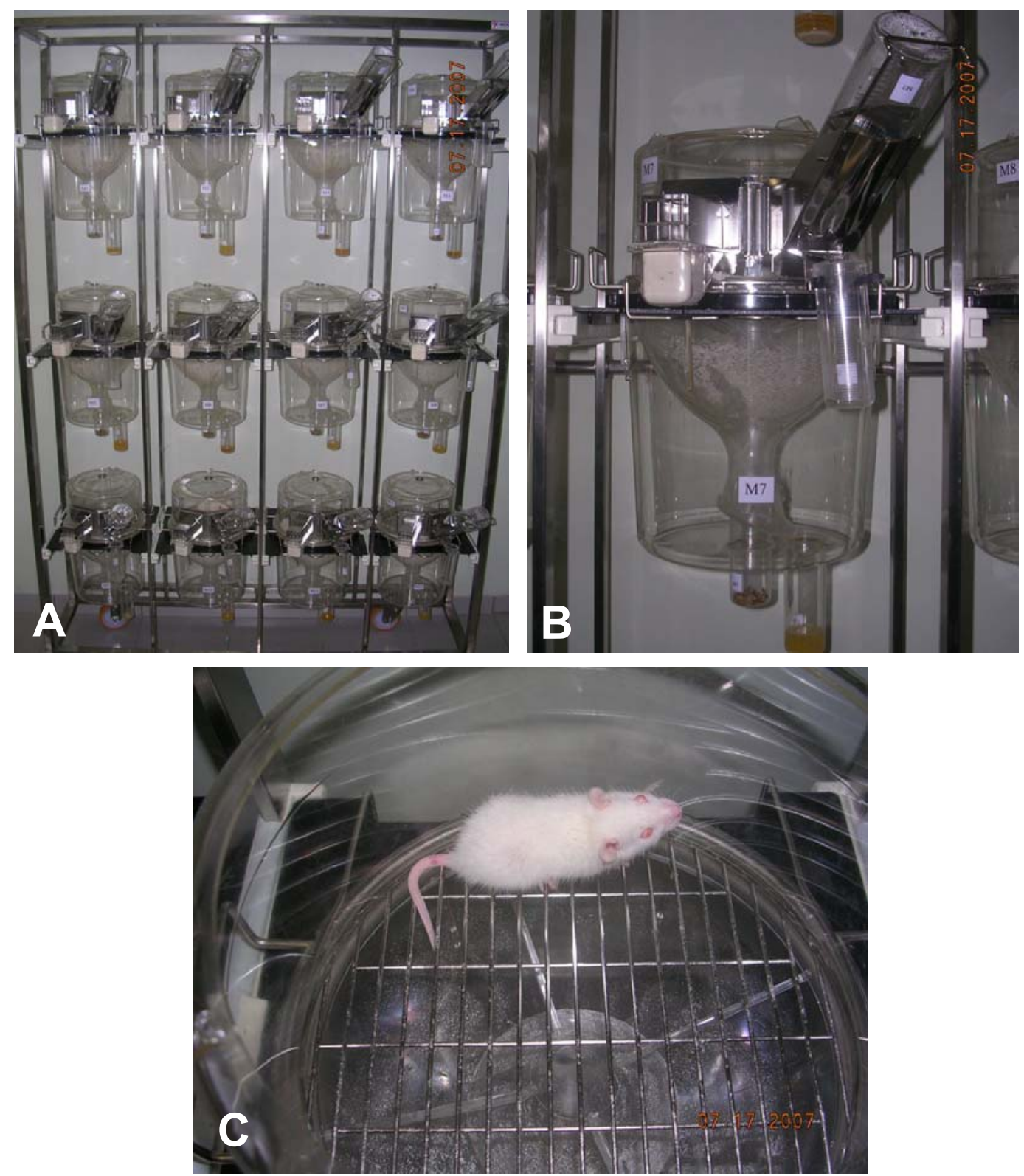

Figura 4 - Monitoramento dos animais: (A) Estante vertical com 12 gaiolas metabólicas, (B) Gaiola metabólica, (C) Compartimento em que foram alojados os animais

\footnotetext{
${ }^{3}$ TECNIPLAST®, modelo 3700M081, Buguggiate, Va, Itália - Biotério do departamento de Anatomia ICB/USP.
} 
Para que os animais se ajustassem às novas condições que são oferecidas pelas gaiolas metabólicas, os mesmos deixaram as caixas de polipropileno com maravalha de pinus e foram submetidos às estas novas condições cinco dias anteriormente ao início dos protocolos experimentais (Figura 5).

Todos os animais permaneceram em sala climatizada ${ }^{4}\left(21 \pm 2^{\circ} \mathrm{C}\right)$, com iluminação artificial, ciclos claro/escuro de 12/12 h e exaustão de ar e ventilação contínua. Estes receberam, durante todo o período, água filtrada e ração comercial para roedores ${ }^{5}$, ad libitum, em ambiente sanitariamente controlado.
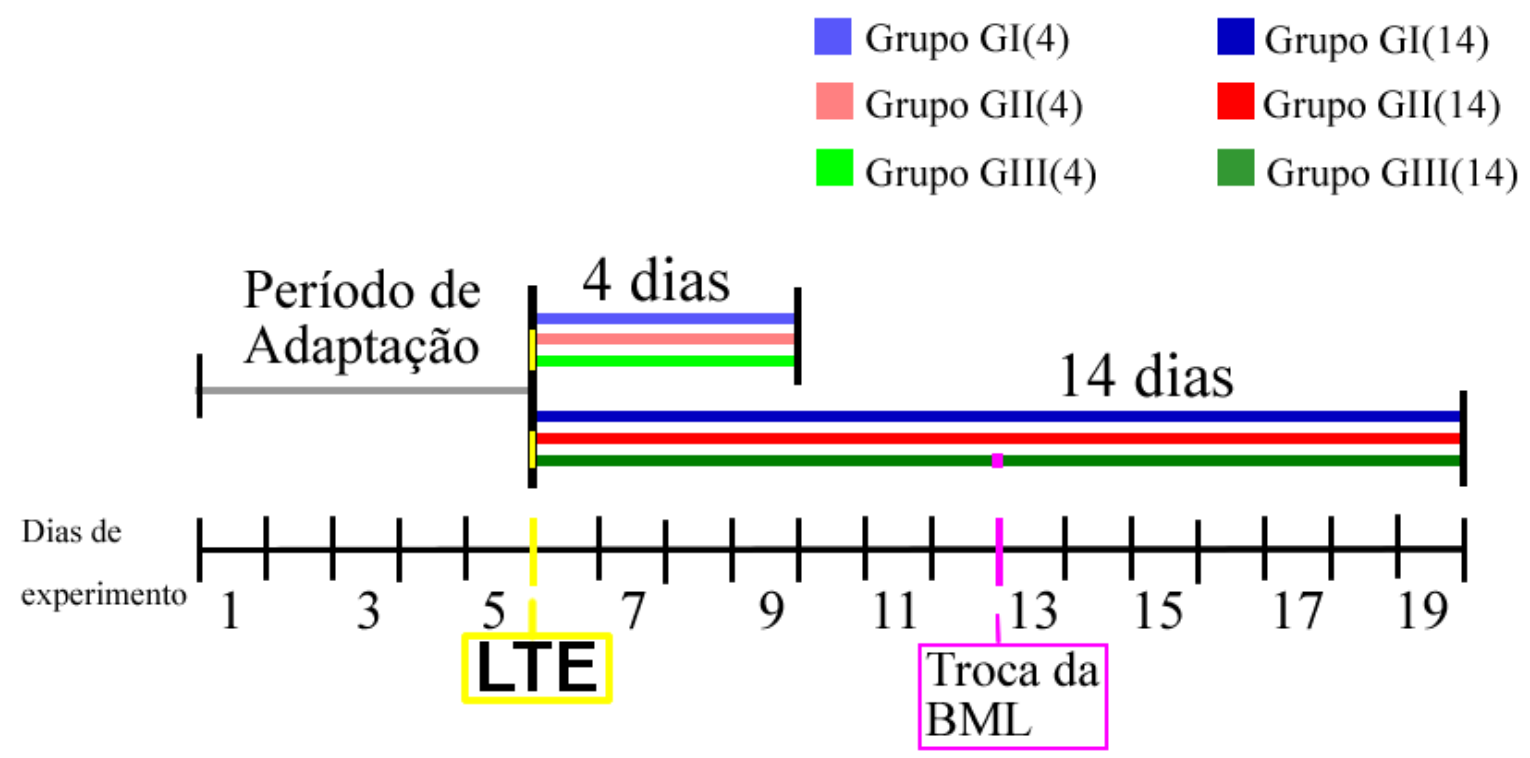

Figura 5 - Período experimental (em dias) pós-lesão térmica por escaldamento (LTE) dos grupos de animais GI, GII e GIII: O dia 5 corresponde ao dia da LTE para os animais dos grupos GII e GIII

\footnotetext{
${ }^{4}$ Biotério do Departamento de Anatomia - ICB/USP

${ }^{5}$ Nuvitab CR-1 da empresa Nuvital Nutrientes S/A
} 


\subsection{DELINEAMENTO PARA A LTE E APLICAÇÃO DA BML}

Para os animais dos grupos GIl e GIII, estes foram previamente anestesiados, por via intraperitoneal, com Cloridrato de Tiletamina e Cloridrato de Zolazepan ${ }^{6}$ em dose de $1 \mathrm{~mL} / \mathrm{Kg}$. A fim de evitar possíveis influências do anestésico nos resultados, os animais do grupo GI também foram anestesiados (IBEBUNJO e MARTYN, 2001).

Em seguida, após a verificação dos pesos iniciais de todos os animais, os mesmos foram mantidos em decúbito ventral. Foi realizada a tricotomia do dorso dos exemplares de todos os grupos, inclusive dos animais do grupo GI. Após a tricotomização desses animais, os mesmos tiveram a área higienizada com água destilada e auxílio de gaze (100\% algodão).

Feito isto, os animais dos grupos GIl e GIII, foram imersos em água a $87^{\circ} \mathrm{C}$ por um período fixado ${ }^{7}$, em que, o tempo de exposição à água quente foi aquele preconizado por Newman et al., (1982), ou seja, 10 segundos para o dorso. Este procedimento foi realizado em equipamento conhecido como Banho Maria ${ }^{8}$ onde a temperatura da água foi ajustada e monitorada.

A padronização da LTE foi calculada de acordo com a massa corporal dos animais $\left(18 \%\right.$ da área corporal $=10 . \mathrm{W}^{2 / 3}$, onde $\mathrm{W}=$ massa corporal correspondente a uma área retangular de, aproximadamente, $26 \mathrm{~cm}^{2}$ ) e foi realizada através de um dispositivo desenvolvido no Laboratório de Anatomia Funcional Aplicada à Clínica e à Cirurgia (LAFACC), do ICB/USP, conforme descrito por Walker e Mason, (1968).

Anteriormente à sutura da BML, principalmente os animais do grupo GIII tiveram as unhas aparadas, com o objetivo de se evitar que a BML fosse arrancada durante o período experimental. Para padronização dos procedimentos empregados, todos os animais dos demais grupos também tiveram as unhas aparadas.

Da amostra de BML foi retirada uma fatia compatível com a área da queimadura no dorso do animal, uma vez que a proporção desta biomembrana que temos disponível é de $8 \times 8 \mathrm{~cm}$, ilustrada na figura 6 . Posteriormente seguiu-se 0 processo de sutura da BML ao corpo dos animais do grupo GIII, com auxílio de uma

\footnotetext{
${ }^{6}$ Zoleti $^{\circledR} 50$, Virbac ${ }^{\circledR}$ Saúde Animal

${ }^{7}$ Procedimento realizado no Laboratório de Anatomia Funcional Aplicada à Clínica e a Cirurgia LAFACC/ICB/USP.

${ }^{8}$ Cientec
} 
agulha e linha (monofilamento de seda, $4-0^{9}$ ). A BML foi bem ajustada e suturada na pele do dorso dos animais recobrindo parte da área da ferida. Propositalmente foi deixada uma parte da ferida sem o tratamento com a BML, para uma comparação macroscópica do aspecto evolutivo da cicatrização nos animais.

A fim de padronizar os experimentos para todos os grupos, foram aplicadas suturas nos animais dos grupos GI e Gll; porém, nada foi colocado sobre o dorso dos mesmos e sim, apenas suturas com o monofilamento de seda 4-0 cuja posição correspondeu, aproximadamente àquelas utilizadas para fixação da BML no dorso dos animais do grupo GIII.

Nos animais do grupo GIII(14), procedeu-se a uma troca da BML no oitavo dia pós-LTE. Para isto, os animais foram anestesiados de acordo com o protocolo da presente pesquisa e tiveram a área da lesão higienizada com gaze (100\% algodão), embebido em água destilada.

Os procedimentos anteriormente descritos no item 4.2.1 estão ilustrados na figura 7.

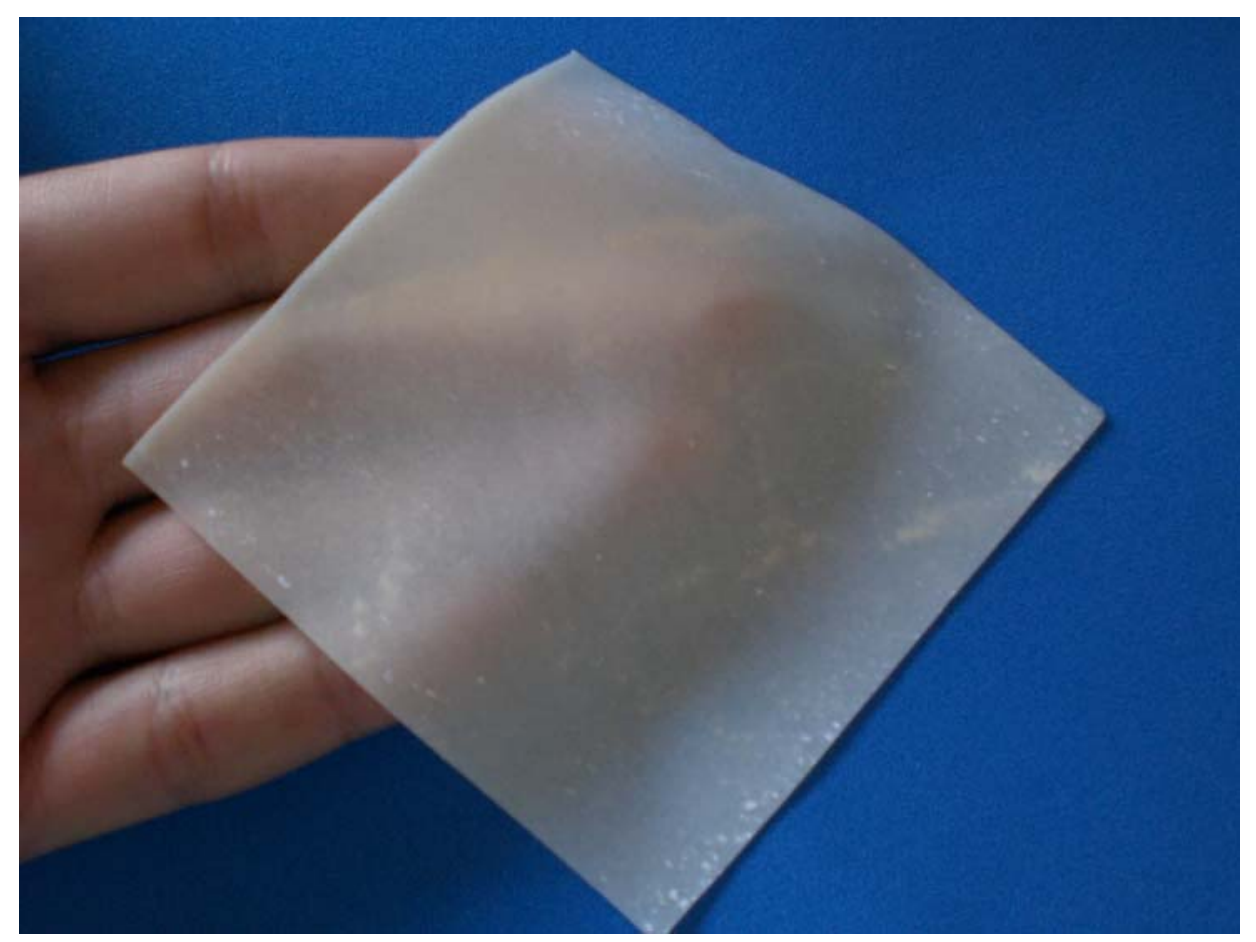

Figura 6 - Biomembrana de látex natural (BML): Produto confeccionado a partir do látex natural da árvore da borracha Hevea brasiliensis

\footnotetext{
${ }^{9}$ Technew
} 

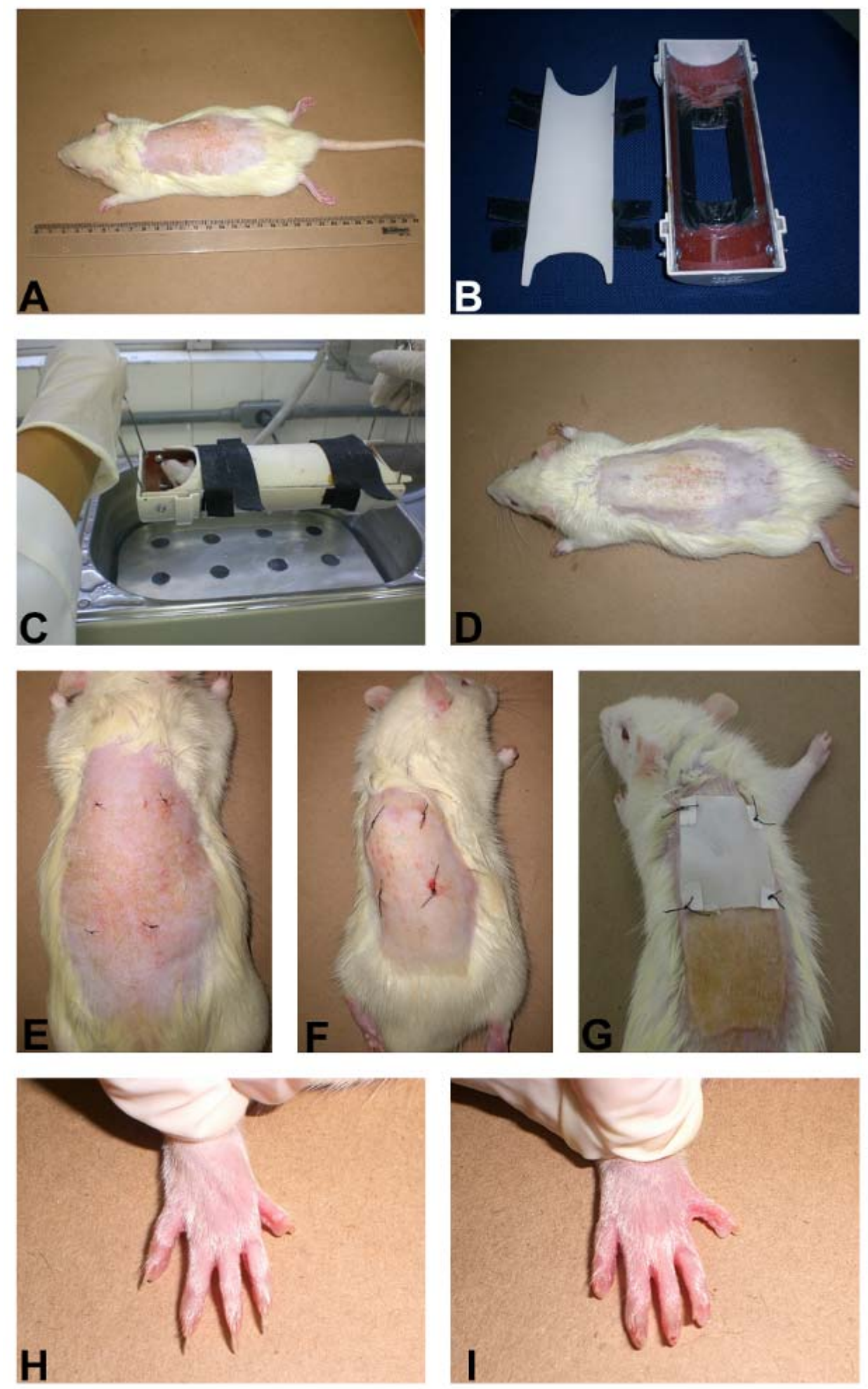

Figura 7 - Procedimento experimental: (A) Animal após a tricotomia do dorso e higienização da área a ser submetida à lesão. (B) Dispositivo utilizado para a realização da LTE, desenvolvido no Laboratório de Anatomia Funcional Aplicada à Clínica e à Cirurgia (LAFACC) do ICB/USP, conforme descrito por Walker e Mason (1968). (C) Animal sendo submetido à imersão em água quente. (D) Animal com o dorso queimado imediatamente após a LTE. (E, F e G) Animais dos grupos GI, GII e GIII com suturas. Observar padronização de suturas para todos os grupos. (H) Animal com as unhas intactas. (I) Animal com as unhas aparadas 


\subsection{PERÍODO PÓS-LTE}

Para a analgesia pós-lesão foi administrado por via subcutânea Morfina ${ }^{10}$ (2,0 mg/Kg) a cada 4-6 horas, durante 3 dias consecutivos, e associado a este opióide, foi administrado pela mesma via, o antiinflamatório e analgésico FlunixinMeglumine $^{11}(2,5 \mathrm{mg} / \mathrm{kg}) \quad$ em doses diárias durante 3 dias consecutivos (FLECKNELL, 1999).

\subsection{PROCEDIMENTO PARA ORTOEUTANÁSIA}

Não ocorreu morte entre os animais durante o período experimental e os animais de todos os grupos (GI, GIl e GIII) foram ortoeutanasiados dentro dos períodos preconizados, sendo submetidos à câmara de dióxido de carbono ${ }^{12}\left(\mathrm{CO}_{2}\right)$ imediatamente após a verificação do peso.

\subsection{AVALIAÇÃO DOS PESOS DOS ANIMAIS}

Para todos os animais de todos os grupos (GI, GIl e GIII), foi verificado o peso inicial no quinto dia experimental, e o peso final imediatamente antes da ortoeutanásia. Para a avaliação foi considerada a variação de peso $(\Delta)$ que é igual à diferença entre os pesos finais e pesos iniciais segundo a equação abaixo:

$$
\Delta=\text { (peso final }- \text { peso inicial })
$$

\footnotetext{
${ }^{10}$ Sugestão da Comissão de Bioética - FMVZ/USP

${ }^{11}$ Schering-Plough Animal Health

${ }^{12}$ Biotério do Departamento de Anatomia - ICB/USP.
} 


\subsection{AVALIAÇÃO MACROSCÓPICA (QUALITATIVAS)}

As avaliações macroscópicas foram realizadas baseadas nas observações clínicas ao natural, durante o período experimental, as quais foram documentadas com auxílio de câmara digital ${ }^{13}$ evidenciando todas as principais fases do experimento.

\subsection{DISSECAÇÃO, INDIVIDUALIZAÇÃO E PREPARAÇÃO DAS AMOSTRAS}

O tegumento dorsal de todos os animais foi retirado com auxílio de bisturi e pinça anatômica. Para os animais dos grupos Gll e GIII, as amostras constaram da ferida ou cicatriz no centro, circundada por, aproximadamente, $1 \mathrm{~cm}$ de tecido normal composto pelas quatro camadas do tegumento desses animais (epiderme, derme, hipoderme e camada muscular - panniculus carnosus) de acordo com Manzi et al., (2003).

As amostras foram embaladas em papel alumínio e mantidas em freezer ${ }^{14}$ $-80^{\circ} \mathrm{C}$ até a utilização para amostragem de acordo com os métodos estereológicos.

Em seguida, de acordo com a técnica empregada para a realização do "fractionator" (GUNDERSEN, 1986), em cada amostra retangular foi realizada uma secção no sentido do seu maior eixo, dividindo-a em duas metades. Cada uma dessas metades foi subdividida em 4 partes aproximadamente iguais, a partir de secções perpendiculares à primeira, perfazendo um total de oito fragmentos com, aproximadamente, 1,6 $\mathrm{cm}^{2}$ em média. Quatro destes fragmentos foram amostrados aleatoriamente, de acordo com a tabela de número randômicos (Anexo $A$ ), para procedimento histológico.

Após esta amostragem, estes quatro fragmentos selecionados foram cortados perperdiculares ao seu menor eixo gerando, novamente, oito amostras com, aproximadamente, $0,76 \mathrm{~cm}^{2}$ em média. Como a pele é uma estrutura anisotrópica (HOWARD; REED, 2005), para a realização dos cortes histológicos cada uma das

\footnotetext{
${ }^{13}$ Casio EX-Z75

14 Thermo Forma.
} 
Figura 8 - Técnica do Fractionator segundo Gundersen (1986): (A) Amostra retangular total. (B) amostra seccionada no sentido do seu maior eixo, dividindo-a em duas metades. (C) Cada uma dessas metades foi subdividida em 4 partes aproximadamente iguais, a partir de seccões perpendiculares à primeira, perfazendo um total de oito fragmentos. (D) Quatro destes fragmentos foram amostrados aleatoriamente, de acordo com a tabela de número randômicos, para procedimento histológico. (E) Fragmentos restantes que foram destinados à microscopia eletrônica de varredura. (F) Os quatro pedaços selecionados para microscopia de luz foram cortados perperdiculares ao seu maior eixo gerando oito pedaços. (G) Cada fragmento foi verticalizado. (H) Suporte de cortiça ulitizado para montagem dos fragmentos e, finalmente, o fragmento envolto por um meio de inclusão especial para congelamento de tecidos biológicos e colocado em nitrogênio líquido 
amostras foi verticalizada segundo Baddeley et al. (1986) e, foram montadas sob suporte de cortiça, envoltas por um meio de inclusão especial para congelamento de tecidos biológicos ${ }^{15}$ e congeladas em nitrogênio líquido (Figura 8). Finalmente, foram levadas à câmara do criostato $^{16}$ a $-25^{\circ} \mathrm{C}$, onde foram seccionadas em espessura de $10 \mu \mathrm{m}$, de modo que a face dermoepidérmica ficou voltada para a superfície de corte do bloco.

Os quatro fragmentos restantes dos oito primeiros (Figura $8(E)$ ) foram fixados em solução de Karnovsky modificada, para posterior utilização em protocolo de microscopia eletrônica de varredura (MEV).
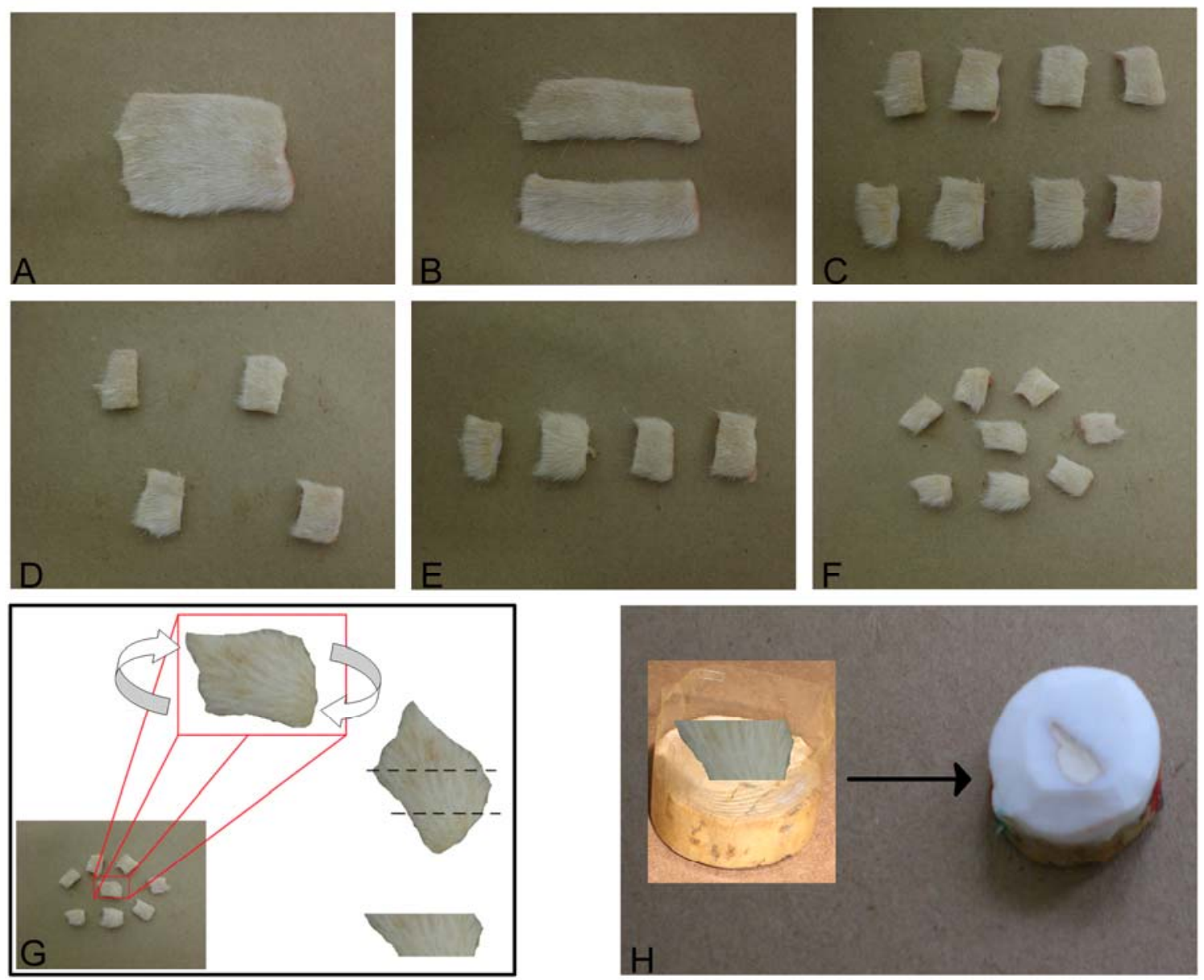

\footnotetext{
${ }^{15}$ AOTEC Instrumentos Científicos LTDA, São Paulo, SP, Brasil

${ }^{16}$ Leica Microsystems, modelo CM 1850, Wetzlar, Alemanha - LAFACC/ICB/USP.
} 


\subsection{MICROSCOPIA DE LUZ}

Foram realizadas secções seriadas de $10 \mu \mathrm{m}$ de espessura em criostato, mantido a uma temperatura de $-25^{\circ} \mathrm{C}$, as quais foram acomodadas em lâminas foscas e lapidadas para histologia e, armazenadas em caixas porta lâminas de microscopia com capacidade para 100 lâminas em freezer $-20^{\circ} \mathrm{C}$ até o momento em que foram submetidas aos diferentes métodos de coloração ${ }^{17}$.

Para avaliação dos aspectos gerais e das espessuras do tegumento dos animais e do tecido de granulação, as secções foram coradas com Hematoxilina$\operatorname{eosina}^{18}$ (H.E) (ROMEIS, 1968).

Para avaliação das fibras colágenas, as secções foram coradas pelo método de Picro-sirius $^{19}$ (JUNQUEIRA et al., 1979) as quais foram avaliadas sob luz polarizada $^{20}$ para tipificação das fibras colágenas e quantificação das mesmas presente no tecido de granulação.

Para as fibras elásticas maduras, as secções foram coradas pelo método de Verhoeff $^{21}$ (PROPHET et al., 1992).

A montagem dos cortes foi realizada entre lâmina e lamínula, com Entellan ${ }^{22}$.

Todos os preparados histológicos foram observados em microscópio ${ }^{23}$. As alterações histopatológicas foram documentadas em fotomicrografias. Estas fotomicrografias foram obtidas neste mesmo microscópio acoplado à câmara fotográfica $^{24}$.

Para tanto, foram adquiridas imagens que foram capturadas através do sistema de imagem computadorizada ${ }^{25}$.

\footnotetext{
${ }_{17}^{17}$ Procedimento realizado no LAFACC/ICB/USP.

${ }^{18}$ Método de coloração realizado no Laboratório de Histologia e Embriologia do Departamento de Anatomia dos Animais Domésticos e Silvestres - FMVZ/USP.

19 Método de coloração realizado no Laboratório Multiusuário de Histologia do Departamento de Anatomia - ICB/USP

${ }^{20}$ Carl Zeiss, modelo Axioshop 40, Göttingen, Alemanha. Laboratório de Anatomia Funcional aplicada à Clínica e Cirurgia - LAFACC - ICB/USP.

${ }^{21}$ Método de coloração realizado no Laboratório Multiusuário de Histologia do Departamento de Anatomia do ICB/USP.

${ }^{22}$ Merck, Darmstadt, Alemanha

${ }^{23}$ Carl Zeiss, modelo Axioskop 40, Göttingen, Alemanha - LAFACC

${ }^{24}$ Carl Zeiss, modelo AxioCam HRC, Göttingen, Alemanha - LAFACC

${ }^{25}$ Carl Zeiss Microimaging, modelo Axioshop 40 e câmera Axiocam ligados ao software Axiovision Rel. 4.6, Göttingen, Alemanha - LAFACC - ICB/USP.
} 


\subsection{MICROSCOPIA ELETRÔNICA DE VARREDURA}

Para as análises em microscopia eletrônica de varredura, foram selecionadas aleatoriamente, com base na tabela de números randômicos (Anexo $A$ ), duas das quatro amostras totais, de aproximadamente $1,6 \mathrm{~cm}^{2}$ em média, de cada animal pertencentes aos grupos (GI, GII e GIII)

Essas amostras foram fixadas por imersão em solução de Karnovsky modificada ${ }^{26}$ por um período mínimo de 48 horas a $4^{\circ} \mathrm{C}$. Posteriormente, foram lavadas em água destilada ( $3 \times 5$ minutos) e, em seguida, desidratadas em série crescente de etanol (de $70 \%$ ao absoluto) por 15 minutos cada. A pós-fixação foi realizada com imersão das mesmas em uma solução aquosa de tetróxido de ósmio a $1 \%$, por 2 horas em geladeira.

Em seguida, o material foi seco em aparelho de ponto crítico $^{27}$ e montado e bases metálicas apropriadas. Após serem metalizadas com ouro $^{28}$, as amostras foram fotografadas em microscópio eletrônico de varredura ${ }^{29}$ e, posteriormente analisadas.

\subsection{ANÁLISE HISTOMORFOMÉTRICA (QUANTITATIVA)}

Foram realizadas medidas para avaliação das espessuras da derme, do tecido de granulação e da espessura total das camadas do tegumento dos animais de todos os grupos (GI, GII, GIII). Assim, utilizou-se o sistema de imagem computadorizada $^{30}$ com objetiva de $5 \mathrm{X}$ de aumento. Foram realizadas aleatoriamente cinco medidas em cinco secções diferentes, escolhidas com base na tabela de número randômicos (Anexo A) dentre as 8 secções totais obtidas de cada

\footnotetext{
${ }^{26} 2 \%$ de paraformaldeído, $25 \%$ de glutaraldeído e tampão fosfato, $\mathrm{pH} 7,3 ; 2 \mathrm{M}$.

${ }^{27}$ BAL-TEC, modelo CPD-030, Schalksmühle, Alemanha. Departamento de Anatomia - ICB/USP.

${ }^{28}$ BALZERS, modelo SCD-040, Reinraumtechnik Lanz, Alemanha. Departamento de Anatomia ICB/USP.

${ }^{29}$ LEO, modelo 435 VP, Departamento de Anatomia dos Animais Domésticos e Silvestres FMVZ/USP.

${ }^{30}$ Carl Zeiss Microimaging, modelo Axioshop 40 e câmera Axiocam ligados ao software Axiovision Rel. 4.6, Göttingen, Alemanha - LAFACC - ICB/USP.
} 
animal. Todos os parâmetros histomorfométricos foram medidos e apresentados em micrômetros $(\mu \mathrm{m})$.

O estudo da espessura total engloba todo o processo inflamatório da área lesada até a aponeurose profunda da musculatura esquelética dorsal (panniculus carnosus) de todos os animais. Procedimento ilustrado na figura 9.

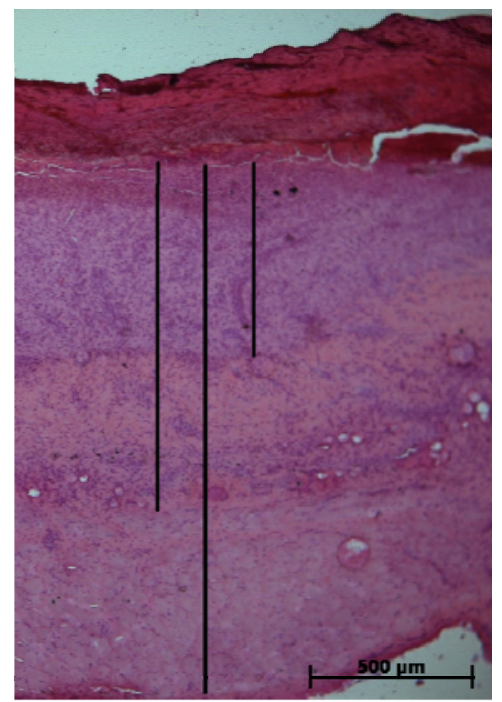

Figura 9 - Procedimento histomorfométrico para avaliação da espessura do tecido de granulação (linha menor), da derme (linha média) e da espessura total do tegumento (linha maior)

\subsection{AVALIAÇÃO ESTEREOLÓGICA (QUANTITATIVA)}

Foi aplicado o método estereológico para avaliação da Densidade de volume $\left(\mathrm{V}_{\mathrm{v}}\right)$ do sistema elástico e do colágeno presente no tecido de granulação. Para tanto, evitou-se fazer muitas avaliações nas porções da lesão, ou seja, na epiderme e no terço superficial da derme, onde as alterações são muito mais expressivas e com grande variabilidade entre um grupo e outro, o que dificultaria os aspectos comparativos.

A Densidade de volume $\left(V_{v}\right.$ ) expressa a fração do volume ocupado pela estrutura de interesse em relação ao volume total (volume referência). Para a estimação do $V_{v}$, foram utilizados um sistema teste composto por pontos eqüidistantes $(1,5 \mathrm{~cm}$ ) em forma de cruz (Anexo $B$ ), delimitados por um outro sistema teste formado por linhas de inclusão e exclusão, cuja área é de $105 \mathrm{~cm}^{2}$ 
(Anexo C). De modos sistemáticos e uniformemente alocados, esses sistemas testes foram sobrepostos, simultaneamente, sobre as fotomicrografias das secções de referência utilizadas. O número total de pontos sobre o espaço referência foi obtido; e de igual forma, o número total de pontos, sobre as estruturas de interesse foi registrado e, sendo assim, a seguinte equação foi utilizada (THOMPSON, 1930; DELESSE, 1847; ROSIWAL, 1898).

$$
\mathbf{V}_{\mathbf{V}}=\sum \mathbf{P}_{\text {(estrutura de interesse) }} / \sum \mathbf{P}_{\text {(espaço referência) }}
$$

Onde:

$\mathrm{P}_{\text {(estrutura de interesse) }}=$ número total de pontos que tocam a estrutura de interesse

$\mathrm{P}_{\text {(espaço referência) }}=$ número total de pontos que tocam o espaço referência

Esta estimativa do $V_{v}$ varia de 0 a 1 e geralmente é expressa em porcentagem (HOWARD; REED, 2005), multiplicando-se por 100.

A escolha pelo sistema teste, composto por pontos eqüidistantes em forma de cruz, em relação aos outros sistemas testes de pontos existentes, foi devido a uma abordagem mais precisa em relação à quantificação conferida a este sistema teste. Um dos quatro ângulos foi escolhido de forma aleatória com base na tabela de números randômicos e, então, somente foram contadas as estruturas que tocaram o centro destes pontos e/ou as estruturas que passaram pelo ângulo selecionado, os demais não foram considerados (HOWARD; REED, 2005).

Para a quantificação estereológica foram processadas oito amostras de cada animal, correspondentes a todos os grupos (GI, GII e GIII), de modo que, as secções obtidas em cada amostra eram distribuídas seriadamente nas diferentes lâminas destinadas aos diferentes métodos de coloração (H.E, Verhoeff e Picro-sirius), totalizando 66 lâminas, contendo 8 secções cada lâmina.

Para a quantificação das fibras elásticas e do colágeno presente no tecido de granulação, utilizou-se o sistema de imagem computadorizada ${ }^{31}$ com objetiva de 40X de aumento. Foram avaliados aleatoriamente, no mínimo cinco campos, dentre os 24 campos adquiridos em cada uma das oito secções, selecionados com base na tabela de número randômicos, até a soma de, no mínimo 100 pontos, de acordo com o método levemente modificado por Gundersen e Jensen (1987). Então, o número

${ }^{31}$ Carl Zeiss Microimaging, modelo Axioshop 40 e câmera Axiocam ligados ao software Axiovision Rel. 4.6, Göttingen, Alemanha - LAFACC - ICB/USP. 
de pontos que tocavam as fibras elásticas ou as fibras colágenas foram contados e, divididos pelo número de pontos que tocavam o espaço referência, ou seja, todos os pontos que tocavam a área do sistema teste empregado, considerando as limitações acerca das linhas de inclusão e exclusão, procedimento ilustrado na figura 10.

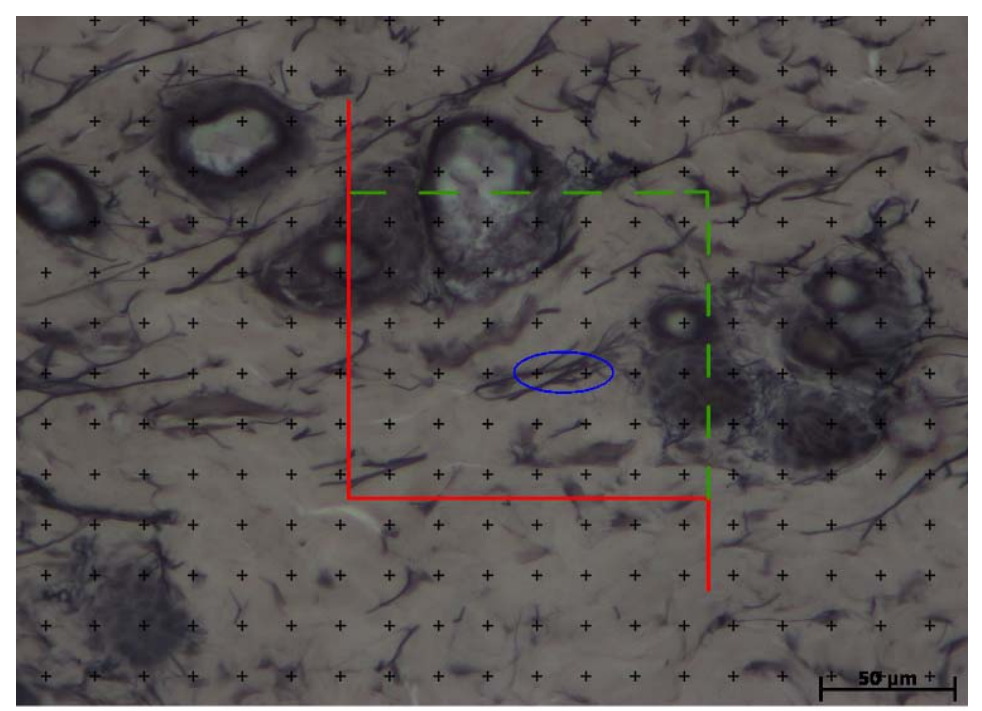

Figura 10 - Procedimento estereológico da contagem de pontos para avaliação da Densidade de volume $\left(\mathrm{V}_{\mathrm{v}}\right)$ das fibras elásticas

\subsection{ANÁLISE ESTATÍSTICA}

A análise estatística foi feita com o auxílio do Software estatístico Minitab ${ }^{32}$ e levado em consideração os princípios de amostragem sistemática e uniformemente aleatória (GUNDERSEN et al., 1999) onde para as variáveis que apresetaram distribuição simétrica e com igualdade de variância (homocedasticidade), utilizou-se o teste one way ANOVA seguido por comparações múltiplas pelo método de Tukey.

O teste $t$-Student foi usado para determinar estatisticamente a significância entre os GII(14) e GIII(14) relacionados ao tecido de granulação.

O nível de significância adotado para todos os testes foi de 5\% (ZAR, 1984), ou seja, valores foram considerados como significativos quando a probabilidade e índice de significância $(p)$ fossem menores que 0,05 $(p<0,05)$.

\footnotetext{
${ }^{32}$ Minitab®, v. 15, 2007.
} 


\section{RESULTADOS}

Durante todas as fases dos procedimentos experimentais, os animais foram assistidos clinicamente, não sendo registrado nenhum óbito nos períodos estudados.

\subsection{ANÁLISE QUALITATIVA}

Foram avaliados qualitativamente os aspectos macroscópicos e evolutivos da LTE, os aspectos microscópicos e os aspectos ultraestruturais

\subsubsection{Aspectos macroscópicos evolutivos da área queimada}

Imediatamente após LTE, a área do tegumento correspondente apresentouse elevada e esbranquiçada, circundada por uma zona hiperêmica.

Do primeiro ao quarto dia, verificou-se um aumento progressivo de flictenas com eliminação de uma secreção levemente viscosa que persistiu até, aproximadamente, o quarto dia. Devido ao contato com o ar, ocorreu o ressecamento dessa secreção, o que proporcionou o aparecimento de uma crosta delgada, que foi se espessando até por volta do $10^{\circ}$ dia pós-LTE. Esta crosta já era bem destacada à época do sacrifício, ou seja, no $14^{\circ}$ dia pós-lesão.

No oitavo dia, período em que se procedeu à troca da BML evidenciou-se uma área amarelo-esbranquiçada, bastante úmida, com certa maleabilidade e sem formação de crosta, de onde emanava um odor desagradável. Ainda, a partir do oitavo dia, verificou-se um espessamento do tegumento que se manteve até o décimo quarto dia, o último dia estipulado para o experimento. Durante todo o período experimental, pelo menos na inspeção à vista desarmada, não foi verificado o aparecimento de pêlos novos bem como não se evidenciou áreas com processo inflamatório agudo (Figura 11) 

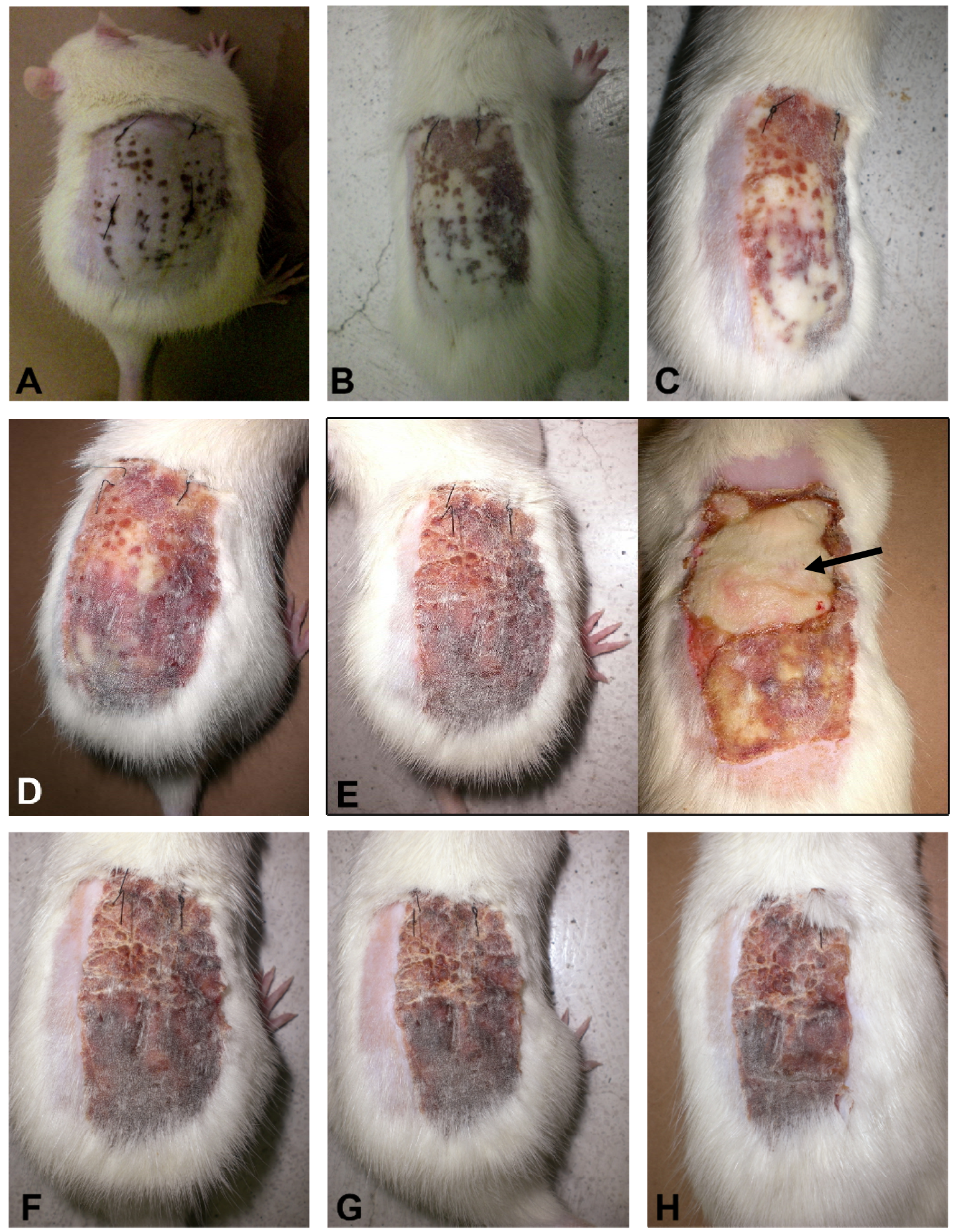

Figura 11 - Períodos evolutivos da LTE. No primeiro dia (A), segundo dia (B), terceiro dia (C) e quarto dia (D): No oitavo dia (E), verifica-se nos animais do grupo GIII (direita), uma área amarelo-esbranquiçada úmida (seta). As figuras F-H representam, respectivamente, 0 aspecto evolutivo da reparação da lesão no décimo, décimo segundo e décimo quarto dias pós-LTE 
Especificamente aos grupos estudados nos períodos de 4 e 14 dias, ao comparar a superfície externa do tegumento verificou-se, nos animais do grupo GII(4), a formação de uma crosta escura e delgada. Naqueles tratados com a BML, GIII(4), notou-se uma superfície amarelada e umedecida, caracterizando uma camada maleável. Ao analisar os animais do grupo GII(14), notou-se uma crosta espessa e avermelhada, com tendência ao desprendimento; já nos amimais do grupo GIII(14), foi evidente uma superfície amarelada, intumescida e úmida previamente descrita, bem diferente daquela existente nos animais GII(14) (Figura 12).
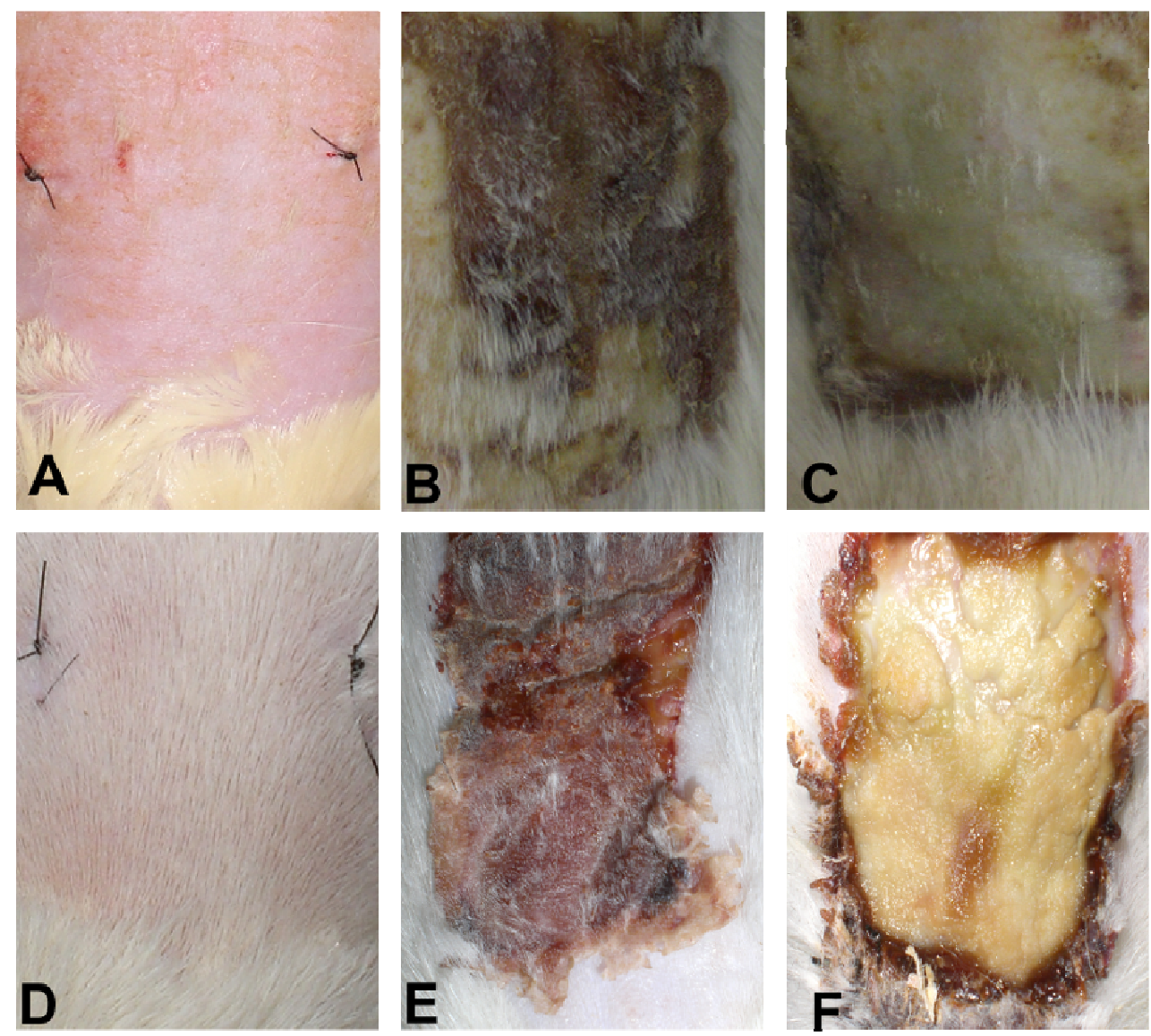

Figura 12 - Superfície externa do tegumento dos animais do grupo GI (A, D), dos animais do grupo GII (B, E) e dos animais do grupo GIII (C, F): Notar em (B), a crosta ressecada nos animais do grupo Gll(4), diferente da superfície amarelo-esbranquiçada e umedecida presente nos animais do grupo GIII(4), tratados com a BML (C). Com 14 dias pós-LTE, tanto a crosta em GII(14) como a camada amarelo-esbranquiçada e umedecida em GIII(14), tendem ao desprendimento 
Ao analisar a face profunda da pele, notou-se uma acentuação na coloração rosada dessa região nos animais do grupo Gll(4), submetidos à LTE e nos animais do grupo GIII(4) tratados com a BML. Nos grupos de 14 dias, verificou-se em GII uma tonalidade mais intensa, comparativamente ao mesmo grupo de 4 dias e uma coloração intensamente avermelhada nos animais do grupo GIII(14), sugestivo de uma intensa irrigação (Figura 13).
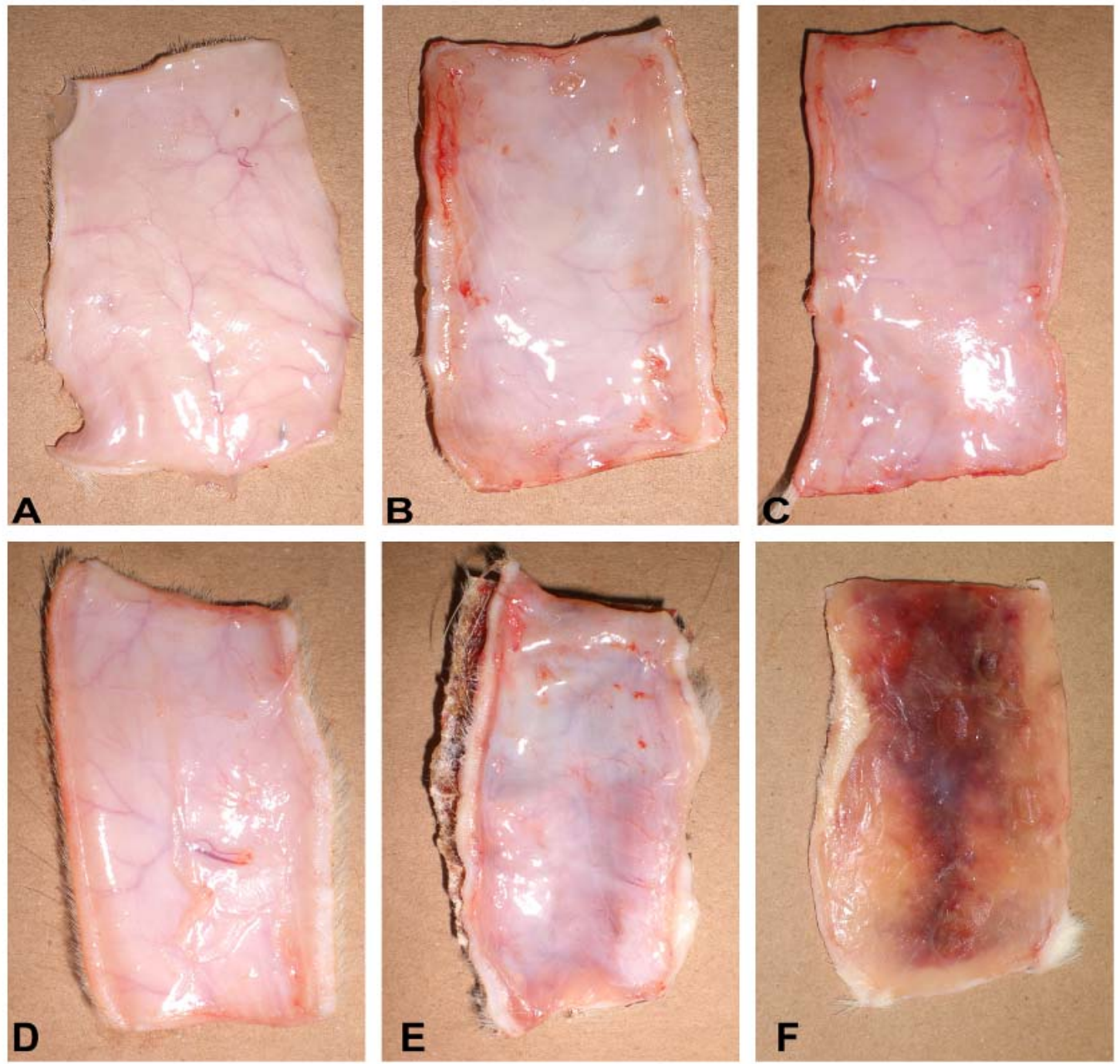

Figura 13 - Superfície profunda do tegumento dos animais do grupo GI (A, D), dos animais do grupo GII (B, E) e dos animais do grupo GIII (C, F): Notar o aspecto róseo intenso nos animais dos grupos $\mathrm{GII}(4)$, GII(14) e GIII(4) (respectivamente $\mathbf{B}, \mathbf{E}$ e $\mathbf{C}$ ). Em $\mathbf{F}$, a coloração intensamente avermelhada dessa região, nos animais GIII(14), tratados com a BML 


\subsubsection{Aspectos microscópicos}

O tempo de 10 segundos para a imersão em água a $85^{\circ} \mathrm{C}$ promoveu alterações graves no tegumento, caracterizando uma queimadura de segundo grau. Como aspecto geral, observou-se que a LTE comprometeu diretamente toda a epiderme, a derme papilar e partes superficiais da derme reticular.

A epiderme normal, tanto em $\mathbf{G I}(4)$ como em $\mathbf{G I}(14)$ apresentou-se composta de quatro camadas. Assim, a camada córnea queratinizada exibiu uma considerável espessura, quando comparada à camada granulosa, delgada e constituída por, no máximo dois estratos celulares. Subjacente, evidenciou-se a camada espinhosa composta por aproximadamente quatro estratos de células pavimentosas e a camada basal com apenas um estrato celular. A membrana basal é delicada e limita inferiormente a epiderme e superiormente a derme.

No tegumento dos animais dos grupos GII, não foi possível uma boa caracterização da epiderme, pois na maioria das secções a mesma encontrou-se deslocada da derme. Em outras secções esta camada exibiu um aspecto completamente destruído pela ação da LTE, inclusive com uma aparência necrótica. Nos animais do grupo GIII mesmo lesada, a epiderme ainda exibia certa preservação com relação à sua estratificação (Figura 14). 
Figura 14 - Fotomicrografias da epiderme dos animais dos grupos GI (A, B e C), GII(4) (D), GII(14) (E) GIII(4) (F), GIII(14) (G): Notar os extratos preservados em GI (camada córnea - seta maior; camada granulosa - seta menor, camada espinhosa - *; camada basal - cabeça de seta). Nos animais GIl verifica-se uma destruição dessa camada, não sendo possível destacar os seus folhetos. Nos animais tratados com a BML (GIII) observa-se uma certa preservação dessa camada, porém sem evidenciação nítida de seus folhetos. Técnica de coloração: HE 

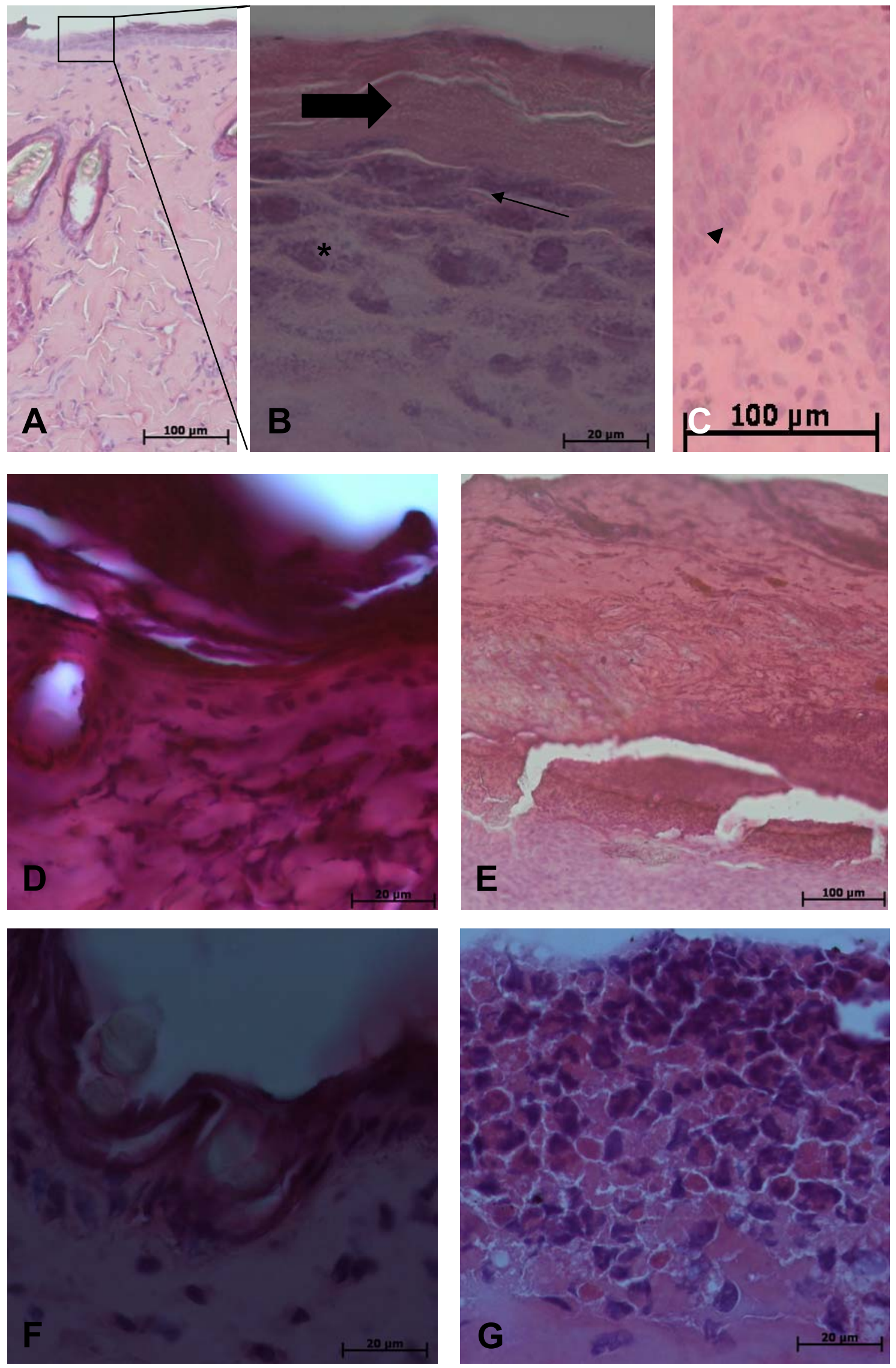
Nos animais do grupo GI, na região da derme não foi observada uma divisão clara entre a derme papilar e a derme reticular através dos métodos histológicos empregados neste estudo. Como característica dessa região, notou-se a presença de folículos pilosos e glândulas sebáceas com citoplasma claro e vacuolizado, porém consideravelmente volumoso. Ainda observou-se nesta região a presença de espaços (fendas) entre as fibras do tecido conjuntivo denso não modelado (Figura 15 - A). As fibras elásticas foram detectadas em grande quantidade na região subepidérmica, orientadas em diferentes direções. No terço profundo da derme, as fibras elásticas eram em menor quantidade e dispersas pelo tecido colágeno espesso dessa região. No entorno do bulbo dos folículos pilosos, e entre estes, verdadeira rede dessas fibras foram detectadas, orientadas em várias direções (Figura 16 - A, D e E).

Nos animais do grupo GII(4) observou-se o terço superficial da derme, gravemente afetado pela LTE, alterando tanto a estrutura dos folículos pilosos como o aspecto celular das glândulas sebáceas (Figura 15 - B). As fibras elásticas adensaram-se no terço médio da derme, a ponto de poder considerar a formação de uma verdadeira camada constituída por essas fibras. Os espaços anteriormente observados entre as fibras do tecido conjuntivo denso não modelado, nos animais do grupo GI, encontram-se preenchidos por uma aparente fusão das fibras colágenas, sugerindo desnaturação protéica devido à LTE. Nessa fase, ainda não se detectou a presença de tecido de granulação (Figura 16 - B e F).

Nos animais do grupo GII(14) foi facilmente identificado na região do terço médio da derme, um tecido relativamente espesso, de aspecto granuloso, totalmente celular, desprovido de fibras elásticas e/ou colágenas e não se detectou folículos pilosos ou glândulas sebáceas (Figura 15 - C) Nos métodos de coloração utilizados neste estudo, como o H.E e Verhoeff, este tecido aparece com uma coloração mais clara que no restante da derme. As fibras elásticas mostraram-se mais espessas, porém mais esparsas, não conferindo o aspecto nítido de uma "camada elástica", encontrado em GII(4) (Figura 16 - G)

Ao se avaliar os animais do grupo GIII(4) observou-se uma preservação do terço superficial da derme em geral, com formação de pequena quantidade de tecido de granulação (Figura 15 - D). Relativamente ao sistema elástico, verificou-se que esse tecido tinha um aspecto mais celular, com fibras entremeadas ao tecido 
Figura 15 - Fotomicrografias da derme dos animais dos grupos GI (A), GII(4) (B), GII(14) (C) GIII(4) (D), GIII(14) (E): Notar os folículos pilosos e glândulas sebáceas de aspecto normal nos animais do grupo GI (setas). Nos animais dos grupos de 4 dias (GII e GIII) verifica-se glândulas sebáceas e folículos pilosos alterados (setas) bem como tecido conjuntivo desorganizado (*). Com 14 dias (GII e GIII) evidencia-se o tecido de granulação (cabeça de seta). Nos animais tratados (GIIII) nota-se, em geral, uma tendência à reorganização da derme, bem como a presença de colágeno no tecido de granulação (seta). Técnica de coloração: HE 
colágeno e dispersas entre si. Essa distribuição assemelhou-se ao encontrado nos animais do grupo $\mathrm{Gl}$ (Figura $16-\mathrm{C}$ e $\mathrm{H}$ ).

Nos animais do grupo GIII(14) foi nítida a "invasão" do tecido colágeno no tecido de granulação e, eventualmente, presença de glândulas sebáceas e folículos pilosos. Nessa fase, ocorreu uma tendência à organização da região subepidérmica. Relativamente às fibras elásticas, sua densidade foi maior do que aquela encontrada nos animais GIII(4), sugestivo de intensa proliferação desse tecido nessa fase (Figura 15 - E e Figura 16 - I).
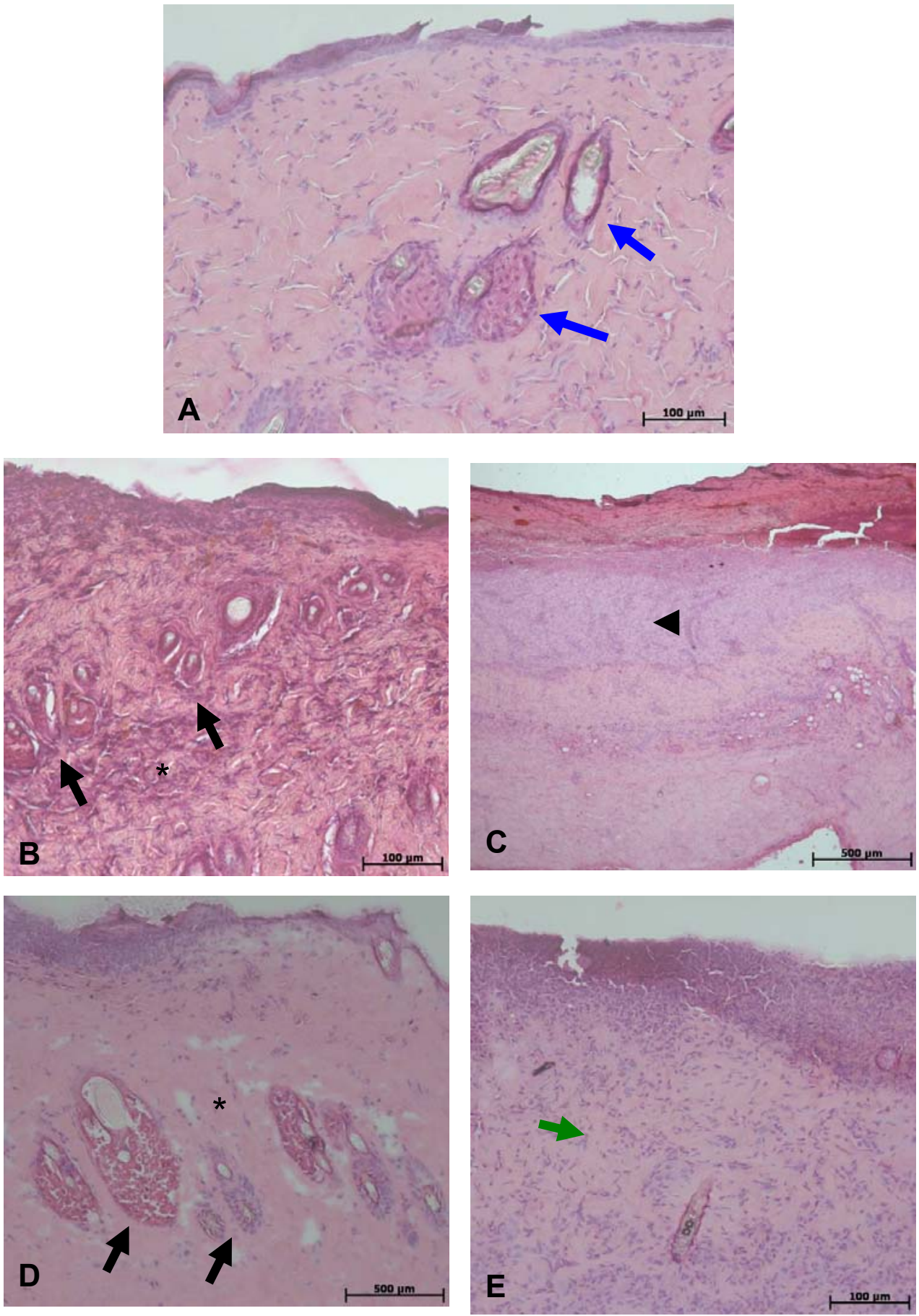
Figura 16 - Fotomicrografias da derme dos animais dos grupos GI (A, D e E), GII(4) (B, F), GII(14) (G), GIII(4) (C, H), GIII(14) (I): Nos animais do grupo $\mathrm{Gl}$, as fibras elásticas formam uma rede no terço superficial da derme e estão dispersas entre o tecido colágeno do terço profundo da derme. Nos animais do grupo GII(4), é nítido o adensamento das fibras elásticas no terço médio da derme. Notar, nos animais tratados com a BML (GIII), a proliferação do tecido elástico em meio ao tecido conjuntivo, principalmente no terço profundo da derme. Técnica de coloração: Verhoeff 

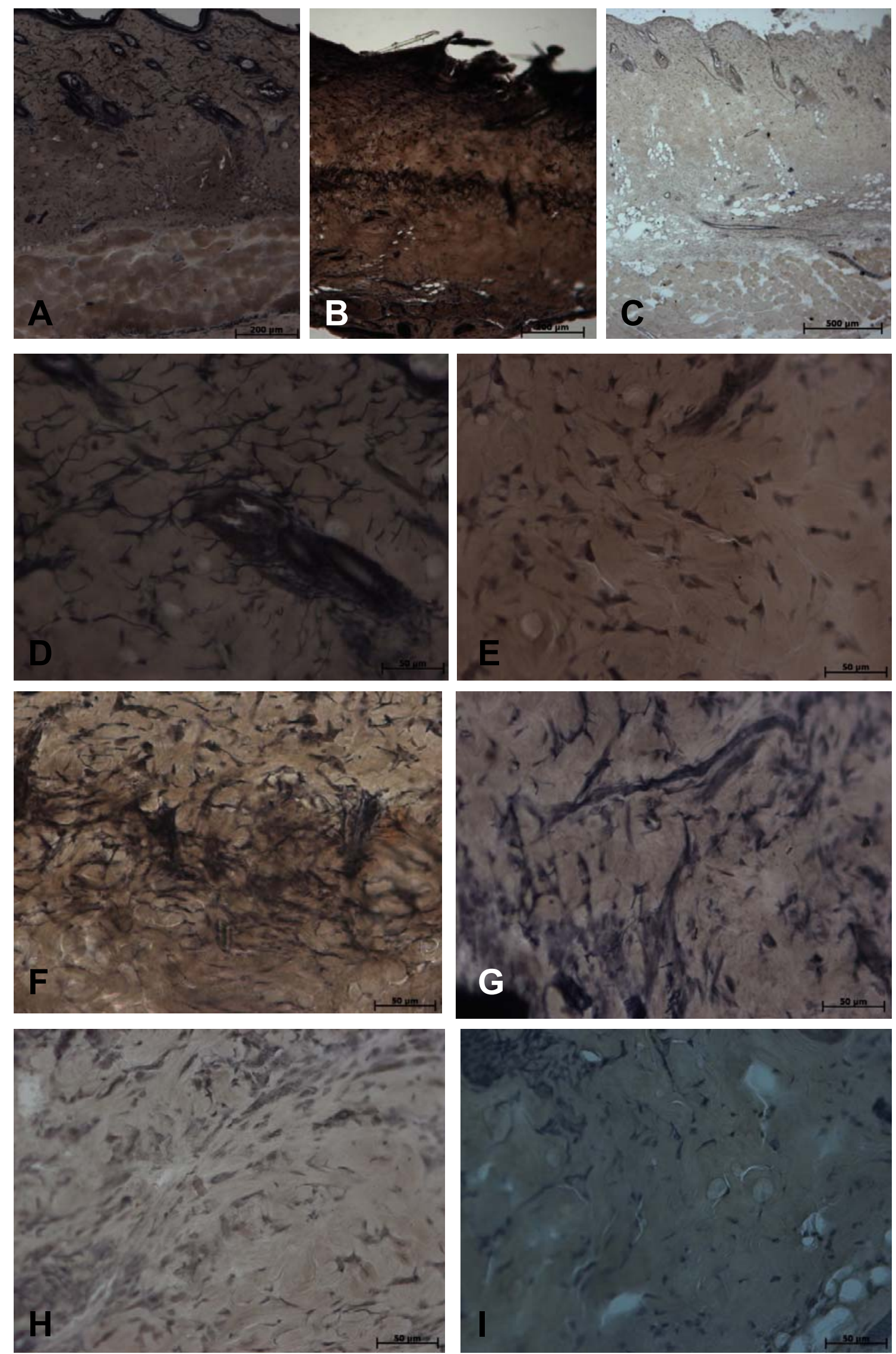
A análise do tecido colágeno através da luz polarizada permitiu verificar que, tanto no terço superficial quanto no terço profundo da derme dos animais do grupo GI, há um equilíbrio entre a distribuição das fibras colágenas dos tipos I (amarela, laranja ou vermelha) e III (verde). Nos animais do grupo GII(4) e GII(14), notou-se um aumento considerável das fibras colágenas do tipo I, principalmente no terço superficial da derme. Nos animais do grupo GIII, ocorreu um predomínio das fibras do tipo I nos animais do grupo GIII(4) e, muito embora tenha sido detectada uma proliferação das fibras do tipo III nos animais do grupo GIII(14), o aspecto nessa fase ainda não se assemelhava àquele verificado nos animais do grupo Gl (Figura 17).

Não foi possível detectar com precisão essas fibras no tecido de granulação dos animais do grupo GII(14); porém, elas constituíram uma malha evidente nesse mesmo tecido nos animais do grupo GIII(14), formada principalmente por fibras do tipo III (Figura 18). 
Figura 17 - Fotomicrografias da derme dos animais dos grupos GI (A, B; C e D), GII (E, F), GIII (G, H): Notar, em A e B, a coloração de Picrosirius sem e com luz polarizada respectivamente. Nos animais do grupo GI, nota-se um equilíbrio entre as fibras colágenas dos tipos I e III, sendo (C), o terço superficial da derme e (D), o terço profundo. Nos animais do grupo GII, há um predomínio das fibras colágenas do tipo I, principalmente no terço superficial da derme $(E)$, sendo $(\mathrm{F})$ o terço profundo. Os animais tratados com a BML (GIII) exibem um ligeiro predomínio das fibras colágenas do tipo I tanto no terço superficial $(G)$ quanto no terço profundo da derme $(H)$. Técnica de coloração: Picro-sirius 

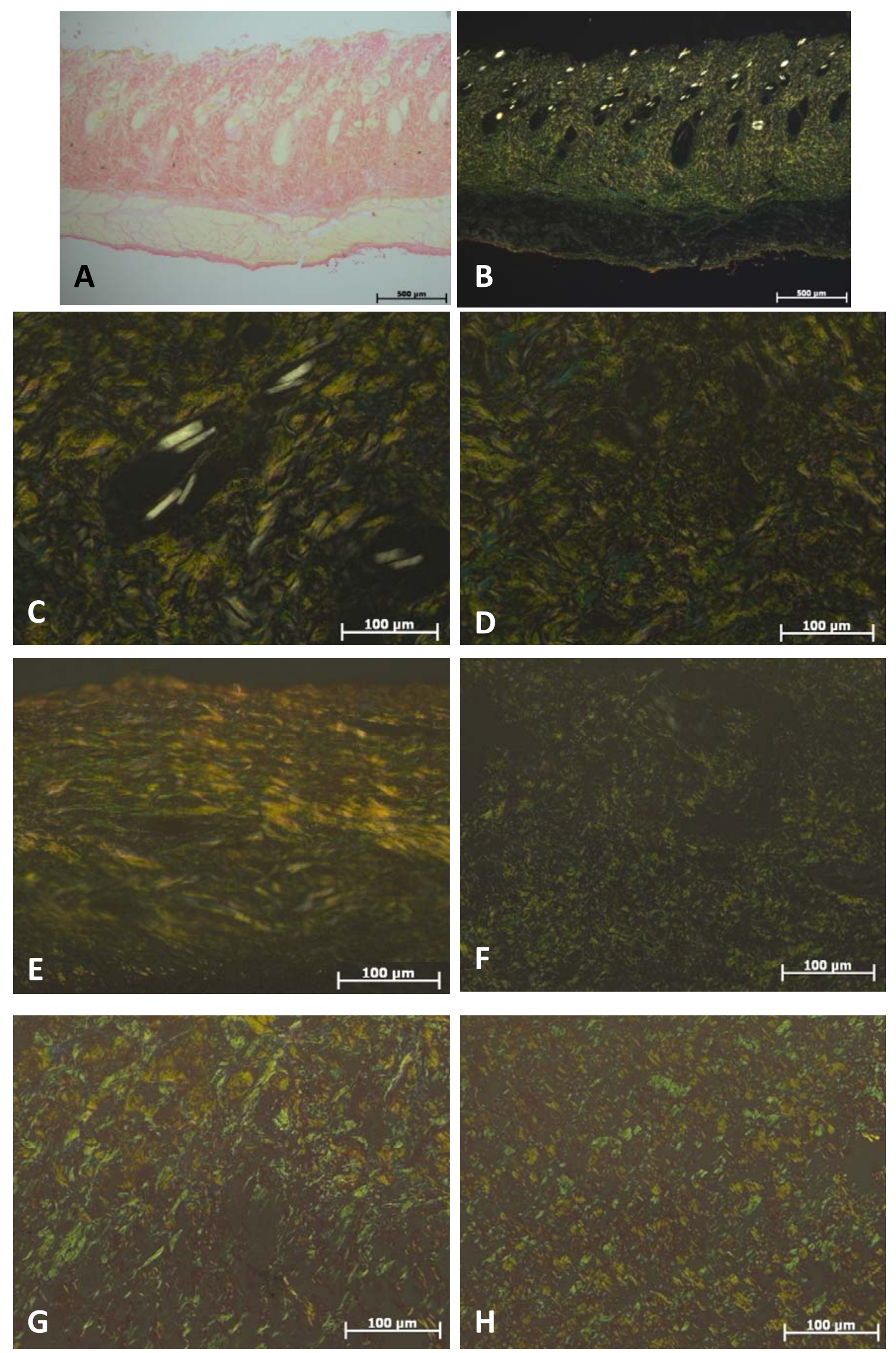

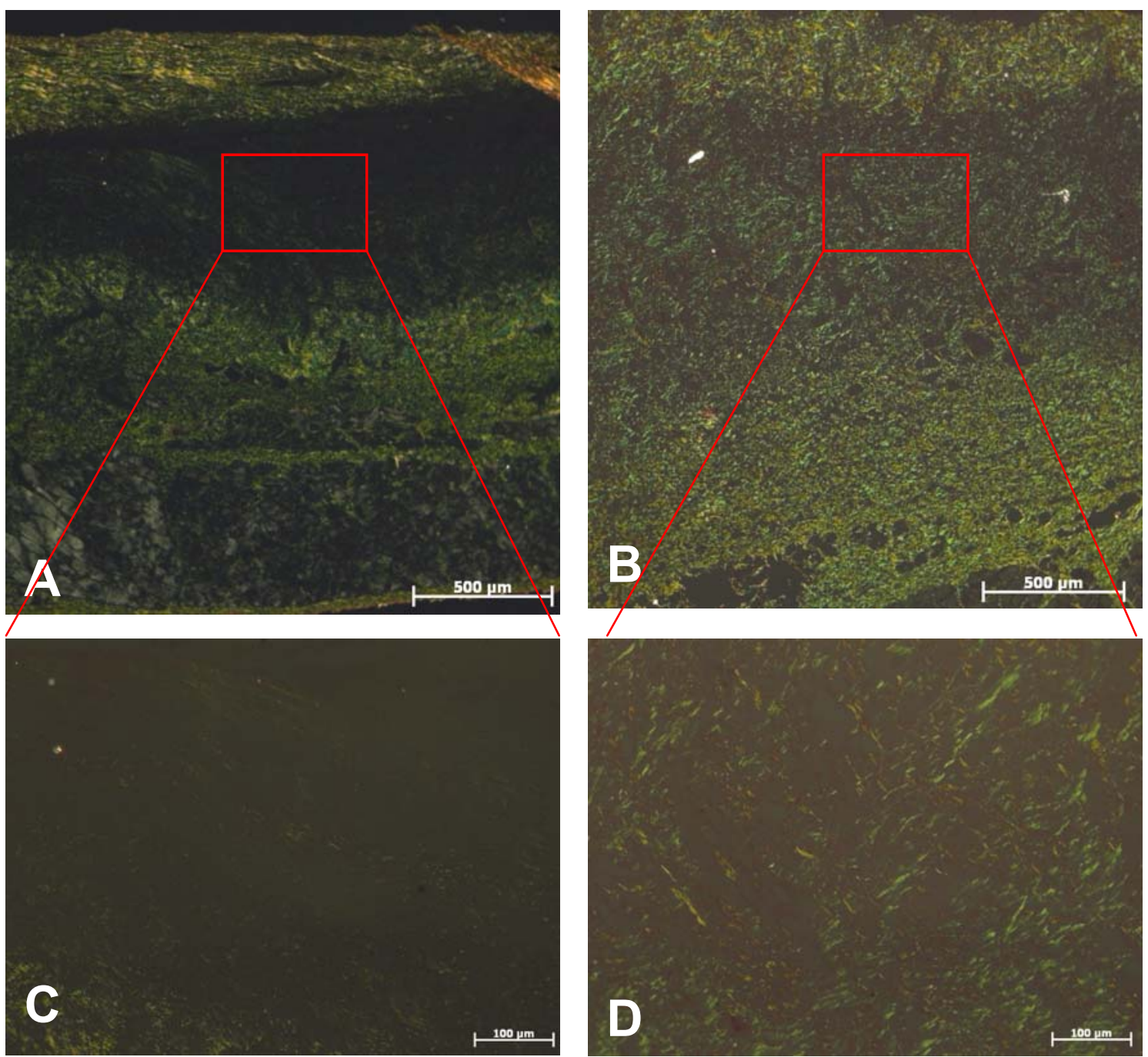

Figura 18 - Fotomicrografias do tecido de granulação dos animais dos grupos $\mathrm{GII}(14)$ (A, C), GIII(14) (B, D): Notar no tecido de granulação a malha regular de fibras colágenas, principalmente do tipo III, nos animais do grupo GIII, não observado nos animais do grupo Gll. Técnica de coloração: Picrosírius 


\subsubsection{Aspectos Ultraestruturais}

A análise sob microscopia eletrônica de varredura (MEV) permitiu verificar os aspectos tridimensionais da estrutura do tegumento dos animais. Desta forma, confirmou-se a constituição bem definida de suas camadas, desde a epiderme até a camada muscular do músculo panniculus carnosus. Além disso, tanto a disposição e a organização do colágeno, bem como a vascularização, puderam ser bem avaliadas com essa metodologia.

Através da MEV, observou-se nos animais dos grupos $\mathrm{Gl}(4)$ a descamação da epiderme onde esta apresentou-se em forma de flocos. Nos animais dos grupos GI(4) e GI(14) observou-se facilmente a junção dermoepidérmica e a divisão entre a derme papilar e a derme reticular, característica não observada na microscopia de luz, onde notou-se que, as fibras colágenas na derme papilar são mais delgadas e mais numerosas quando comparadas com a derme reticular, a qual apresenta fibras colágenas mais espessas. Além da organização destas estruturas, identificou-se que na região imediatamente subepidérmica, as delgadas fibras colágenas correm paralelamente às camadas da epiderme, tornando-se mais espessas e com aspecto mais entrelaçado, à medida que se aprofundam na derme. Evidenciou-se ainda nesta região, a presença de folículos pilosos e poucos vasos sanguíneos.

Relativamente a GII(4) e GII(14), a região da derme papilar apresenta fibras colágenas densamente arranjadas, sendo que nos animais do grupo GII(14) ocorre um tecido de granulação compactado e com aspecto endurecido. Nos animais do grupo GIII, nota-se em GIII(4) um arranjo colágeno mais frouxo e melhor organizado nos terços superficial e médio da derme, quando comparados aos animais do grupo GII(4), e ainda notou-se a presença de vasos sanguíneos. Tais aspectos foram mais evidentes nos animais do grupo GIII(14) que apresentaram o tecido de granulação bem desenvolvido, ou seja, mais maduro, constituído por uma malha pantográfica de tecido conjuntivo frouxo, infiltrada por vasos sangüíneos e presença de neoformação colágena (Figura 19). 


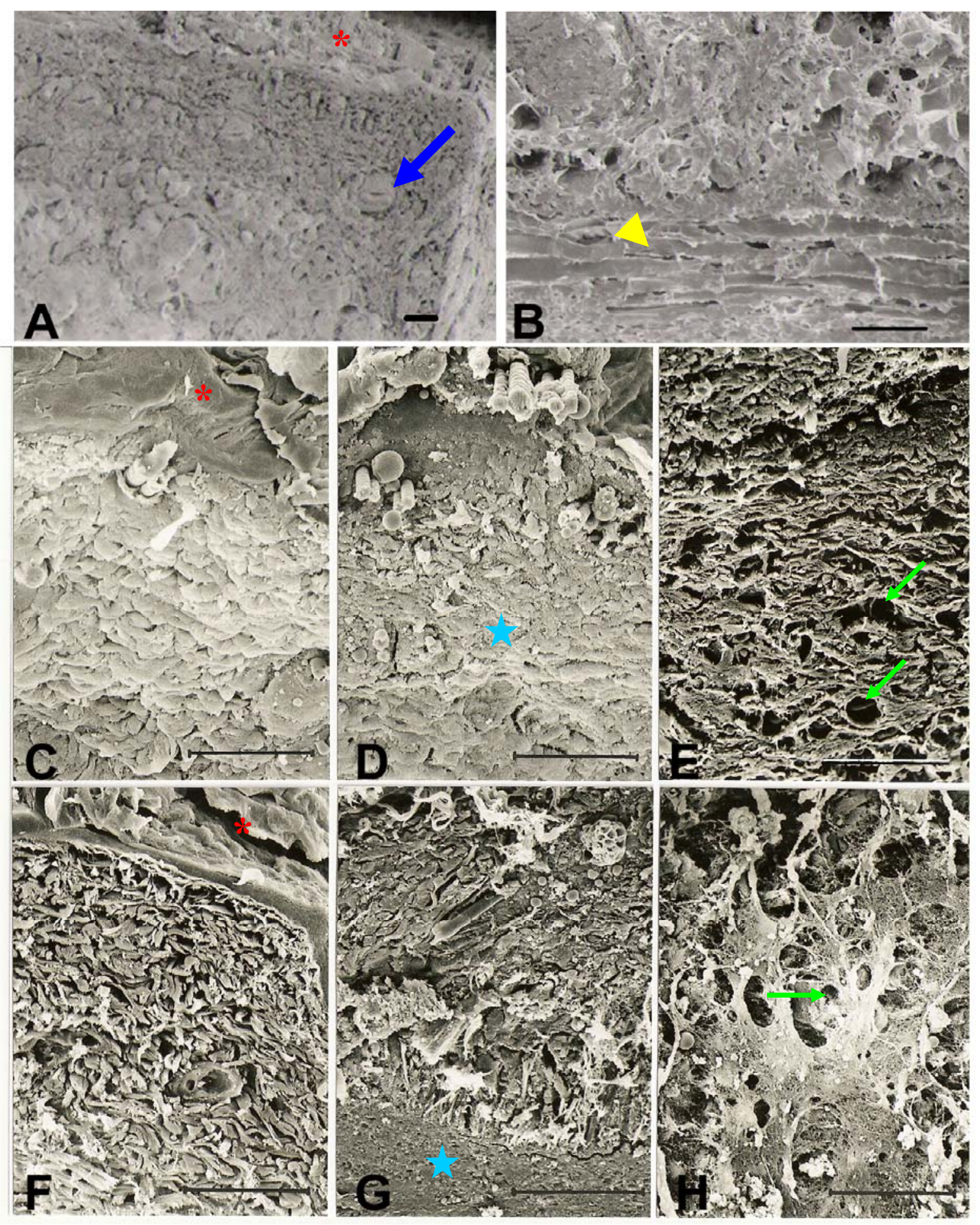

Figura 19 - Eletromicrografias de varredura das camadas do tegumento dos animais dos grupos GI (A, B, C e F), GII (D, G) e GIII (E, H): Notar a constituição bem definida das camadas, desde a epiderme $\left({ }^{*}\right)$ até a camada muscular (cabeça de seta) nos animais do grupo Gl. Observar a presença de folículos pilosos (seta espessa). Nos animais do grupo Gll, apresenta fibras colágenas densamente arranjadas e, tecido de granulação com aspecto endurecido (estrela). Nos animais do grupo GIII, observar a presença de vasos sangüíneos (seta delgada) 


\subsection{ANÁLISE QUANTITATIVA}

Foi avaliado quantitativamente o peso dos animais, a espessura da derme, a espessura do tecido de granulação e espessura total do tegumento dos animais. Ainda foi avaliado a $V_{v}$ das fibras elásticas e a $V_{v}$ das fibras colágenas presente no tecido de granulação.

\subsubsection{Peso dos Animais}

Durante o período experimental, todos os animais ganharam peso. As variações dos pesos entre os diferentes grupos estão expressas nas tabelas 1, 2 e figuras 20, 21.

Tabela 1 - Média ( \pm dp) da variação entre os pesos inicial e final $(\mathrm{g})$ dos animais dos grupos de 4 dias $\left({ }^{*} p<0,05\right)$ - São Paulo - 2008

\begin{tabular}{cccc}
\hline \hline Parâmetros & GI(4) & GII(4) & GIII(4) \\
\hline \hline Variação entre & & & \\
pesos & $16 \pm 1,41^{*}$ & $3,3 \pm 0,58^{*}$ & $10,6 \pm 1,14^{*}$ \\
(Final - Inicial) & & & \\
\hline
\end{tabular}

Tabela 2 - Média ( $\pm \mathrm{dp}$ ) da variação entre os pesos inicial e final $(\mathrm{g})$ dos animais dos grupos de 14 dias $\left({ }^{*} p<0,05\right)$ - São Paulo - 2008

\begin{tabular}{cccc}
\hline \hline Parâmetros & GI(14) & GII(14) & GIII(14) \\
\hline \hline Variação entre & & & \\
pesos & $97,7 \pm 4,16^{*}$ & $67,3 \pm 1,53^{*}$ & $79,6 \pm 2,70^{*}$ \\
(Final - Inicial) & & & \\
\hline
\end{tabular}




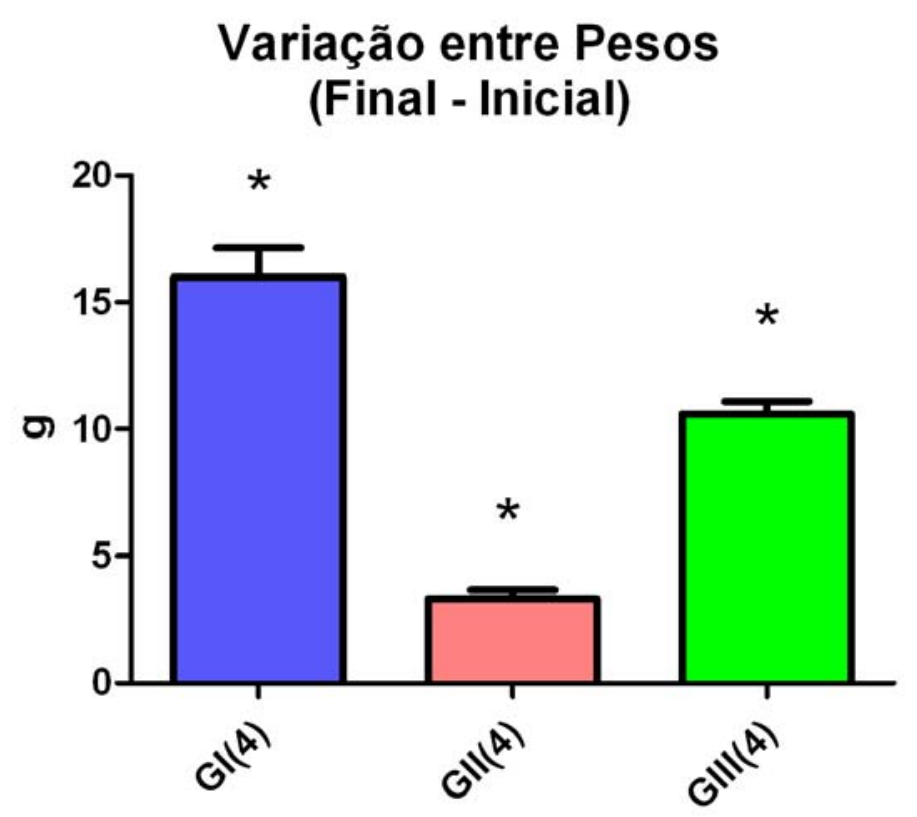

Figura 20 - Representação gráfica das comparações entre as variações de peso (final - inicial) dos animais dos grupos de 4 dias ( $\left.{ }^{*} p<0,05\right)$

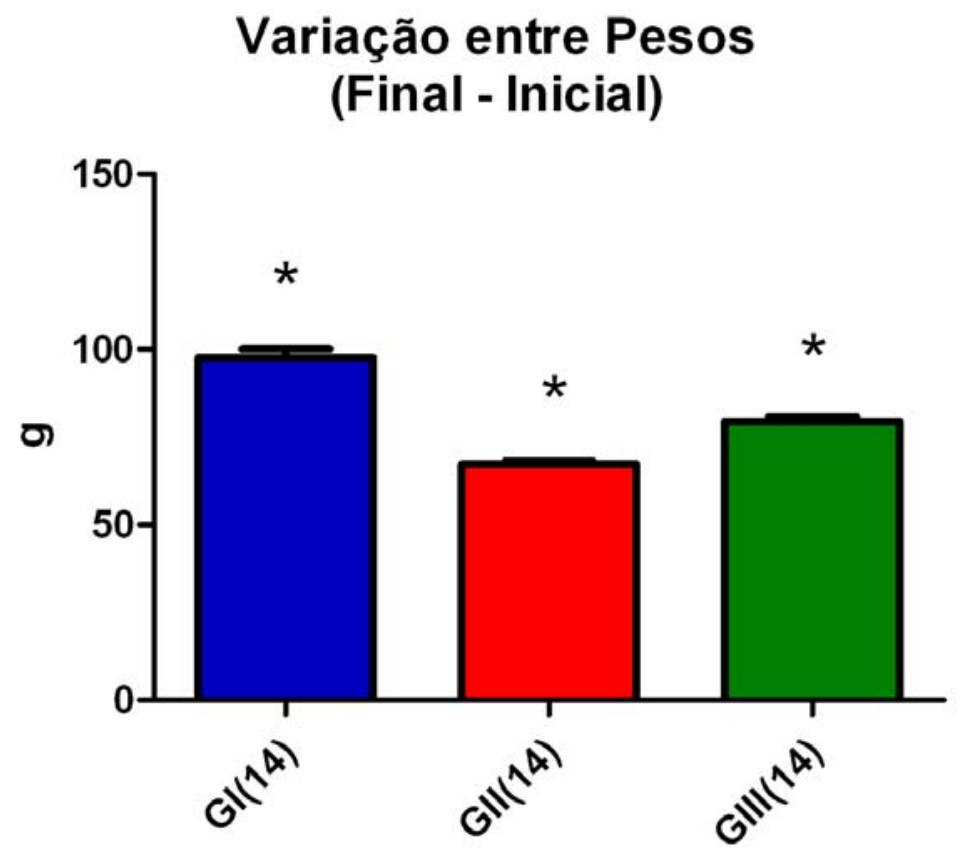

Figura 21 - Representação gráfica das comparações entre as variações de peso (final - inicial) dos animais dos grupos de 14 dias $\left({ }^{*} p<0,05\right)$ 
A análise das tabelas e figuras permite inferir que os animais dos grupos GII(4) e GIII(4) apresentaram variação de peso menor que $\mathrm{Gl}(4)$, sendo a variação de peso dos animais do grupo GIII(4) maior do que aquela observada nos animais do grupo Gll(4). Da mesma forma, os animais dos grupos GII(14) e GIII(14) apresentaram variação de peso menor que $\mathrm{Gl}(14)$, sendo que os animais do grupo GIII(14) apresentaram uma variação de peso maior que os animais do grupo GII(14).

\subsubsection{Histomorfometria}

As médias $( \pm \mathrm{dp})$ relativas às espessuras da derme e total do tegumento dos animais de 4 e 14 dias, respectivamente, estão expressas nas tabelas 3, 4 e figuras $22,23,24$ e 25.

Tabela 3 - Média $( \pm \mathrm{dp})$ das comparações entre as espessuras $(\mu \mathrm{m})$ da derme e total tegumento nos animais de quatro dias $\left({ }^{*} p<0,05\right)$ - São Paulo 2008

\begin{tabular}{cccc}
\hline \hline Parâmetros & GI(4) & GII(4) & GIII(4) \\
\hline \hline Espessura da & $851,31 \pm 187,42^{*}$ & $885,36 \pm 100,19$ & $1136,20 \pm 379,58$ \\
Derme & & & \\
Espessura Total & $1216,17 \pm 102,89^{*}$ & $1676,63 \pm 150,46$ & $1681,62 \pm 611,13$ \\
\hline
\end{tabular}

Tabela 4 - Média ( $\pm \mathrm{dp}$ ) das comparações entre as espessuras $(\mu \mathrm{m})$ da derme e total tegumento nos animais de quatorze dias $\left({ }^{*} p<0,05\right)$ - São Paulo 2008

\begin{tabular}{cccc}
\hline \hline Parâmetros & GI(14) & GII(14) & GII(14) \\
\hline \hline Espessura da & $1103,31 \pm 85,75^{*}$ & $1112,29 \pm 155,71$ & $1443,54 \pm 118,64$ \\
Derme & & & \\
Espessura Total & $1463,40 \pm 12,74^{*}$ & $1792,17 \pm 341,15$ & $2180,70 \pm 175,13$ \\
\hline
\end{tabular}




\section{Espessura da Derme}

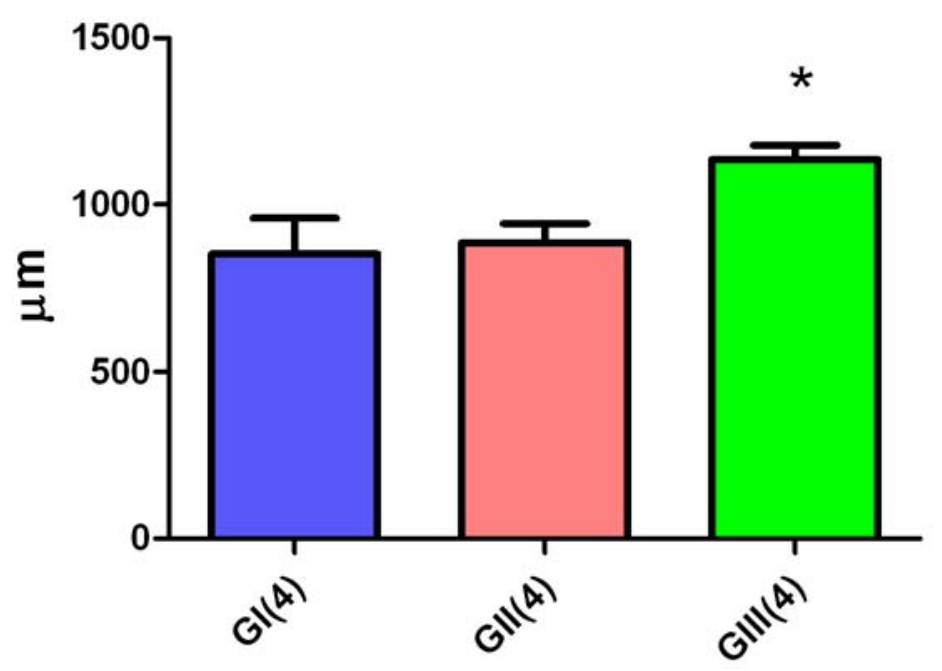

Figura 22 - Representação gráfica das comparações entre as espessuras $(\mu \mathrm{m})$ da derme nos animais de quatro dias $\left.{ }^{*} p<0,05\right)$

\section{Espessura da Derme}

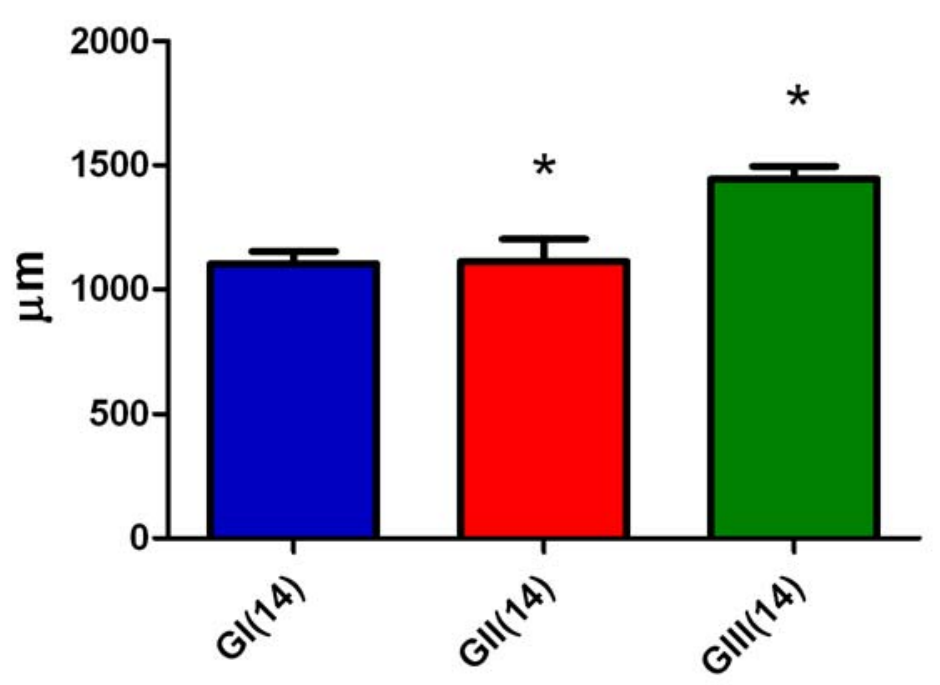

Figura 23 - Representação gráfica das comparações entre as espessuras $(\mu \mathrm{m})$ da derme nos animais de quatorze dias $\left({ }^{*} p<0,05\right)$ 


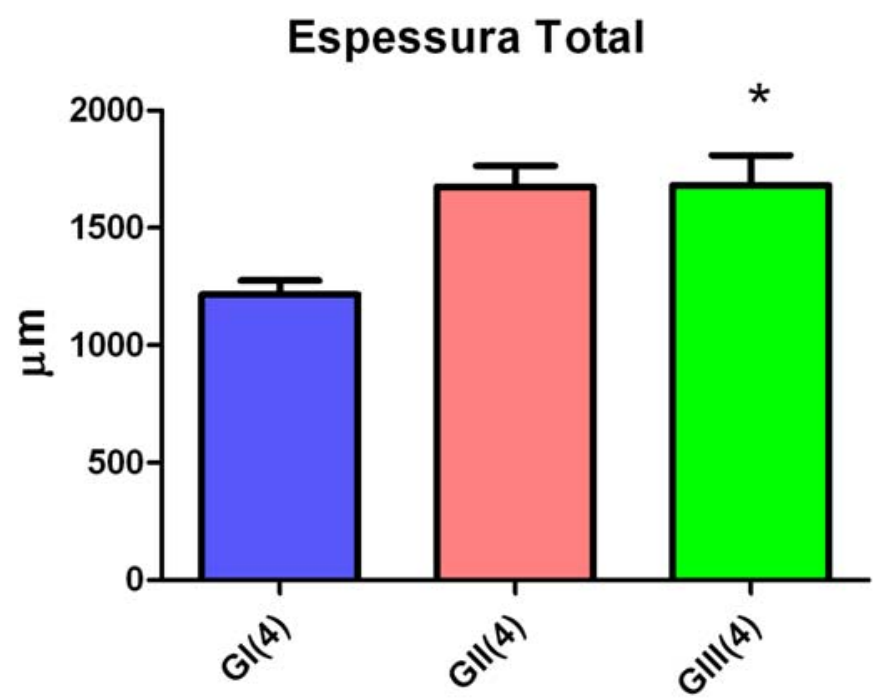

Figura 24 - Representação gráfica das comparações entre as espessuras totais do tegumento $(\mu \mathrm{m})$ nos animais de quatro dias $\left({ }^{*} p<0,05\right)$

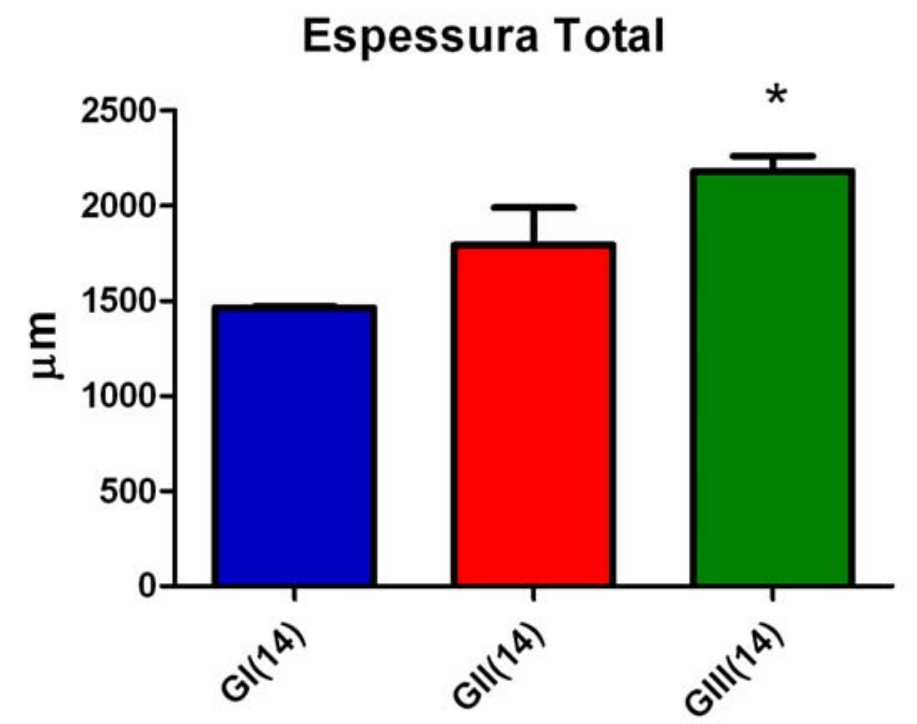

Figura 25 - Representação gráfica das comparações entre as espessuras totais do tegumento $(\mu \mathrm{m})$ nos animais de quatorze dias $\left({ }^{*} p<0,05\right)$ 
A análise das tabelas e figuras anteriores permite inferir que, os animais dos grupos GIII(4) apresentaram espessura da derme maior que GI(4), sendo que os animais do grupo GII(4) não apresentam diferença estatística significante em relação aos animais dos grupos GI(4) e GIII(4). Desta mesma forma, os animais do grupo GIII(14) apresentaram espessura da derme maior que GI(14) e GII(14).

Os animais do grupo GIII(4) apresentaram espessura total do tegumento maior que Gl(4), sendo que os animais do grupo Gll(4) apesar de se manifestar praticamente igual aos animais do grupo GIII, não apresentam diferença estatística significante em relação aos animais dos grupos GI(4) e GIII(4).

Os animais do grupo GIII(14) apresentaram espessura total do tegumento maior que $\mathrm{GI}(14)$, sendo que os animais do grupo GII(14) não apresentam diferença estatística significante em relação aos animais dos grupos GI(14) e GIII(14).

As médias ( \pm DP) relativas à espessura do tecido de granulação estão expressas na tabela 5 e figura 26.

Tabela 5 - Média ( $\pm \mathrm{dp}$ ) da comparação entre as espessuras $(\mu \mathrm{m})$ do tecido de granulação dos animais dos grupos Gll e GIII de quatorze dias (* p<0,05) - São Paulo - 2008

\begin{tabular}{ccc}
\hline \hline Parâmetros & GII(14) & GIII(14) \\
\hline \hline Espessura do & & \\
Tecido de & $423,83 \pm 43,80$ & $514,74 \pm 51,10^{*}$ \\
granulação & & \\
\hline
\end{tabular}




\section{Espessura do Tecido de Granulação}

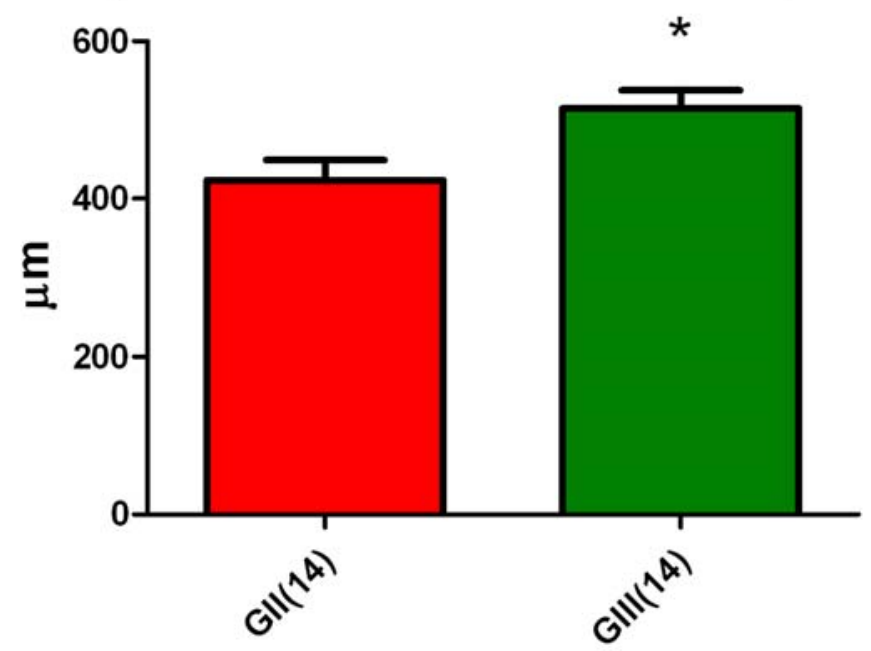

Figura 26 - Representação gráfica da comparação entre as espessuras $(\mu \mathrm{m})$ do tecido de granulação nos animais GII e GIII de quatorze dias ( ${ }^{*} p$ $<0,05)$

O tecido de granulação somente foi evidenciado nos animais do grupo GII(14) e GIII(14). A análise da tabela e da figura anterior permite inferir que, os animais do grupo GIII(14) apresentaram espessura do tecido de granulação maior que GII(14).

\subsubsection{Estereologia}

As médias $( \pm \mathrm{DP})$ relativas à densidade de volume das fibras elásticas estão expressas na tabela 6,7 e figura $27,28$.

Tabela 6 - Média ( \pm dp) das comparações das densidades de volume (\%) das fibras elásticas dos animais de quatro dias $\left({ }^{*} p<0,05\right)$ - São Paulo - 2008

\begin{tabular}{cccc}
\hline Parâmetros & GI(4) & GII(4) & GIII(4) \\
\hline \hline $\begin{array}{c}\text { Vv das Fibras } \\
\text { Elásticas }\end{array}$ & $30 \pm 5,29$ & $37,33 \pm 3,21^{*}$ & $27,80 \pm 2,86$
\end{tabular}


Tabela 7 - Média ( \pm dp) das comparações das densidades de volume (\%) das fibras elásticas dos animais de quatorze dias $\left({ }^{*} p<0,05\right)$ - São Paulo - 2008

\begin{tabular}{cccc}
\hline \hline Parâmetros & GI(14) & GII(14) & GIII(14) \\
\hline \hline $\begin{array}{c}\text { Vv das Fibras } \\
\text { Elásticas }\end{array}$ & $27,67 \pm 3,79$ & $33 \pm 4,58$ & $32 \pm 1,58$
\end{tabular}

Fibras Elásticas

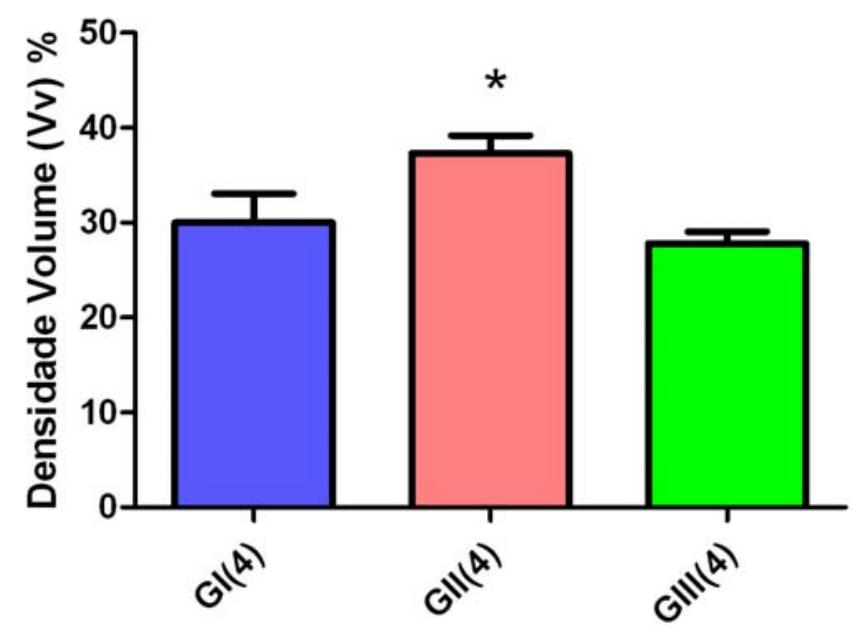

Figura 27 - Representação gráfica das comparações entre as densidades de volume (\%) das fibras elásticas nos animais de quatro dias ( $\left.{ }^{*} p<0,05\right)$

\section{Fibras Elásticas}

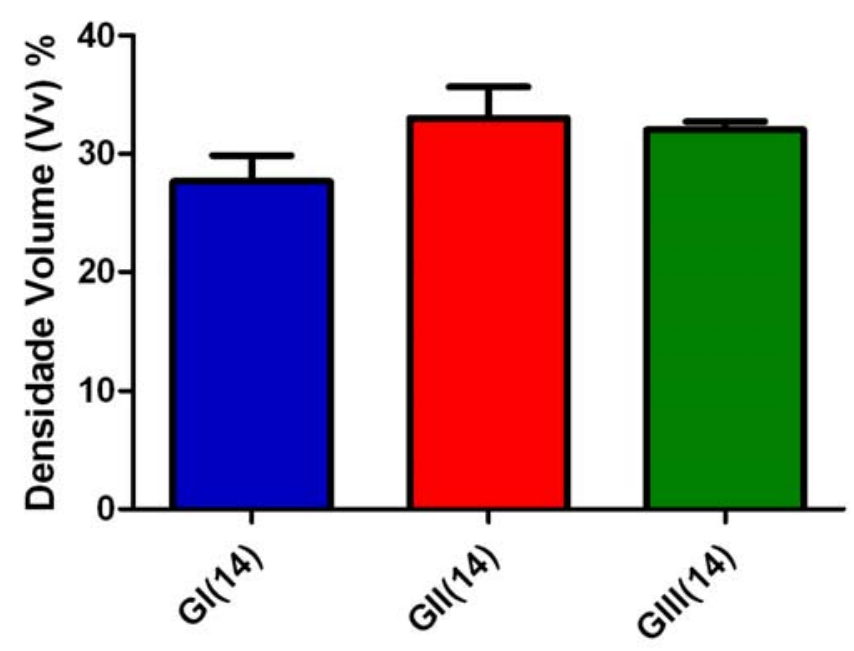

Figura 28 - Representação gráfica das comparações entre as densidades de volume (\%) das fibras elásticas nos animais de quatorze dias $\left({ }^{*} p<0,05\right)$ 
A análise da tabela e figura anterior permite inferir que, os animais do grupo GII(4) apresentaram $V_{v}$ maior que GIII(4), sendo que os animais do grupo GI(4) não apresentam diferença estatística significante em relação aos animais dos grupos GII(4) e GIII(4).

As médias ( \pm DP) relativas à densidade de volume do tecido de granulação estão expressas na tabela 8 e figura 29.

Tabela 8 - Média $( \pm \mathrm{dp})$ da avaliação da Densidade de volume (\%) do tecido de granulação dos animais dos grupos Gll e GIII de quatorze dias 14 (* $\mathrm{p}<0,05)$ - São Paulo - 2008

\begin{tabular}{ccc}
\hline Parâmetros & GII(14) & GIII(14) \\
\hline \hline $\begin{array}{c}\text { Vv do Tecido de } \\
\text { Granulação }\end{array}$ & $39,67 \pm 7,64$ & $51,20 \pm 4,97^{*}$ \\
\hline
\end{tabular}

\section{Granulação}

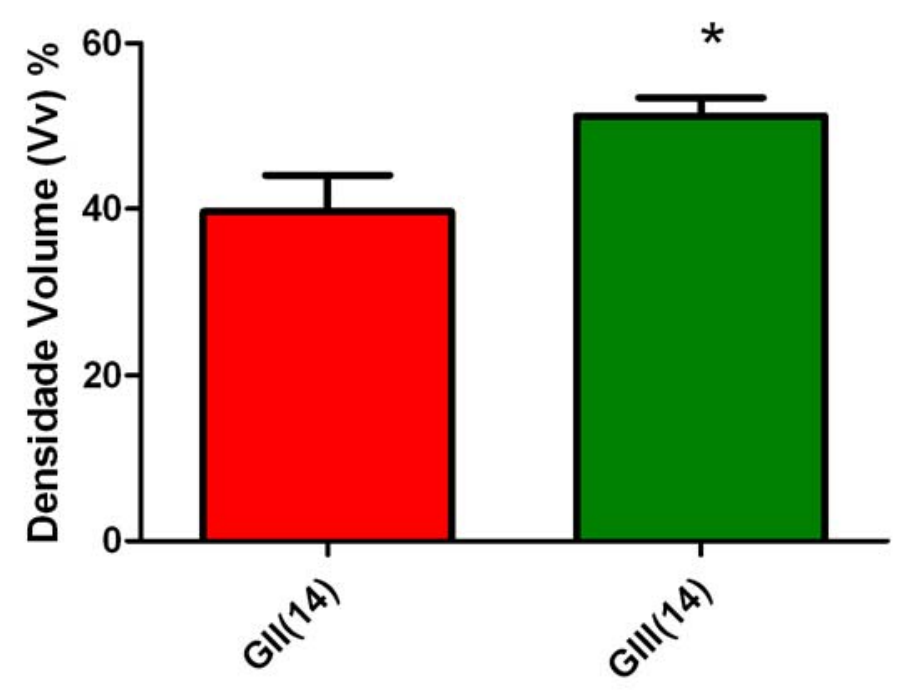

Figura 29 - Representação gráfica da comparação entre a Densidade de volume (\%) do tecido de granulação nos animais GII e GIII de quatorze dias ( ${ }^{*} \mathrm{p}$ $<0,05$ ) 
Conforme observado na histomorfometria, igualmente verificou-se um aumento do $V_{v}$ do Tecido de granulação nos animais do grupo GIII(14) em relação aos animais do grupo GII(14).

As médias $( \pm \mathrm{DP})$ relativas à densidade de volume das fibras colágenas presente no tecido de granulação estão expressas na tabela 9.

Tabela 9 - Média ( $\pm \mathrm{dp}$ ) da avaliação da Densidade de volume (\%) das fibras colágenas presente no tecido de granulação dos animais do grupo GIII(14) - São Paulo - 2008

\begin{tabular}{cc}
\hline \hline Parâmetros & GIII(14) \\
\hline \hline Vv do Colágeno & \\
no Tecido de & $21 \pm 3,87$ \\
Granulação & \\
\hline
\end{tabular}

Como já observado qualitativamente, o tecido de granulação somente foi evidenciado nos animais do grupo GII(14) e GIII(14), porém não foram realizadas comparações estatística para estes grupos, uma vez que não encontramos neoformação colágena no tecido de granulação dos animais do grupo GII(14). 


\section{DISCUSSÃO}

Dada a grande quantidade de informações decorrentes dos resultados aqui obtidos, com o intuito de facilitar a compreensão, optou-se pela exposição comparativa com a literatura pertinente em itens expostos a seguir.

\subsection{MODELO ANIMAL}

O animal mais utilizado em estudos experimentais relacionados à pele é o porco, pois apresenta grande analogia com a estrutura, espessura e cicatrização da pele humana (MONTAGNA; YUN, 1964; DOUGLAS, 1972; MEYER et al., 1978; BRANS et al., 1994; NANNEY et al., 1996). Entretanto, deve-se considerar o grande porte destes animais e as dificuldades decorrentes de sua obtenção, manipulação e manutenção. Segundo Kistler et al. (1988) e Aksoy et al. (2002), muitos estudiosos usam animais de menor porte, como por exemplo o rato da linhagem Wistar, pela facilidade na obtenção e manipulação experimental em laboratório. Além disso, esse modelo animal caracteriza-se pelo índice de mortalidade baixa, o que, de certa forma, diminui os custos relativos a uma pesquisa onde um maior número de animais se faz necessário.

Todavia, segundo Auervauld (1999) e Graf (2000), sob o aspecto histológico, a pele dos ratos não apresenta uma divisão clara entre a derme papilar e a reticular, como é facilmente distinguível na pele de humanos. Em vista disso, métodos que utilizam estes compartimentos anatômicos para comparar a profundidade das lesões podem ser falhos e poucos reprodutíveis. Outra diferença importante é a quantidade de fibras elásticas na derme, que é bem menor nos ratos do que nos humanos, um fator importante em estudos experimentais que visam processos de cicatrização (NORONHA et al., 2001b). Ainda, deve-se considerar que a pele de roedores é marcadamente diferente da pele humana, em termos de distribuição dos folículos pilosos, uma vez que o rato caracteriza-se por apresentar o dorso altamente piloso, o que poderia exercer um efeito protetor não observado em humanos. Além disso, a presença de uma camada muscular (panniculus carnosus), que proporciona o 
fechamento do ferimento predominantemente por via de contração do que por reepitelização, também tem sido referida como um fator que pode alterar as comparações desse modelo animal com humanos (MONTANDON, et al., 1977; AKSOY et al., 2002; NORONHA et al., 2001b; PAPP et al., 2004) .

Certos autores descrevem que as áreas próximas a folículos pilosos apresentam danos menores e devem, portanto, ser evitadas, mormente quando se procede a processos morfométricos. (ROSS et al., 1996; AUERSVAULD, 1999; FRANÇA, 1999; ROSS et al., 1999; NORONHA et al., 2001a,b,c). Por esses fatores, selecionou-se na presente pesquisa para análise e quantificação das fibras do sistema elástico, o terço médio da derme, a fim de evitar o viés uma vez que, na região subepidérmica ocorreu grandes alterações, o que dificultaria comparações. Portanto, a principal preferência pelo terço médio, residiu-se no fato de esta ser uma região de transição entre a derme superficial e a derme profunda, onde foram verificados, nesta camada de eleição, estruturas compatíveis com as partes da derme superficial e profunda.

\subsection{PERÍODO DE EXPOSIÇÃO À LTE E MODELO EXPERIMENTAL}

O tipo de lesão térmica corporal escolhido dentre os diferentes existentes, foi aquele provocado por escaldamento (LTE), por ser este um modelo consagrado na literatura pertinente às lesões térmicas em geral. (HERBERT; TURINSKY et al., 1982; NEWMAN et al., 1982; GONÇALVEZ et al., 1991; BEVILACQUA et al., 1997). Além disso, fatores considerados favoráveis, como permitir mais facilmente um adequado controle da área da superfície a ser lesada (e posteriormente tratada) e ainda, por este tipo de lesão ser o mais comum no Brasil, onde $70 \%$ de todas as queimaduras ocorrem em casa e $50 \%$ dessas vítimas serem crianças (a maioria com baixo nível sócio-econômico), contribuíram para que a LTE fosse eleita como um modelo experimental adequado (PICCOLO, 2002; OLIVEIRA et al., 2007).

A opção pelo período de 4 dias para o primeiro sacrifício dos animais e para as primeiras avaliações histológicas, histomorfométricas e estereológicas, seguiu dados previamente descritos, uma vez que este período coincide com as primeiras etapas da reparação tecidual, ou seja, os primeiros eventos fisiológicos, como início 
da proliferação celular e da formação do tecido de granulação (ABLA; ISHIZUKA, 1995; SANTOS, 2000), sendo, estes eventos considerados como parte da primeira fase da cicatrização, ou seja, da fase inflamatória, onde observou-se nesse período, os principais eventos fisiológicos (hemostasia, quimiotaxia leucocitária e diapedese, fagocitose e liberação de fatores de crescimento), fase de proliferação celular (dividida em outros três eventos: angiogênese, proliferação fibroblástica e epitelização), e aquela conhecida como formação do tecido conjuntivo (que, a partir do tecido de granulação, tem como principal característica a presença de fibroblastos, produtores de matriz extracelular, colágeno e glicosaminoglicanos). (KOHN, 1992; SPRINGER, 1994; THOMAS et al., 1995).

Da mesma forma, a opção pelo período de 14 dias, como fase final do momento experimental, deveu-se ao fato de clinicamente, ser esse o tempo necessário para a ocorrência dos debridamentos dos ferimentos (WALDEN et al., 2000; FAY et al., 2001). Ainda, considerou-se ser esse período, tempo suficiente para as primeiras observações e avaliações acerca da eficácia da utilização da BML como reparador tecidual. Todavia, ficou claro que 14 dias não foi tempo suficiente para a recuperação total da ferida, tanto nos animais do grupo GIII como, em menor grau, nos animais do grupo Gll.

Em muitos modelos experimentais de cicatrização de feridas, somente a reepitelização tem sido tomada como objetivo final da cicatrização. Embora seja útil em estudos experimentais preocupados com a migração de queratinócitos, ele não se reporta ao reparo dérmico da ferida (HOM, 1995), pois o aspecto tensivo da pele cicatrizada é inadequado ao momento da pavimentação epitelial. Além disso, a remodelação do colágeno, e outros eventos que levam à ótima maturação da cicatriz, ocorrem por meses após a reepitelização estar terminada (SAARIALHOKERE et al., 1992).

O modelo experimental aqui utilizado, oriundo de estudos realizados por Newman et al. (1982), mostrou-se, mais uma vez, eficiente para produzir uma queimadura que alcançasse as proporções da derme superficial e média o que foi considerado adequado e suficiente para inferir as primeiras considerações acerca da eficácia da BML.

Outros estudiosos alcançaram estas mesmas proporções utilizando contato com água à $92^{\circ} \mathrm{C}$ por um tempo de exposição de 15 segundos (CUTTLE et al., 2006). A relação entre temperatura, duração e profundidade da lesão foi 
primeiramente descrita por Moritz e Henriques em 1947 (MORITZ; HENRIQUES, 1947), que utilizaram água quente para queimar uma porção da pele e examinar a necrose da epiderme como um indicador de profundidade da lesão. Esses autores relataram temperaturas e durações diferentes daquelas aqui empregadas como, por exemplo, a observação de que a exposição da pele por 1 segundo a uma temperatura de $90^{\circ} \mathrm{C}$ foi suficiente para causar uma lesão trans-epidermal e, com 5 segundos, a formação de uma lesão de segundo grau. Como se depreende, a literatura relata que, durante a criação de modelos experimentais, observa-se alguma variabilidade na profundidade da queimadura, no tipo de ferimento e nas proporções de cura em um mesmo modelo animal (PAPP et al., 2004). Clinicamente, feridas por queimaduras mostram variabilidade dentro de um mesmo indivíduo, em que algumas áreas são mais profundamente lesadas que outras, mesmo sofrendo o mesmo estímulo (IREI et al., 1986). Pelo exposto, não se descartou na presente pesquisa, a possibilidade de que tais fatores possam ter ocorrido; entretanto, se existem autores que defendem a existência de diferentes métodos para mensuração de cicatrizes, da mesma forma não há um consenso em como avaliar as medidas em um determinado tipo de ferimento e comparar com outros (CUTTLE et al., 2006).

\subsection{UTILIZAÇÃO DA BIOMEMBRANA DE LÁTEX NATURAL (BML)}

Os efeitos de medicações sistêmicas em cicatrização de feridas são complexos e controversos. Estudos em animais sugerem que algumas drogas podem interferir em fases específicas da cicatrização de feridas e diminuir a sua intensidade (FERGUSON, 1982). Infelizmente, estudos clínicos controlados em seres humanos são inespecíficos. Na prática médica, muitos desses agentes não produzem, clinicamente, efeitos adversos noticiados no reparo de feridas (DIEGELMANN et al., 1979); as exceções incluem anticoagulantes, glicocorticóides e agentes antineoplásicos. Os anticoagulantes promovem sangramentos e formação de hematomas; corticosteróides inibem muitos dos aspectos da cicatrização diminuindo a inflamação, a síntese de proteínas e de colágeno, e a proliferação epidérmica e, ainda, interferindo nos mecanismos de defesa do hospedeiro e promovendo o catabolismo do colágeno (FERGUSON, 1982). As propriedades 
físicas e mecânicas dos biomateriais podem ser determinadas por meio de métodos padronizados e descritos de forma objetiva (MUHART et al., 1999; TARLOW et al., 2001). A resposta biológica ou morfométrica do material usado na área afetada é avaliada de forma menos definida, por meio do infiltrado celular, da quantidade de fibrose e do grau de vascularização. Além disso, a resposta biológica vai depender se o material é absorvível ou não, sintético ou natural, se é possuidor de ligações químicas ou não (LOPES et al., 2004).

Uma condição necessária para que um material seja considerado ideal é a sua resistência às infecções (PAULO, 2005). O mercado oferece uma diversidade de produtos para tratamento de queimaduras, o que tem provocado insegurança nos profissionais da saúde sobre qual opção é o mais indicado. Vale considerar que a literatura apresenta alguns questionamentos sobre o tratamento das queimaduras ainda sem respostas, e controvérsias que merecem ser esclarecidas. Segundo os dados disponíveis, $25 \%$ do atraso na alta de pacientes em hospitais podem ser atribuídos à falha no tratamento de ferida (WITTE; BARBUL, 2002; OLIVEIRA et al., 2005). Em adição, alguns estudiosos mencionam a escassez de informações específicas, acerca da indicação e efeitos adversos dos produtos convencionalmente utilizados em queimadura, de maneira que seja possível relacionar estas informações com o tipo e a fase da queimadura (WARD; SAFLLE, 1995). Assim, é preciso conhecer a eficiência de cada produto frente à diversidade de situações. Cabe destacar que o sucesso do tratamento depende, dentre outros fatores, da criteriosa escolha, bem como, da adequada utilização dos produtos selecionados (FERREIRA et al., 2003a).

A escolha pela BML foi devido às observações clínicas e experimentais com resultados positivos citadas na literatura; porém, nada ou muito pouco foi verificado do tratamento com a mesma sobre o leito de ferimentos a base de queimaduras. $O$ material, de fácil aquisição, não apresentou dificuldades técnicas quanto à sua implantação. Por exibir uma superfície lisa e de consistência macia, permitiu a inserção da agulha sem tensão; por ser elástico, não foram encontradas dificuldades em ajustá-lo ao leito receptor. Por ser de origem vegetal, a BML não exibe o potencial de transmissão de doenças infecciosas (PINHO et al., 2004) mostrando-se biocompatível em todos os experimentos já realizados, sem nenhum tipo de reação alérgica (FORREST, 1983; MRUÉ, 2000). Os resultados observados na presente 
pesquisa estão de acordo com a literatura, uma vez que não se evidenciou nenhum tipo de processo inflamatório agudo.

Acredita-se que a BML apresente importantes propriedades biológicas, tais como: atividade neoangiogênica, promoção de adesão celular e formação de matriz extracelular (MRUÉ, 1996; MRUÉ, 2000; ANDRADE, 2007; DELEGUIDE, 2008). Em estudos experimentais, a BML favoreceu o reparo de defeitos parciais de esôfago (MRUÉ, 1996; MRUÉ, 2000) e de ressecções extensas de parede abdominal (MRUÉ 1996), demonstrando, inclusive, capacidade de substituição parcial de pericárdio (SADER et al., 2000). Também já foi utilizada com sucesso, em cirurgias reconstrutoras de membrana timpânica (OLIVEIRA et al., 1999), em úlceras de membros inferiores (FRADE et al., 2001; MENTE, 2002), arterioplastia experimental no cão (FREITAS, 2001), meringoplastia (OLIVEIRA, et al.; 2003), indutor da cicatrização conjuntival em coelhos (PINHO et al.; 2004) e, finalmente, caracterizada como um efetivo método para cobertura da cavidade mastóidea facilitando epitelização e renovação desta cobertura (SOUSA, 2007).

\subsection{AVALIAÇÃO DO PESO}

Contrariando o que normalmente acontece com pacientes que sofrem queimaduras, no presente estudo observou-se que a massa final dos animais, nos três grupos (GI, GIl e GIII), foi maior que inicial. A idade dos animais (adultos com 60 dias), a área lesada menor que $30 \%(18 \%)$ do peso corporal total e, ausência aparente de qualquer processo inflamatório agudo ou de patologias, provavelmente são fatores somados que influenciaram nos resultados.

Segundo Ferreira (2003a), aspectos como, por exemplo, a localização, profundidade, extensão, presença ou não de infecção, agente causador do trauma, estado nutricional dos pacientes, presença de doenças crônicas degenerativas e faixa etária, afetam o processo de cicatrização e influenciam na escolha do tratamento da ferida.

A Idade é um dos aspectos sistêmicos mais importantes, como co-fator de risco tanto para a lesão como para a sua manutenção, ao gerar um impacto no funcionamento de todos os sistemas fisiológicos corporais. A idade avançada está 
associada a uma série de alterações nutricionais, metabólicas, vasculares e imunológicas e, muitas vezes, as doenças crônicas, que tornam o indivíduo mais suscetível ao trauma e à infecção (SANTOS, 2000). Alguns estudos afirmam existir maior incidência de feridas crônicas em pacientes na faixa etária acima de 60 anos (ZINK et al.,1992; GONÇALVES, 1996; BLANES, 2002).

Observou-se ainda que na avaliação com quatro dias, a variação de peso foi visivelmente diferente, provavelmente devido ao estresse que os animais sofreram no período imediatamente pós-LTE, como perda de apetite. Já aos quatorze dias observou-se uma tendência ao equilíbrio quanto à variação de peso, provavelmente pela redução do quadro de estresse, onde os animais puderam se alimentar melhor.

\subsection{CONSIDERAÇÕES MORFOLÓGICAS}

A queimadura provoca um tipo de lesão de origem física, através do calor, provocando ablação com desnudamento da epiderme e exposição da derme, além de desnaturação protéica com necrose de coagulação do colágeno dérmico (NORONHA et al., 2001b). Estas lesões determinam o desencadeamento dos mecanismos de reação inflamatória, sendo os primeiros sinais a congestão, manifestada pelo eritema, e edema dos tecidos lesados (NORONHA et al., 2001b).

Observou-se que muitos modelos animais possuem ferimentos em diferentes regiões do corpo, porém, no presente estudo, foi produzido apenas um ferimento dorsal, uma vez que tem sido relatado que diferentes posições anatômicas de ferimentos no corpo podem produzir diferentes interpretações (HINRICHSEN et al., 1998).

Verificou-se que a LTE comprometeu toda a epiderme, a derme papilar e os terços superior e médio da derme reticular. O tempo e a temperatura de eleição (10 segundos; $85^{\circ} \mathrm{C}$ ) promoveu alterações graves nessas regiões, caracterizando uma queimadura de segundo grau, com reparação tecidual do tipo crônico e extensão do dano considerado como "ferida com perda parcial", como descrito por Cuttle et al. (2006).

Tem sido descrito que, clinicamente, a aparência imediata do ferimento de queimadura, pode fornecer um indicativo da profundidade da lesão. Assim, uma área 
pós escaldamento rosada é indicativo de um ferimento mais superficial; por outro lado, um ferimento cuja área mostra-se esbranquiçada, mas não empalidecida, indica uma lesão mais profunda (PAPP et al., 2004). No caso do modelo aqui utilizado, este último aspecto foi observado quando, imediatamente após a LTE, a área em questão apresentou-se elevada e esbranquiçada, circundada por uma zona hiperêmica, reforçando ainda mais a hipótese da formação de um ferimento de segundo grau.

De acordo com Abla e Ishizuka (1995) diversos eventos são notados imediatamente após a LTE, tais como uma vasoconstrição por 5 a 10 minutos, retração e perda de conexões das células endoteliais, e aumento da permeabilidade vascular (permitindo a passagem, para a ferida, de plasma, eritrócitos e leucócitos). Esta vasodilatação com extravasamento de elementos para o exterior do vaso forma um exsudato, traduzido clinicamente por tumor, calor, rubor e dor, cuja intensidade correlaciona-se com o tipo e grau de agressão. No presente estudo, a área lesada dos animais do grupo Gll que, do segundo ao quarto dia, exibiu um aumento progressivo de flictenas com eliminação de uma secreção levemente viscosa corrobora com a afirmação de que elementos sangüíneos extravasam para a ferida.

A organização da epiderme em camadas onde, à medida que as mais superficiais são eliminadas, restauram-se as camadas mais profundas por divisão celular (ARNOLD et al., 1994; NORONHA et al., 2001; FERREIRA et al., 2003b; ) foi aqui verificada à MEV, detectando-se uma descamação da camada mais superficial da epiderme (córnea), corroborando com as descrições de Dyce et al. (2004), que descreve a contínua renovação da epiderme, à medida que as células superficiais esfacelam em flocos.

A junção entre a epiderme e a derme é irregular. As projeções da derme (papilas dérmicas) que se encaixam em reentrâncias da epiderme (cristas epidérmicas) com função de aumentar a coesão entre ambas (MCGRATH et al., 1992; EURELL; FRAPPIER, 2006) não foi verificada nitidamente na pele do rato. Além disso, a profundidade da LTE lesou gravemente a o terço superficial da derme nos animais do grupo GII, exibindo um tecido com aparência necrótica, como descrito por Cuttle et al. (2006).

Como na derme (definida como o tecido conjuntivo onde se apóia a epiderme e une a pele à hipoderme) situam-se os anexos da pele, vasos sangüíneos, vasos linfáticos e nervos (ARNOLD et al., 1994) a mesma foi objeto de observação mais 
minuciosa na presente pesquisa. Histologicamente a derme de roedores é constituída por tecido conjuntivo denso formado por fibras colágenas dos tipos I e III, pequena quantidade de fibras elásticas (FERREIRA et al., 2003b), e apresenta um estrato superficial (camada papilar) e outro profundo (camada reticular), onde não observa-se, nesses animais, uma divisão clara entre ambas, através de métodos histológicos convencionais (AUERVAULD, 1999 e GRAF 2000).

$\mathrm{Na}$ presente pesquisa, verificou-se uma reorganização da derme muito mais rápida e bem melhor nos amimais do grupo GIII, quando comparados àqueles do grupo GII. Os exames histológico, histomorfométrico e estereológico quanto à espessura do processo inflamatório (tecido de granulação) evidenciaram superioridade dos animais do grupo GIII(14) em relação aos animais do grupo GII(14), o que levou-se a interpretar como, altamente positiva, a maior espessura do tecido de granulação em GIII(14), por apresentar maior densidade de vasos neoformados e um equilíbrio entre as fibras colágenas dos tipos I e III, aspectos estes, semelhantes ao verificado nos animais do grupo (GI). Tais resultados estão de acordo com Mendes Junior et al. ( 2007) e Abla e Ishizuka (1995). Nos animais do grupo GIII(14), o tecido de granulação aparece mais basófilo sob coloração de H.E., sendo facilmente distinguido dos demais tecidos da derme, por apresentar uma aparência mais celular, conforme descrito por Cuttle et al. (2006).

Por volta do segundo ou terceiro dia pós-LTE ocorre uma reparação do tecido conjuntivo, com a migração e divisão das células endoteliais e a formação do tecido de granulação constituído por colágeno, fibronectina e ácido hialurônico, com densa infiltração de macrófagos, células endoteliais capilares e principalmente fibroblastos. As primeiras fibras de colágeno produzidas pelos fibroblastos surgem em quatro a cinco dias e o espaço da ferida é preenchido rapidamente por pequenos feixes orientados ao acaso, que aumentam gradativamente dando origem a uma estrutura densa e consistente, que une firmemente os tecidos lesados (MAJNO, 1992), de modo que, no décimo dia pós-lesão já se apresenta metade do número total de células. Dois ou três dias após o ferimento, continuando nas próximas duas a três semanas, diferencia-se no tecido de granulação, uma célula que possui características ultraestruturais dos fibroblastos e da célula muscular lisa, denominada miofibroblasto, dando-lhe capacidade contrátil, reduzindo a área cruenta da ferida facilitando a epitelização (WITTE; BARBUL, 1997). 
A pele possui o plexo subpapilar localizado abaixo das papilas dérmicas e 0 plexo cutâneo, que é mais profundo, e fica na junção entre a hipoderme e a derme. A derme papilar apresenta um suprimento sanguíneo maior do que a derme reticular, nessa camada, os vasos são numerosos apenas quando associados aos anexos cutâneos. As arteríolas do plexo subpapilar dirigem-se em direção à epiderme e originam capilares que adentram as papilas dérmicas sob a forma de alças (MONTAGNA, 1962).

A angiogênese é o processo pelo qual surgem novos vasos para refazer a circulação local, necessária para oxigenação e nutrição da ferida, diante da hipóxia e a diminuição do $\mathrm{pH}$ no centro da lesão. Esse evento tem como componente fundamental os macrófagos, que fazem uma interação com os tromboxanos e as prostaglandinas produzindo assim o fator angiogênico (quimiotático) que atrai as células meso e endoteliais (WITTE; BARBUL, 1997).

No presente estudo verificou-se através da MEV, principalmente nos animais do grupo GIII(14), uma neovascularização acentuada, bem como uma proliferação de tecido colágeno e predomínio e aumento da espessura da área tratada, corroborando com os dados da literatura acerca dos processos de reepitelização com relação à utilização da BML.

Finalizando, observou-se na presente pesquisa, que a LTE provocou uma interrupção do crescimento dos folículos pilosos, com atrofia folicular e alopecia. Interessante é que, apesar da LTE ter alterado o crescimento dos folículos pilosos, os animais do grupo GIII, tiveram discreta retomada do crescimento folicular. Isso pode ter sido uma resposta ao tratamento realizado com a BML, que provocou uma maturação mais rápida do tecido conjuntivo e assim, estimulando o crescimento folicular.

\subsubsection{Sistema colágeno}

A característica mecânica da pele promove uma única combinação de elasticidade e resistência, predominantemente devido à rede colágena da derme e, em menor grau, à elastina e substância da matriz extracelular (HOLBROOK et al., 1982; PEACOCK, 1984). Histologicamente, uma pele normal revela que os feixes de 
fibras colágenas apresentam-se completamente entrelaçados e randomicamente organizados (LINARES, 1996). Dentre os vários tipos de colágeno no corpo, o principal constituinte da derme é o colágeno tipo I (RICH; CRICK, 1955; ALBERTS et al., 2006).

Alterações na arquitetura colágena estão presentes em tecido cicatricial, como em pele humana carente da capacidade de regenerar após ferimentos. A reintegração tecidual gera um mecanismo reparador que, freqüentemente, resulta em uma forte cicatriz, que é menos flexível e menos resistente que a pele saudável. Histologicamente, estudos de tecido cicatricial maduro mostram feixes de fibras colágenas em orientação paralela à epiderme, diferentemente daqueles feixes colágenos randomicamente organizados encontrados em uma derme normal (LINARES, 1996).

A pele normal e uma cicatriz madura contêm colágeno dos tipos I e III, com predomínio do tipo I. Contrariamente, o tecido de granulação é amplamente composto por colágeno tipo III (GABBIANI et al., 1976). A estrutura do colágeno é uma parte integrante das pesquisas sobre a restauração de ferimentos, sendo avaliada sob luz polarizada, o que torna a estrutura do colágeno facilmente identificável (WOLMAN; KASTEN, 1986).

Em estudo com a técnica de picro-sirius sob luz polarizada, no efeito radioprotetor do selenito de sódio no processo de reparação tecidual em ratos, Tuji et al. (2005) verificaram após o décimo quarto dia, processos de remodelação das estruturas de epiderme e derme mostrando fibras de colágeno em fase de reorganização e aparente neoformação de vasos sangüíneos, características importantes para cicatrização de feridas. Outro estudo avaliando a morfologia e histoquímica da pele de ratas hipotireóideas castradas e não castradas, a técnica de coloração pelo picro-sirius e análise sob luz polarizada mostrou, claramente, as alterações do colágeno em razão da LTE. Houve uma diminuição, desarranjo e até mesmo o desaparecimento de determinados tipos de colágeno, o que comprova a inibição da síntese, maturação e renovação do mesmo devido às alterações hormonais provocados pela queimadura (FERREIRA et al., 2003b).

$\mathrm{Na}$ presente pesquisa observou-se que na região da derme papilar dos animais do grupo $\mathrm{Gl}$, as fibras colágenas seguem paralelas à superfície epitelial. Em todas as regiões da derme reticular foram verificadas fibras colágenas mais 
espessas (tipo I) orientadas em todos os ângulos, entrelaçadas em um arranjo tridimensional, conforme descrito por Wolman e Kasten (1986) e Linares (1996).

Os dados aqui apresentados demonstram que na derme dos animais do grupo GI, as fibras colágenas preenchem quase toda a matriz extracelular de forma bastante homogênea, cedendo espaço apenas para os folículos pilosos e glândulas sebáceas. Nos animais do grupo Gll, estas fibras estão estruturalmente alteradas, compactadas e mais delgadas, quando comparadas àquelas nos animais do grupo Gl. Os aspectos referentes ao tecido colágeno, principalmente em GIII(14), onde houve um espessamento da derme papilar e reticular superficial, se deve à neoformação colágena. Isso corrobora com as descrições relativas ao processo de reparação tecidual. No início o colágeno é imaturo, isto é, com grande quantidade de fibroblastos e fibras colágenas menos densas devido à grande quantidade de água que possuem. Com o passar do tempo o colágeno amadurece, tornando-se menos celular e com menor quantidade de água. A partir dessa fase, o tecido conjuntivo vai amadurecendo progressivamente, com maior deposição de colágeno maduro, o qual é responsável pelo espessamento das áreas lesadas no período de cicatrização (HALLOCK; RICE, 1993; HUGHES, 1998; NORONHA, et al., 2001b). No modelo experimental aqui avaliado, especificadamente, nos animais dos grupos Gll(14) e GIII(14), verificou-se um grande espessamento do tegumento porém, esse espessamento mostrou-se bem maior nos animais tratados com a BML, às custas da presença do tecido de granulação. Nos animais do grupo GIII(14), observou-se um aumento de fibras colágenas do tipo III, sugerindo maturação do tecido de granulação e intensa produção de tecido colágeno. Este fato corrobora com outros estudos avaliando os benefícios do tratamento com a BML em tecidos lesados. Contrariamente, nos animais do grupo GII(14), embora a pele tenha se espessado, na região correspondente ao tecido de granulação, as fibras colágenas estavam praticamente ausentes observadas na técnica de coloração pelo picro-sirius avaliados sob luz polarizada.

A área superficial de colágeno coagulado presente nas lesões é mais endurecida, de difícil fixação, processamento e corte, inviabilizando, por vezes, algum preparo histológico (ROSS et al., 1996; AUERSVAULD, 1999; FRANÇA, 1999; ROSS et al., 1999; NORONHA et al., 2001a,b,c). Este fato também foi observado na presente pesquisa durante a preparação do material. Quanto à superfície de colágeno endurecida e coagulada observou-se nas imagens da MEV, 
estas mesmas características. Em nosso estudo, observou-se ainda, uma homogeneização do colágeno da derme reticular superficial e perda da sua afinidade tintorial à hematoxilina e eosina, bem como em outros corantes. Nossos resultados, portanto, corroboram com a literatura revisada (ROSS et al., 1996; AUERSVAULD, 1999; FRANÇA, 1999; ROSS et al., 1999; NORONHA et al., 2001a,b,c).

O colágeno por ser o tipo mais abundante de proteína do organismo, representando $30 \%$ do seu peso seco, certamente sofre com lesões físicas provocadas pelo calor, desta forma, principalmente na derme dos animais queimados, estas fibras apresentaram-se com um aspecto fundido e compactado, provavelmente devido a desnaturação protéica que estas fibras sofreram devido a LTE, fato este, observado neste estudo quando analisamos as imagens oriundas da polarização do picro-sirius e da MEV e está de acordo com as observações feitas por Auersvauld (1999) e Tuji et al. (2005).

Os animais do grupo GIII, apresentaram padrão semelhante em relação ao surgimento da birrefringência dos tecidos, indicando que o tecido nesses animais atingiu maturação e orientação macromolecular precocemente em relação aos animais do grupo GII, o que permite inferir um atraso na reparação tecidual destes últimos. Este fato também foi relatado por Tuji et al. (2005) em estudos com radioproteção.

\subsubsection{Sistema de fibras elásticas}

As fibras elásticas na derme, responsáveis pela elasticidade da pele, são espessas e arranjadas horizontalmente, formando bandas achatadas entrelaçadas com fibras colágenas. Na derme papilar são observadas fibras elaunínicas, fibras mais delgadas e de arranjo perpendicular que se fundem com as fibras oxitalânicas de aspecto exclusivamente microfibrilar, cuja função é dar suporte e proteção à junção dermo-epidérmica (MONTAGNA, 1962, KIELTY et al., 2002), porém estas não foram contempladas neste estudo. Os ratos apresentam entre os folículos pilosos, fibras elásticas espessas (maduras) conectando um folículo piloso ao outro, além disso, observou-se uma intensa rede elástica na cobertura destes folículos 
pilosos o que corrobora com a literatura avaliada, as quais dão flexibilidade aos pêlos (MONTAGNA, 1962).

Na presente pesquisa observou-se nos animais do grupo Gll(4), que as fibras elásticas adensaram-se no terço médio da derme, a ponto de poder considerar a formação de uma verdadeira camada constituída por essas fibras; adensamento este, provavelmente determinado pela elevada temperatura. Isto pode ser explicado pelas descrições de Lin et al. (2006) que demonstraram que o processo de desnaturação protéica da pele inicia-se a $60^{\circ} \mathrm{C}$, com desnaturação das fibras colágenas e a $65^{\circ} \mathrm{C}$, com desnaturação das fibras elásticas. Com o aumento da temperatura, as estruturas de tanto as fibras colágenas e as fibras elásticas se deterioram. Todavia, o importante a ser ressaltado é que, com a utilização da BML, ficou evidente a regeneração do tecido colágeno e do sistema de fibras elásticas, que se mostraram mais celular no quarto dia e, quase completamente regenerado no décimo quarto dia, em muito se assemelhando aos animais do grupo Gl. 


\section{CONCLUSÕES}

De acordo com os resultados apresentados, somados à metodologia utilizada para o alcance dos mesmos, pode-se inferir as primeiras considerações acerca do tratamento com a utilização da BML sob o leito de ferimentos à base de lesões térmicas corporais por escaldamento.

Assim sendo, o modelo animal é apenas adequado para estudos preliminares, porém não totalmente comparáveis à pele humana.

$>\mathrm{O}$ tratamento da área lesada com a BML foi tolerado pelos animais durante todo o período experimental sem observação de óbito entre os mesmos.

$>$ O modelo experimental utilizado para esta pesquisa foi adequado para promover uma lesão de segundo grau, lesão esta suficiente para sugerir as primeiras considerações em relação aos benefícios do tratamento com a BML.

A utilização da BML no tratamento da LTE ofereceu proteção ao leito ferido com baixo custo, de fácil armazenamento, durável, flexível, resistente ao estiramento, boa aderência ao leito, além de poder ser utilizada por tempo prolongado, de adaptar-se aos contornos da ferida e de propiciar a formação de um tecido de granulação adequado, com presença considerável de fibras colágenas.

Os exames histológicos, histomorfométricos e estereológico deste estudo quanto à espessura do processo inflamatório (tecido de granulação) mostraram superioridade dos animais que utilizaram a BML.

A maior espessura do tecido de granulação nos animais do grupo GIII é positiva, por conter maior número de neovasos e fibras colágenas, o que proporcionou um tecido de granulação mais maduro e um reparo tecidual de melhor qualidade. 
> A BML promoveu boa reconstituição do tegumento dos animais do grupo GIII, porém o tempo de 14 dias não foi suficiente para total reepitelização.

> Comprovou-se a atividade neoangiogênese da BML, corroborando com outros estudos.

> Quanto à tipificação do colágeno, observou-se colágeno tipo I e tipo III no tegumento dos animais, porém observou-se predominância do colágeno tipo III nos animais do grupo GI, do colágeno tipo I nos animais do grupo Gll e nos animais do grupo GIII, ocorreu um predomínio das fibras do tipo I mais semelhante aos animais do grupo $\mathrm{GI}$.

$>$ Relativamente ao sistema colágeno, a BML foi eficiente quanto à neoformação de novas fibras.

Em relação ao sistema elástico, a BML foi favorável. Nos animais do grupo GIII, a distribuição assemelhou-se ao encontrado nos animais do grupo GI,

Desta forma, segundo esta pesquisa, a Biomembrana de Látex Natural (BML) é um promissor recurso terapêutico para cicatrização da pele, particularmente nos casos em que a revascularização tecidual, neoformação colágena e preservação do sistema elástico seja importante, como é o caso de lesões térmicas corporais por escaldamento. 


\section{REFERÊNCIAS}

ABLA, L. E. F.; ISHIZUKA, M. M. A. Fisiopatologia das Feridas. In: Manual de cirurgia plástica. São Paulo: Atheneu, 1995. p. 5-11.

AKSOY, M. H.; VARGEL, I.; CANTER, I. H. ERK, Y.; SARGON, M. PINAR, A., GÜLER TEZEL, G. A new experimental hypertrophic scar model in guinea pigs. Aesthetic Plastic Surgery, v. 26, p. 388-396, 2002.

ALBERTS, B.; BRAY, D.; JOHNSON, A.; LEWIS, J.; RAFF, M.; ROBERTS, K.; WALTER, P. Fundamentos da biologia celular: uma introdução à biologia molecular da célula. 2. ed. Porto Alegre: Artmed, 2006. 866 p.

ALBERTS, B.; JOHNSON, A.; WALTER, P. Biologia molecular da célula. 3. ed. Porto Alegre: Artes Médicas, 1997. 1584p

ANDRADE, T. A. M. Atividade da biomembrana de látex natural da seringueira Hevea brasiliensis na neoformacao tecidual em camundongos. 2007.

Dissertação (Mestrado em Clínica Médica) - Faculdade de Medicina de Ribeirão Preto, Ribeirão Preto, 2007.

ANDRADE, M. N. B.; SEWARD, R.; MELO, J. R. C. Curativos. Revista da Associação Médica de Minas Gerais, v. 2, n. 4, p. 228-236, 1992.

ANGEL, M. E; NARAYANA, K.; SWARTZ, W. M. The etiologic role of free radicals in hematoma-induced flap, necrosis, Plastic and Reconstructive Surgery, v. 77, p. 795, 1986.

ARNOLD, J. R. H. L.; ODOM, R. B.; JAMES, W. D. Doenças da Pele de Andrews: dermatologia clínica. 8. ed. São Paulo: Manole,1994.1124 p.

AUERSVAULD, A. Estudo experimental em ratos da ablação da pele em laser $\mathbf{C O}_{2}$ ultrapulsado. 1999. 103 p. Dissertação (Mestrado em Princípios da Cirurgia) -

Conforme as Diretrizes para apresentação de dissertações e teses na Faculdade de Medicina Veterinária e Zootecnia da Universidade de São Paulo. 4. ed. rev. atual. ampl. São Paulo: FMVZUSP, 2003. 84 P. 
Faculdade Evangélica de Medicina do Paraná. Hospital Universitário Evangélico de Curitiba, Curitiba, 1999.

AZÔR, A. F. Tratamento de peritoniostomia com biomembrana de látex natural - Estudo experimental em coelhos. 2004. 96 p. Tese (Doutorado em Medicina) Faculdade de Medicina de Ribeirão Preto. Universidade de São Paulo, Ribeirão Preto, 2004.

BADDELEY, A. J.; GUNDERSEN, H. J. G.; CRUZ-ORIVE, L. M. Estimation of surface área from vertical sections. Journal of Microscopy, v.142, n. 3, p. 259-276, 1986.

BAL, H. S. Pele. In: SWENSON, M. J.; REECE, W. O. Dukes fisiologia dos animais domésticos. 11. ed. Rio de Janeiro: Guanabara Koogan, 1996. p. 560-569.

BALAAS, A.; HOLMGREN, H. J. The basic dye uptae and the presence of growth inhibiting substance in the healing tissue of skin wounds, Experimental cell Research, v. 1, p. 206, 1950.

BARACOS, V.; RODENMANN, H. P.; DINARELLO, C. A.; GOLDBERG, A. L. Stimulation of mucle protein degradation and prostaglandin $\mathrm{E} 2$ release by leukocytic pyrogen (interleukin-1). The New England Journal of Medicine, v. 308, p. 553-557, 1983.

BEVILACQUA, L. R.; WAITZBERG, D. L.; SOARES, D. C.; BEVILACQUA, G. A. Efeito imunomodulador de hormônios tímicos sobre o trauma térmico experimental. Acta Cirúrgica Brasileira., v. 12, n. 2, p. 104-110, 1997.

BLANES, L. Perfil do portador de úlcera por pressão internado no Hospital São Paulo. 2002. 74 p. Dissertação (Mestrado em Enfermagem). Faculdade de Enfermagem, Universidade Federal de São Paulo, São Paulo, 2002.

BORGES, E. L. Fatores intervenientes no processo de cicatrização. In: Feridas: como tratar. Belo Horizonte: Coopmed, 2001. p. 51-59.

BORGES, A. F.; ALEXANDER, J. E. Relaxed skin tension lines, Z-plasties for scars, and fusiform excision of lesions, British Journal of Plastic Surgery, v. 125, p. 242, 1962. 
BORGES, E. L.; SAAR, S. R. C.; LIMA, V. L. A. N.; GOMES, F. S. L.; MAGALHÃES, M. B. B. Feridas: como tratar. Belo Horizonte: Coopmed, 2001, p. 97-120.

BRANS, T. A.; DUTRIEUX, R. P.; HOEKSTRA, M. J.; KREIS, R. W.; DUPONT, J. S. Histopathological evaluation of scalds and contact burns in the pig model. Burns, v. 20, n. 1, p. 48-51, 1994.

BRYANT, R. A. Acute and chronic wounds: nursing managment. 2. ed. St Louis: Mosby; 1992. p.105-163.

CESARETTI, I. U. R. Processo fisiológico de cicatrização da ferida. Pelle Sana, v. 2, p. 10-12, 1998.

CLARK, R. A. F.; WINN, H. J.; DVORAK, H. F. Fibronectin beneath reepithelializing epidermis in vivo. Sources and significance, The Journal of Investigative Dermatology, v. 80, p. 0263, 1983.

CLEARY, E. G.; GIBSON, M. A. Elastin-associated microfibrils and microfibrilar proteins. International Review of Connective Tissue Research, v. 10, p. 97, 1983.

ClOWERS, G. H. A.; GEORGE, B. A.; VILLEE, C. A.; SAVARIS, C. A. Muscle proteolysis induced by circulating peptide in pathients with sepsis and trauma. The New England Journal of Medicine, v. 308, p. 545-552, 1983.

COHN, Z. A. The activation of mononuclear phagocytes: Fact, fancy and future. Journal of Immunology, v. 121, p. 813-816, 1978.

COSTA, D. M.; ABRANTES, M. M.; LAMOUNIER, J. A.; LEMOS, A. T. Estudo descritivo de queimaduras em crianças e adolescentes. Journal of Pediatric, v. 75, n. 3, p. 181-186, 1999.

COSTA, D. M.; LEMOS, A. T.; LAMOUNIER, J. A.; CRUVINEL, M. G.; PEREIRA, M. $V$. Estudo retrospectivo de queimaduras na infância e na adolescência. Revista da Associação Médica de Minas Gerais, v. 4, n. 2, p. 102-104, 1994.

COTRAN, R. S. Endothelial cells. In: Philadelphia: W.B.Saunders Co., 1993. p. 327-336.

Textbook of reumathology, 4. ed. 
COTRAN, R. S.; KUMAR, R.; COLLINS, T. Patologia estrutural e funcional. 6. ed. Rio de Janeiro: Guanabara Koogan S. A., 2000, 1251 p.

CUTTLE, L.; KEMPF, M.; PHILLIPS, G. E.; MILL, J.; HAYES, M. T.; FRASER, J. F.; WANG, X. Q.; KIMBLE, R. M. A porcine deep dermal partial thickness burn model with hypertrophic scarring, Burns, v. 32, p. 806-820, 2006.

DE LOS SANTOS GONZÁLEZ, C. E. Guía básica para el tratamiento del paciente quemado. 2. ed. España: Ed. Libros electrónicos.net., 2004. Cap. 4. Electrónica. Disponível em: <http://www.indexer.net/quemados/clasificaciones.htm>. Acesso em: 28 Jul 2008.

DEALEY, C. Cuidando de feridas: um guia para enfermeiras. São Paulo: Atheneu, 1996. p.1-21.

DEITCH, E. A.; WHEELAHAN, T. M.; ROSE, M. P.; CLOTHIER, J.; COTTER, J. Hypertrophic burn scars: analysis of variables. The Journal of Trauma, v. 23, n. 10, p. $895-898,1983$.

DELEGUIDE, N.; LIBANORE, D. Z.; SOUSA, H. G.; TRONQUINI, P .O. O uso da biomembrana natural de látex da seringueira Hevea brasiliensis, na cicatrização de ulceras diabéticas. Um estudo de caso. CONGRESSO DE INICIAÇÃO CIENTÍFICA, 16., 2008, São Carlos. Anais... São Carlos, v. 4, p. 604, 2008.

DELESSE, M. A. Procédé mécanique pour déterminer la composition des roches. Comptes Rendus de l'Académie des Sciences, Paris v. 25, p. 544-545, 1847.

DIEGELMANN, R. F.; COHEN, I. K.; McCOY, B. J. Growyh kinetics and collagen synthesis of normal skin, normal scar and keloid fibroblasts in vitro, Journal of Cellular Physiology, v. 98, p. 341, 1979.

DOUGHTY, D. B. Principles of wound healing and wound managemant. In: Acute and chronic wounds: nursing management. St Louis: Mosby; 1992. Cap 2, p. 31-68.

DOUGLAS, W. R. Of pigs and men and research. Space Life Sciences, v. 3, p. 226234, 1972. 
DOWNEY, R. S.; MONAFO, W. W.; KARL, I. E.; MATTHEWS, D. E.; BIER, D. M. Protein dynamics in skeletal muscle after trauma: local and sistemics effects.

Surgery, v. 99, n. 3, p. 265-273, 1986.

DYCE, K. M.; SACK, W. O.; WENSING, C. J. G. Tratado de anatomia veterinária. 3. ed. Rio de Janeiro: Elsevier, 2004. 813 p

EURELL, J. A.; FRAPPIER, B. L. Integument. In: Dellmann's extbook of veterinary histology. 6. ed. Philadelphia: Blackwell Publishing, 2006. p. 320-246.

FAY, A. M.; PIEROTH, L.; RUBIN, P. A. An animal model of lower eyelid spacer grafting with acellular dermis. Ophthalmic Plastic and Reconstructive Surgery, v. 7, p. 270-275, 2001.

FEARSON, D. T.; AUSTEN, K. R. Activation of the alternative complement pathway by $\mathrm{E}$. coli: resistance of bound c3b to inactivation by c3b INA and $\mathrm{BIH}$, Journal of Immunology, v. 120, p. 1772, 1977.

FERGUSON, M. K. The effect of antineoplastic agents on wound medications affecting wound healing, Surgery, Gynecology \& Obstetrics, v. 154, p. 421, 1982.

FERREIRA, E.; LUCAS, R.; ROSSI, L. A.; ANDRADE, D. Curativo do paciente queimado: uma revisão de literatura. Revista da Escola de Enfermagem da USP., v. 37 , n. 1, p. 44-51, 2003 a.

FERREIRA, E.; SERAKIDES, R.; NUNES, V. A.; GOMES, M. G.; SILVA, C. M.; OCARINO, N. M.; RIBEIRO, A. F. C. Morfologia e histoquímica da pele de ratas hipotireóideas castradas e não castradas. Arquivo Brasileiro de Medicina Veterinária e Zootecnia, v. 55, n. 1, p. 51-60, 2003b.

FINE, N.; MUSTOE, T. A. Wound healing. In: Scientific principles and practice. 3. ed. Philadelphia: Lippincott Williams e Wilkins; 2001. p. 69-85.

FLECKNELL, P. Pain - assessment, alleviation and avoidance in laboratory animals. ANZCCART News, v. 12, n. 4, p. 1-8, 1999.

FORREST, L. Current concepts in soft connective tissue wound. The British Journal of Surgery, v. 70, p. 133-140, 1983. 
FRADE, M. A. C.; VALVERDE, R. V.; ASSIS, R. V. C.; COUTINHO-NETTO, J.; FOSS, N. T. Chronic phlebopathic cutaneous ulcer: a therapeutic proposal. International Journal of Dermatology, v. 40, p. 237-240, 2001.

FRANÇA, A. L. F. Estudo histopatológico das lesões causadas por duas e quatro passadas de laser de Erbium: YAG com 0\% de sobreposição de spots, em dorso de ratos. 1999. 134 p. Dissertação (Mestrado em Clínica Cirúrgica) Setor de Ciências da Saúde, Universidade Federal do Paraná, Curitiba. 1999.

FREITAS, M. A. S. Avaliação da prótese de látex natural como remendo em arterioplastias femorais. Estudo experimental em cães. 2001.90 p. (Doutorado em Medicina) - Programa de Pós-graduação em Clínica Cirúrgica, Faculdade de Medicina, Universidade de São Paulo, Ribeirão Preto, 2001.

GABBIANI, G.; LELOUS, M.; BAILEY, A. J. Collagen and myofibroblasts of granulation tissue. A chemical, ultraestructural and immunologic study, Cell Pathology, v. 21, p. 133, 1976.

GAWLIK, Z. Morphological and morphochemical properties ofthe elastic system in the motor organ of man. Folia Histochemica et Cytochemica, v. 3, p. 233-251, 1965.

GAY, S. M.; MILLER, E. J. Collagen in the physiology and pathology of connective tissue. Stuttgart: Gustav Fischer, 1978.

GODOY, L. Efeitos do medicamento Método Canova ${ }^{\circledR}$ sobre a funcionalidade de macrófagos. 2002. 70 p. Dissertação (Mestrado em Biologia Celular)Universidade Federal do Paraná, Curitiba, 2002.

GOMES, D. R.; MACIEIRA, J. R. G.; SERRA, M. C.; SCHECHTMANN, M. A. Moderno tratamiento tópico de las quemaduras y utilización de antibioticoterapía sistémica. Revista Argentina Quemaduras, v.15, n. 2, p. 9-20, 2000.

GONÇALVES, E. L.; BEVILACQUA, G. A.; WAITZBERG, D. L.; BEVILACQUA, L. R. Consumo preferencial de substrato no trauma por queimadura. Estudo experimental. Acta Cirúrgica Brasileira, v. 6, n. 4, p. 152-158, 1991.

GONÇALVES, M. T. F. A úlcera por pressão e o idoso. Nursing, v. 9, n. 106, p. 13$17,1996$. 
GRAF, R. Estudo da contração cutânea após o uso do laser Erbium: YAG em ratos. 2000. 98 p. Dissertação (Mestrado em Princípios da Cirurgia) - Faculdade Evangélica de Medicina do Paraná, Hospital Universitário Evangélico de Curitiba, Curitiba, 2000.

GUILLEN, D. G.; ALBARRACÍM, A.; ARQUIROLA, E. Historia del medicamento., Madrid: Harcourt Brace España, SA 1987. fasc. 2, 171-195 p.

GUNDERSEN, H. J. G. Stereology of arbitrary particles. A review of unbiased number and size estimators and the presentation of some new ones, in the memory of William R. Thompson. Journal of Microscopy, v. 143, p. 3-45, 1986.

GUNDERSEN, H. J. G.; JENSEN, E. B. The efficiency of systematic sampling in stereology and its prediction. Journal of Microscopy, v.147, p. 229-263, 1987.

GUNDERSEN, H. J. G.; JENSEN, E. B.; KIEU, K.; NIELSEN, J. The efficiency of systematic sampling in stereology-reconsidered. Journal of Microscopy, v. 3, n. 193, p.199-211, 1999.

HALLOCK, G. G.; RICE, D. C. Comparison of the contact neodymium:YAG and carbon dioxide lasers for skin deepithelialization. Plastic and Reconstructive Surgery., v. 91, n. 6, p. 1134-1139, 1993.

HEATHCOTE, J. G.; GRANT, M. E. The molecular organization of basement membranes, International Review of Connective Tissue Research, v. 9, p. 191, 1981.

HERBERT, I. J.; TURINSKY, J. Effects of thermal injury on glucocorticoid and androgen binding in skeletal muscles with differents fiber populations. The Journal of Trauma, v. 22, n. 10, p. 845-852, 1982.

HETTIARATCHY, S.; DZIEWULSKI, P. ABC of burns. Introduction. BMJ, v. 328, n. 7452, p. 1366-1368, 2004.

HINRICHSEN, N.; BIRK-SORENSEN, L.; GOTTRUP, F.; HJORTDAL, V. Wound contraction in an experimental porcine model. Scandinavian Journal of Plastic and Reconstructive Surgery and Hand Surgery, v. 32, p. 243-248, 1998. 
HOLBROOK, K. A.; BYERS, P. H.; PINNELL, S. R. The structure and function of dermal connective tissue in normal individuals and patients with inherited connective tissue disorders. Scanning Electron Microscopy, Pt. 4, p. 1731-1744, 1982.

HOM, D. B. Growth factors in wound healing. Otolaryngologic Clinics of North America, v. 28, p. 935, 1995.

HOM, D.B. Grow factors. Biological Basis of Facial Plastic Surgery. New York, Thieme Medical Publishers, 1993.

HOWARD, C. V.; REED, M. G. Three-dimensional measurement in microscopy. In:_Unbiased Stereology. Oxford: Bios Scientific Publishers, 2005. 246 p.

HUGHES, P. S. H. Skin contraction following Erbium: YAG laser resurfacing.

Dermatologic Surgery, v. 24, p. 109-111, 1998.

HUNT, J. L.; SATA, R. M. Early excision of full thickness hand and digit burns: factors affecting morbidity. The Journal of Trauma, v. 22, p. 414-419, 1982.

IBEBUNJO, C.; MARTYN, J. A. J. Disparate dysfunction of skeletal muscles located near and distant from burn site in the rat. Muscle \& Nerve, v. 24, n.10, p.1283-1294, 2001.

IOACHIM, E.; CHARCHANTI, A.; BRIASOULIS, E.; KARAVASILIS, V.; TSANOU, H.; ARVANITIS, D. L.; AGNANTIS, N. J.; PAVLIDIS, N. Immunohistochemical expression of extracellular matrix components tenascin, fibronectin, collagen type IV and laminin in breast cancer: their prognostic value and role in tumour invasion and progression. European Journal of Cancer, v. 38, p. 2362-2370, 2002.

IREI, M.; ABSTON, S.; BONDS, E.; RUTAN, T.; DESAI, M.; HEMDON, D. N. The optimal time for excision of scald burns in toddlers. The Journal of Burn Care \& rehabilitation v. 7, p. 508-510, 1986.

JANZEKOVIC, Z. A new concept in die early excision and inmediate grafting of burns. The Journal of Trauma, v. 10, n. p. 1103-1108, 1970

JUNQUEIRA, L. C. U.; BIGNOLAS, G.; BRENTANI, R. R. Picrosirius staining plus polarization microscopy, a specific method for collagen detection in tissue sections. The Histochemical Journal., v.11, p. 447-455, 1979. 
KAO, C. C.; GARNER, W. L. Acute burns. Plastic and Reconstructive Surgery, v. 105, n. 7, p. 2482-2492, 2000.

KIELTY, C. M. SHERRATT, M. J. SHUTTLEWORTH, C. A. Elastic fibers. Journal of Cell Science, v. 115, p. 2817-2828, 2002.

KISTLER, D.; HAFEMANN, B.; SCHMIDT, K. A model to reproduce predictable fullthickness burns in an experimental animal. Burns, Including Thermal Injury, v. 14, p. 297-302, 1988.

$\mathrm{KOHN}, \mathrm{S}$. Structural basis of hyperpermeability of tumor blood vessels.

Laboratory Investigation, v. 67, p. 596, 1992.

KOPP, J.; WANG, G. Y.; HORCH, R. E.; PALLUA, N.; GE, S. D. Ancient Traditional Chinese medicine in burn treatment: a historical review. Burns, v. 29, n. 5, p. 473478, 2003.

KRSTIC, R. V. Illustrated encyclopedia of human histology. New York: Springer Verlag, 1984.

LACHAT, J. J.; MRUÉ, F.; THOMAZINI, J. A.; ZBOROWSKI, A. C.; CENEVIVA, R.; COUTINHO-NETTO, J. Morphological and biochemical studies of the biocompability of a membrane manufactured from the latex of Hevea brasiliensis. Microscopica Acta, v. 6, p. 758-759, 1997. Suplemento B

LARK, M. W.; LATERRA, J.; CULP, I. A. Close and focal contact adhesions of fibroblasts to a fibronectin-containing matrix, Federation Proceedings, v. 44, p. 394, 1985.

LEE, M. A; PALACE, J.; STABLER, G.; FORD, J.; GEARING, A.; MILLER, K. Serum gelatinase $B$, TIMP-1 and TIMP-2 levels in multiple sclerosis. A Longitudinal clinical and MRI study. Brain, v. 122, p. 191-197, 1999.

LIN, M. G.; YANG, T. L.; CHIANG, C. T.; KAO, H. C.; LEE, J. N.; LO, W.; JEE, S. H.; CHEN, Y. F.; DONG, C. Y.; LIN, S. J. Evaluation of dermal thermal damage by multiphoton autofluoresecence and second-harmonic-generation microscopy. Journal of Biomedical Optics, v. 11, n. 6, p. 064006, 2006. 
LOCHTER, A.; BISSEL, M. Involvement of extracellular matrix constituents in breast cancer. Cancer Biology, v. 6, p. 165-173, 1995.

LODOVICI, O. Fatores locais que interferem sobre a cicatrização. In:

Clínica Cirúrgica. São Paulo: Sarvier, 1994. 139-144 p.

LOPES, L. G. F.; MENDES JUNIOR, E. C. S.; SANCHES, J. A. VIDAL, M. A.; BUSSOLARO, R. A.; ROCHA, A. B. Epidemiologia do grande queimado de 2001 a 2003 atendidos na U.T.Q. da Faculdade de Medicina de Catanduva-SP. Review Klinikos, v.19, p. 83-88, 2004.

MAJNO, G. The capillary then and now: An overview of capillary pathology. Modern Pathology, v. 5, p. 9, 1992.

MANZI, F. R.; BÓSCOLO, F. N.; ALMEIDA, S. M.; TUJI, F. M. Estudo morfológico do efeito redioprotetor da vitamina $E$ (dl-alfa-tocoferil) na reparação tecidual em ratos.

Radiologia Brasileira, v. 36, p. 367-371, 2003.

MCGRATH, I. A.; EADY, R. A. J.; POPE, F. M. Anatomy and organization of human skin. In: Textbook of Dermatology, 5. ed. New York: Blackwell Scientific, 1992. cap. 3, p.1-15.

MENDES JUNIOR, E. C. S.; VITERBO, F.; ROSA, C. S. Análise histológica e morfométrica da área cruenta tratada com membrana de silicone: estudo em ratos.

Revista da Associação Médica Brasileira, v. 53, n. 5, p. 395-400, 2007.

MENTE, E. D. Desenvolvimento do protótipo de dispositivo para macroencapsulamento de ilhotas pancreáticas a partir de biomembrana natural de látex. 2002. Tese (Doutorado). Universidade de São Paulo; Ribeirão Preto, 2002.

MERZ, J.; SCHRAND, C.; MERTENS, D.; FOOTE, C.; PORTER, K.; REGNOLD, L. Wound care of the pediatric burn patient. AACN clinical issues, v. 14, n. 4, p. 429441, 2003.

MEYER, W.; SCHWARZ, R.; NEURAND, K. The skin of domestic mammals as a model for the human skin, with special reference to the domestic pig. Current Problems in Dermatology, v. 7, p. 39-52, 1978.

MINITAB. Minitab reference manual. Florence: Wadsworth, v. 15, 2007. 
MINOR, R. R. Collagen metabolism. The American Journal of Pathology, v. 98, p. 255, 1988.

MONTAGNA, W. The structure and function of skin. 2. ed. New York: Academic Press, 1962. $435 \mathrm{p}$.

MONTAGNA, W.; YUN, J. S. The skin of the domestic pig. The Journal of Investigative Dermatology, v. 42, p. 11-21, 1964.

MONTANDON, D.; D'ANDIRAM, G.; GABBIANI, G. The mechanism of wound contraction and epithelialization: clinical and experimental studies. Clinics in Plastic Surgery, v. 14, p. 325-346, 1977.

MORITZ, A. R.; HENRIQUES, F. C. Studies of thermal injury 2: the relative importance of time and surface temperature in the causation of cutaneous burns. The American Journal of Pathology, p. 692-720, 1947.

MRUÉ, F. Neoformação tecidual induzida por biomembrana de látex natural com polilisina. Aplicabilidade em neoformação esofágica e da parede abdominal. Estudo experimental em cães. 2000. 112 p. Tese (Doutorado]. Universidade de São Paulo; Ribeirão Preto, 2000.

MRUÉ, F. Substituição do esôfago cervical por prótese biossintética de látex. Estudo experimental em cães. 1996. Dissertação (Mestrado). Universidade de São Paulo; Ribeirão Preto, 1996.

MRUÉ, F.; COUTINHO-NETTO, J.; CENEVIVA, R.; LACHAT, J. J.; THOMAZINI, J. A.; TAMBELINI, H. Evaluation of the biocompatibility of a new biomembrane. Journal of Materials Research., v. 7, n. 2, p. 277-283, 2004.

MUHART, M.; MCFALLS, S.; KIRSNER, R. S.; ELGART, G. W.; KERDEL, F.; SABOLINSKI, M. L. Behavior of tissue-engineered skin: a comparison of a living skin equivalent, autograft, and occlusive dressing in human donor sites. Archives of Dermatology, v. 135, p. 913-918, 1999.

NANNEY, L.; WENCZAK, B.; LYNCH, J. Progressive burn injury documented with vimentin immunostaining. The Journal of Burn Care \& Rehabilitation, v. 17, p. 191-198, 1996. 
NEWMAN, J. J.; STROME, D. R.; GOODWIN, C. W.; MASON Jr., A. D., PRUITT Jr., B. A. Altered muscle metabolism in rats after thermal injury. Metabolism, v. 31, n.12, p.1229-1233, 1982.

NORONHA, L.; AUERVAULD, A.; MARTINS, V. D. M.; BERNARDES, A.; GRAF, R. Estudo comparativo das alterações histológicas imediatas causadas pelo uso de lasers $\mathrm{CO}_{2}$ e de erbium na pele de ratos wistar. Jornal Brasileiro de Patologia, v. 37 , p. 273-278, 2001b.

NORONHA, L.; CHIN, E. W. K.; MENINI, C. M.; KNOPLHOLZ, J.; RAMPAZZO, J. C. R.; GRAF, R. Histopathologic and morphometric evaluation of the skin abnormalities induced by Erbium:Yag carbon dioxide lasers in 10 patients. Plastic and Reconstructive Surgery, v. 108, p. 1380-1388, 2001c.

NORONHA, L.; GRAF, R.; KANNENBERG, C.; BELLINI, P. A.; PELLEGRINELLO, S.; VROBLESWKI, T. V. Alterações histopatológicas causadas pela aplicação de laser $\mathrm{CO}_{2}$ em pele humana para fins de rejuvenescimento. Arquivos de Medicina, $\mathrm{v}$. 4, p. 179-183, 2001a.

OLIVEIRA, C. C.; OLIVEIRA, S. M.; GODOY, L. M. F.; GABARDO, J.; BUCHI, D. F. Canova, a brazilian medical formulation, alters oxidative metabolism of mice macrophages. The Journal of infection, v. 52, n. 6, p. 420-32. 2005.

OLIVEIRA, F. Características histoquimicas das fibras musculares do $\mathrm{m}$. gastrocnêmio de ratos Wistar desnutridos submetidos à lesão térmica por escaldamento. 2006. 140 f.Tese (Doutorado) -Instituto de Ciências Biomédicas, Universidade de São Paulo, São Paulo, 2006.

OLIVEIRA, J. A. A.; HIPÓLITO, M. A.; COUTINHO-NETTO, J. La regeneration du tympan avec l'utilization de matériel biosynthétique nouveau. In: Congres Français d'Otorhinolaringologie et de chirurgie de la face et du cou. 1999, Paris. Annais..., Paris, 1999. 273 p.

OLIVEIRA, J. A. A.; HIPÓLITO, M. A.; COUTINHO-NETTO, J.; MRUÉ, F. Miringoplastia com a utilização de um novo material biossintético. Revista Brasileira de Otorrinolaringologia, v. 69, p. 649-655, 2003.

OLIVEIRA, K. C.; PENHA, C. M.; MACEDO, J. M. Perfil epidemiológico de crianças vítimas de queimaduras. Arquivos de Medicina do ABC, v. 32, p. S55-S58, 2007. Suplemento 2. 
PAPP, A.; KIRALY, K.; HÄRMÄ, M.; LAHTINEN, T.; UUSARO, A.; ALHAVA, E. The progression of burn depth in experimental burns: a histological and methodological study. Burns, v. 30, p. 684-690, 2004.

PARTRIDGE, S. M.; ELSDEN, D. F.; THOMAS, J. Constitution of the cross-linkages in elastin. Nature, v. 197, n. 4874, p. 1297-1298, 1963.

PAULO, N. M.; JÚNIOR, J. T. S.; FLEURY, L.F. F.; SANTANA, F. J. F.; OLIVEIRA, L.F.; LIMA, F. G.; BORGES, A. C.; THELES, T. C. Látex da seringueira (Hevea brasiliensis) sem polilisina e tela de marlex na reconstrução da parede abdominal de ratos In: Congresso de Cirurgia da Zona da Mata Mineira, 1., 2004, Juiz de Fora.

Resumos... 2004. Não paginado.

PAULO, N. M.; SILVA, M. A. M.; CONCEIÇÃO, M. Biomembrane of natural látex (Hevea brasiliensis) with polylysine $0,1 \%$ for the perineal Hernirrhaphy in a dog. Acta Scientiae Veterinariae, v. 33, n. 1, p. 79-82, 2005.

PEACOCK, E. E. Structure, synthesis, and interaction of fibrous protein and matrix. In: . Peacock EE, 3. ed, Philadelphia: WB Saunders, 1984. p. 56-101.

PICCOLO, N. S. Brazil: Ideas from the past, trends of the present, and hopes form the future. Journal of Burn Care \& Rehabilitation, v. 23, n. 6, p. 386-400, 2002.

PINHO, E. C. C. M.; SOUSA, S. J. F.; SCHAUD, F.; LACHAT, J. J.; COUTINHONETO, J. Experimental use of látex biomembrane in conjunctival reconstruction Arquivos Brasileiros de Oftalmologia, v. 67, p. 27-32, 2004.

PROPHET, E. B.; MILLS, B.; ARRINGTON, J. B.; SOBIN, L. H. Afip laboratory methods in histotechnology. Washington, American Registry of Pathology, 1992, $278 \mathrm{p}$.

RABELO, R. E.; PAULO, N. M.; SILVA, L. A. F.; LIMA, C. R.; VIU, M. A. O.; FERNANDES, J. J. R.; ROMANI, A. F.; DAMASCENO, A. D.; ALVES, C. B.; SILVA, M. A. M. Emprego da biomembrana de látex natural com polilisina a $0,1 \%$ na hernioplastias umbilical recidivante em bovinos leiteiros. Brazilian Journal of Veterinary Research and Animal Science, v. 41, p. 233-234, 2004.

RICH, A.; CRICK, F. H. The structure of collagen. Nature, v. 175, n. 4489, p. 915-916, 1955. 
ROCHKIND, S.; ROUSSO, M.; NISSAN, M. Systemic effects of low-power laser irradiation on the peripheral and central nerouvs system, cutaneous wounds, and burns. Lasers in Surgery and Medicine, v.9, p. 174-178, 1989.

RODRIGUES, C. J.; SACHETTI, J. C. L.; RODRIGUES JUNIOR, A. J. Age related changes in the elastic fiber network of human splenic capsule.

Lynmphology v. 32, n. 2, p.64-69, 1999.

RODRIGUES JUNIOR, A. J.; TOLOSA, E. M. C.; CARVALHO, C. A. F. Electron microscopic study on the elastic and elastic related fibers in the human fascia transversalis at different ages. Gegenbaurs

Morphologisches Jahrbuch., v. 136, p. 645-652, 1990

ROMEIS, B. Mikroskopische technik. München, Wien: R. Ouldenbourg Verlag. 1968.

ROSEMBLOOM, J.; ABRAMS, W. R.; MECHAM, R. Extracellular matrix 4: the elastic fiber. The FASEB Journal v. 7, p. 1208-1218, 1993.

ROSIWAL, A. Ueber geometrische Gesteinsanalysen. Verh. K. Geol. Reichert, Wien, v. 13, p.143-175, 1898.

ROSS, E. V.; DOMANKEVITZ, Y.; SKROBAL, M.; ANDERSON, R. R. Effects of CO2 laser pulse duration in ablation and residual thermal damage: implications for skin resurfacing. Lasers in Surgery and Medicine, v. 19, p.123-129, 1996.

ROSS, E. V.; YASHAR, S. S.; NASEEF, G. S.; BARNETTE, D. J.; SKROBAL, M.; GREVENLINK, J.; ANDERSON, R. R. A pilot study of in vivo immediate tissue contraction. Lasers in Surgery and Medicine, v. 24, p. 133-141, 1999.

ROSS, R.; BORNSTEIN, P. Elastic fibers in the body. American Scientist, v. 224, n. 6, p. 44-52, 1971.

ROSS, R.; GREENLEE, T. K. Recent observations on elastic fibers and elastogenesis. In: Electron microscopy. 2. ed. Tokyo: Maruzen Co. LTD, 1966. $557 \mathrm{p}$. 
ROSSI, L. A.; BRAGA, E. C.; BARRUFFINI, R. C.; CARVALHO, E. C. Childhood burn injuries: circumstances of occurrences and their prevention in Ribeirão Preto, Brazil. Burns, v. 24, n. 5, p. 416-419, 1998.

SAARIALHO-KERE, U. K.; CHANG, E. S.; WELGUS, H. G. Direct localization of collagenase and tissue inhibitor of metalloproteinases ezpression in wound healing associated with ulcerative pyogenic granuloma, The Journal of Clinical Investigation, v. 90, p. 1952-1957, 1992.

SADER, S. L.; COUTINHO NETTO, J.; BARBIERI NETO, J.; MAZZETTO, A. S.; ALVES JUNIOR, P. A.; VANNI, J. C.; SADER, A. A. Substituição parcial do pericárdio de cães por membrana de látex natural. Revista Brasileira de Cirurgia Cardiovascular, v. 15, p. 338-344, 2000.

SANTOS, V. L. C. G. Avanços tecnológicos no tratamento de feridas e algumas aplicações em domicílio. In: . Atendimento domiciliar: um enfoque gerontológico. São Paulo: Atheneu, 2000. p. 265-306.

SERGEI, P. A. Regulação do complexo citocina na fibrose tecidual. Life Sciences, v. 72, p. 631-643, 2002.

SILVER, I. A. Cellular microenvironment in healing and nonhealing wounds. In: Soft and Hard Tissue Repair. New York: Praeger Publishers, 1984.

SOUSA, L. C. A.; PIZA, M. R. T.; COUTINHO-NETTO, J.; RUIZ D. B.; SCHMIDT, V. $B$. Latex biomembrane: A new method to coat the open cavity in tympanomastoidectomies. Revista Brasileira de Otorrinolaringologia, v. 73, n. 3, p. 331-336, 2007.

SPRINGER, T. A. Traffic signal for lymphocyte circulation and leukocyte migration: the multistep paradigm. Cell, v. 76, p. 301-314, 1994.

TARLOW, M. M.; NOSSA, R.; SPENCER, J. M. Effective management of difficult surgical defects using tissue-engineered skin. Dermatologic Surgery v. 27, p. 7174, 2001.

THOMAS, D. W.; ONEILL, I. D. HARDING, K. G. Cutaneous wound healing: a current perspective. Journal of Oral and Maxillofacial Surgery, v. 53, p. 442-447, 1995. 
THOMPSON, E. Quantitative microscopy analysis. Journal of Geology, v. 38, p. $193,1930$.

TUJI, F. M.; ALMEIDA, S. M.; BÓSCOLO, F. N.; MANZI, F. R. Avaliação do efeito radioprotetor do selenito de sódio no processo de reparação tecidual em ratos. Radiologia Brasileira, v. 38, n. 5, p. 359-364, 2005.

UNIVERSIDADE DE SÃO PAULO. Faculdade de Medicina Veterinária e Zootecnia. Serviço de Biblioteca e Divulgação. Diretrizes para apresentação de dissertações e teses na Faculdade de Medicina Veterinária e Zootecnia da Universidade de São Paulo. 4. ed. rev. atual. ampl. São Paulo: FMVZ-USP, 2003. 84 p.

VAN WINKLE, W. The fibroblast in wound healing. Surgery, Gynecology \& Obstetrics, v. 124, p. 369, 1967.

WALDEN, J. L.; GARCIA, H.; HAWKINS, H. CROUCHET, J. R.; TRABER, L.; GORE, G. C. Both dermal matrix and epidermis contribute to an inhibition of wound contraction. Annals of Plastic Surgery, v. 45, p. 162-166, 2000.

WALKER, H. L.; MASON, J. A. D. A Standard animal burn. The Journal of Trauma, v. 8, p. 1049-1051, 1968.

WARD, R. S.; SAFLLE, J. R. Topical agents in burn and wound care. Physical Therapy, v 75, n. 6, p. 526-538, 1995.

WEISSMAN, G. Inflammation: Historical perspectives. In and clinical correlates. 2. ed. New York: Raven Press, p. 5-13,1992.

WILLIAMS, G. Pathophysiology of the burn wound. In: Total Burn Care. 2. ed. New York: Saunders, 2002. p. 514-22.

WITTE, M. B.; BARBUL, A. General principles of wound healing. The Surgical clinics of North America, v. 77, p. 509-528, 1997.

WITTE, M. B.; BARBUL, A. Role of nitric oxide in wound repair. The American Journal of Surgery, v. 183, p. 406-412, 2002. 
WOLF, S. E.; HERNDON, D. N. Queimaduras. In: Tratado de cirurgia: as bases biológicas da prática cirúrgica moderna. 16. ed. Rio de Janeiro: Guanabara Koogan, 2002. p. 379-400.

WOLMAN, M.; KASTEN, F. H. Polarized light microscopy in the study of the molecular structure of collagen and reticulin. Histochemistry, v. 85, p. 41-49, 1986

WOOD, G.C. The formation of fibrils from collagen solutions. Effect of chondroitin sulfate and other naturally occurring polyanions on the rate of formation, The Biochemical Journal, v. 75, p. 605, 1960.

YOUNG, B.; HEATH, J. W. Pele. In: Wheather histologia functional: texto e atlas em cores. Rio de Janeiro: Guanabara Koogan, 2001. p. 157-171.

YOUNG, T. The healing process: nurses are familiar with the management of wounds as they pass through the different stages of the healing process but do they understand the physiology behind tissue growth and repair as well as they could? The Journal of Practical Nursing, v. 22, n 10, p. 38-40, 2001.

ZAR, J. H. Bioestatistical analysis. 2. ed. New Jersey: Prentice-Hall, 1984.

ZHANG, S. X. Tegumento. In: Guanabara Koogan, 2001. p. $\overline{361-377 .}$

Atlas de histologia. Rio de Janeiro:

ZINK, M.; ROUSSEAU, P.; HOLLOWAY, G. A. Lowe extremity ulcers. In:

Acute and chronic wounds - nursing management. Missouri: Mosbi, $\overline{1992 . ~ p .164-~}$ 212. 
ANEXO A - Tabela de número randômicos

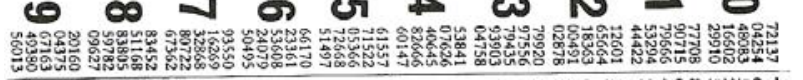

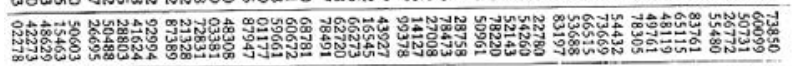

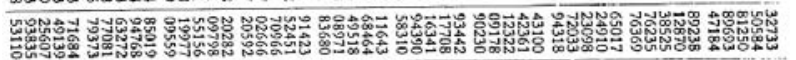

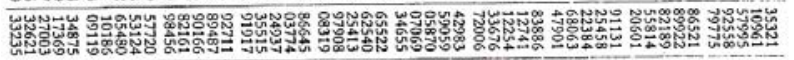

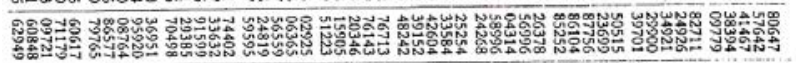

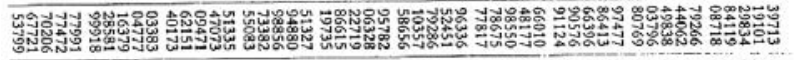

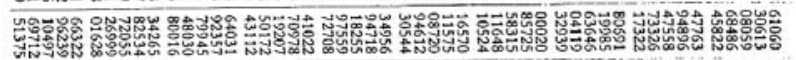

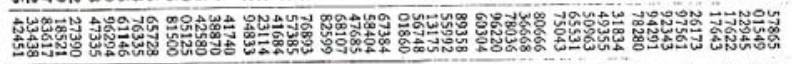

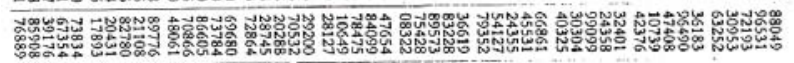

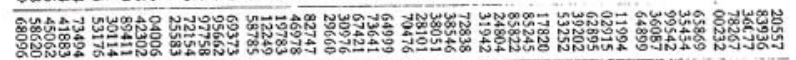

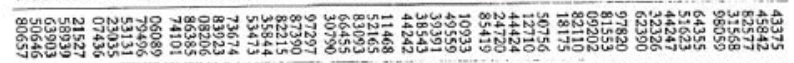

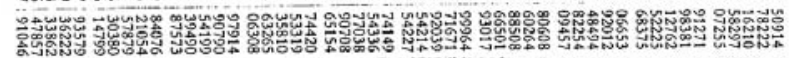

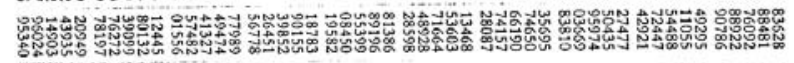

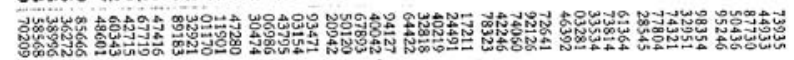

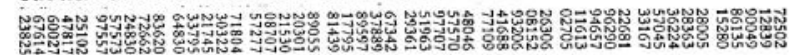

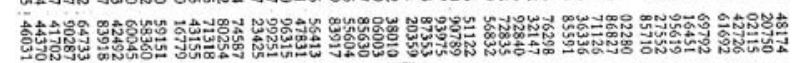

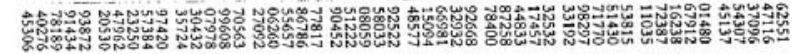

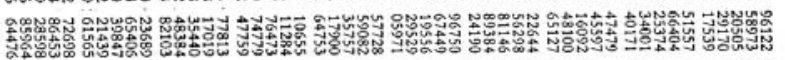

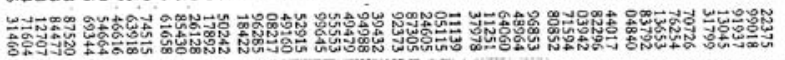

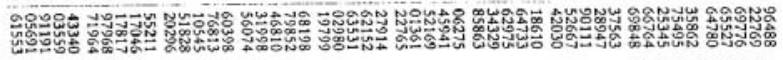

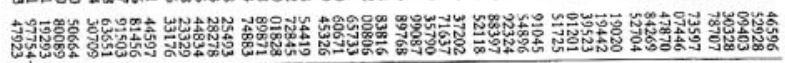

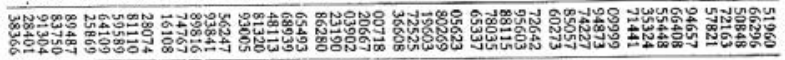

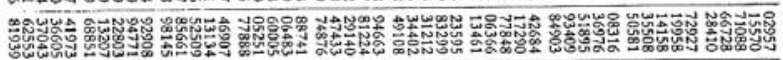

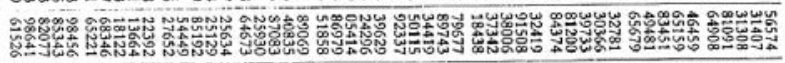

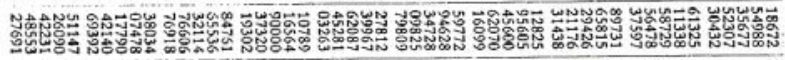

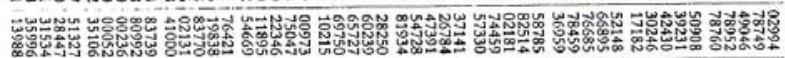

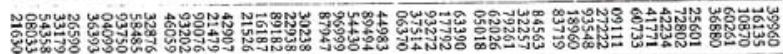

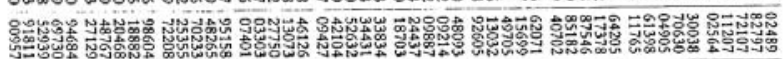

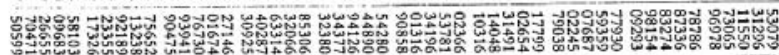

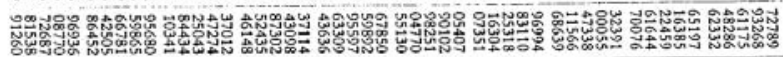

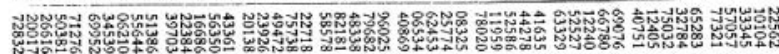

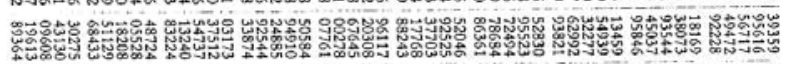

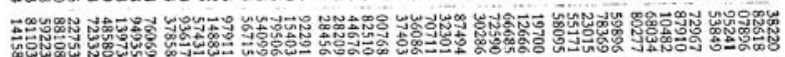

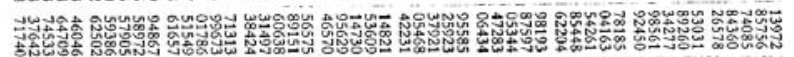

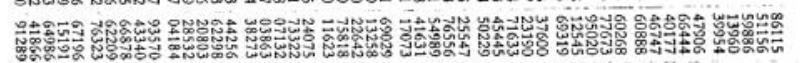
)

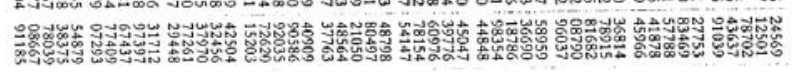

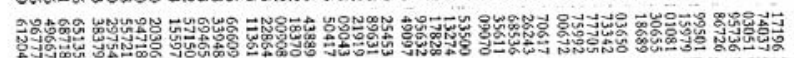

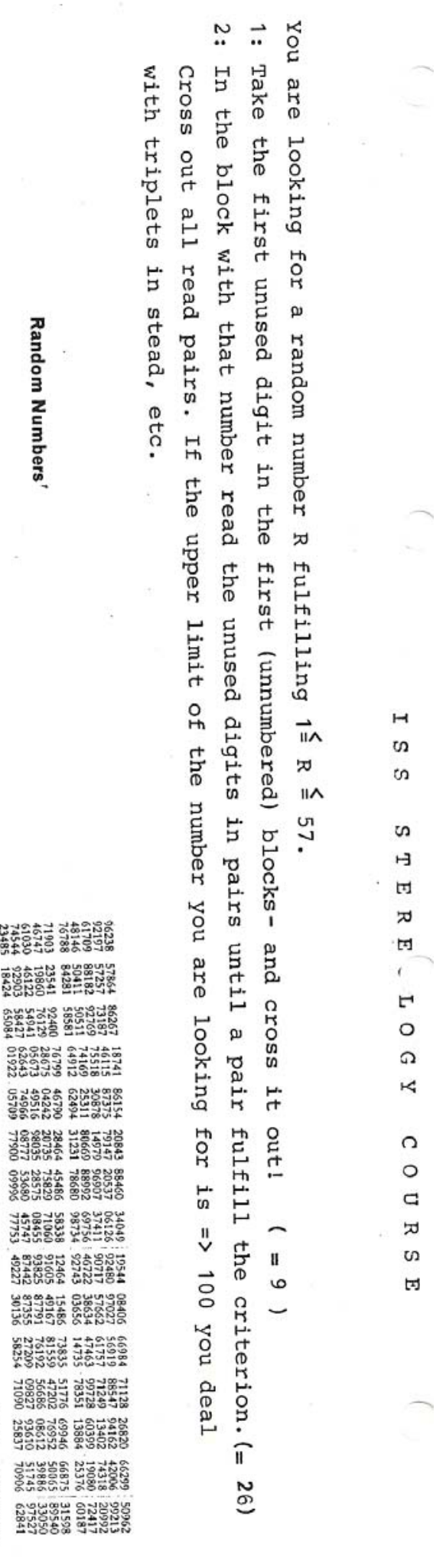

Fonte: Apostila do $2^{\text {nd }}$ ISS Brazilian Stereology Couse, São Paulo, Brazil, July $30^{\text {th }}-$ August $3^{\text {rd }}, 2007$. 
ANEXO B - Sistema teste utilizado para a quantificação estereológica

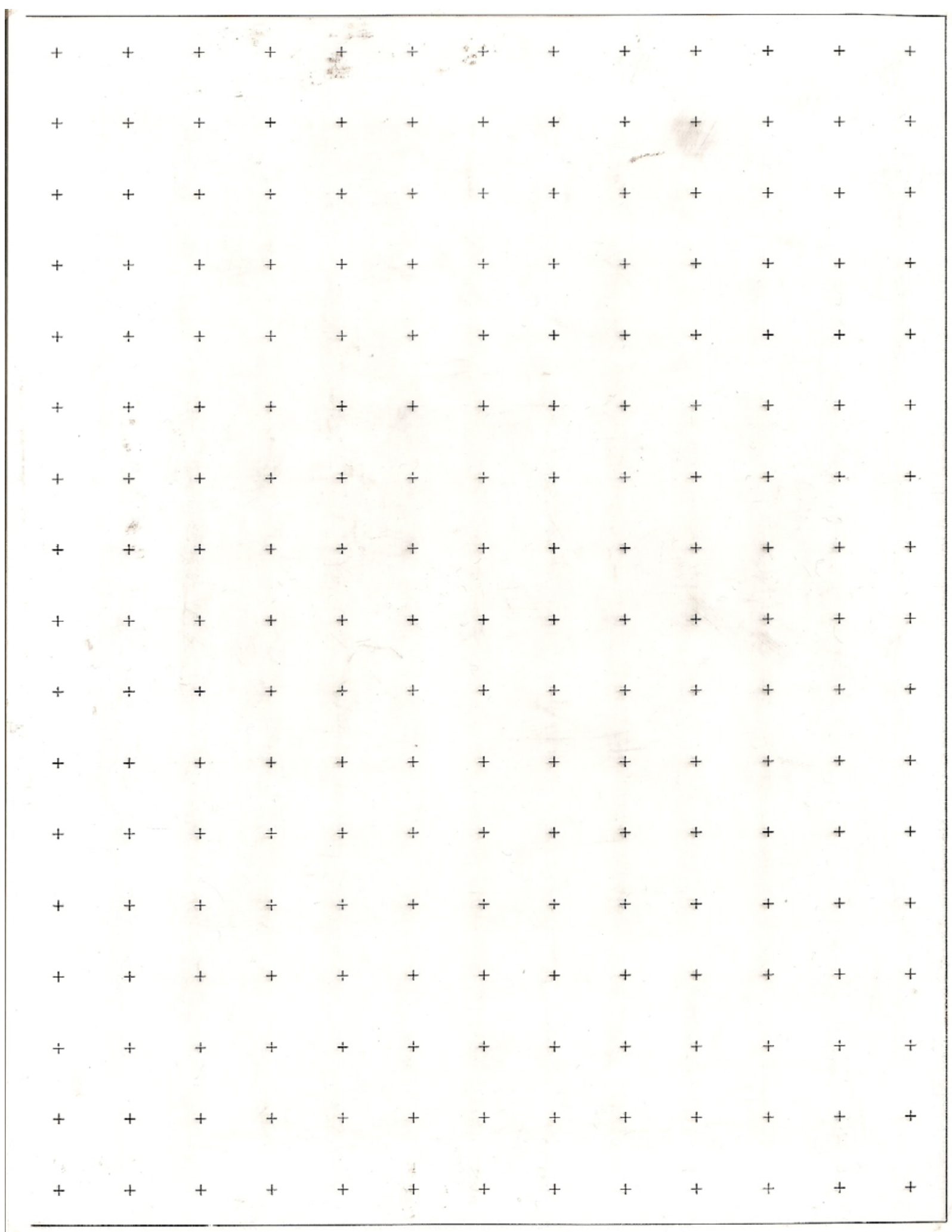

Fonte: Apostila do $2^{\text {nd }}$ ISS Brazilian Stereology Couse, São Paulo, Brazil, July $30^{\text {th }}-$ August $3^{\text {rd }}, 2007$. 
ANEXO C - Sistema teste contendo linhas de inclusão e exclusão utilizado para a quantificação estereológica.

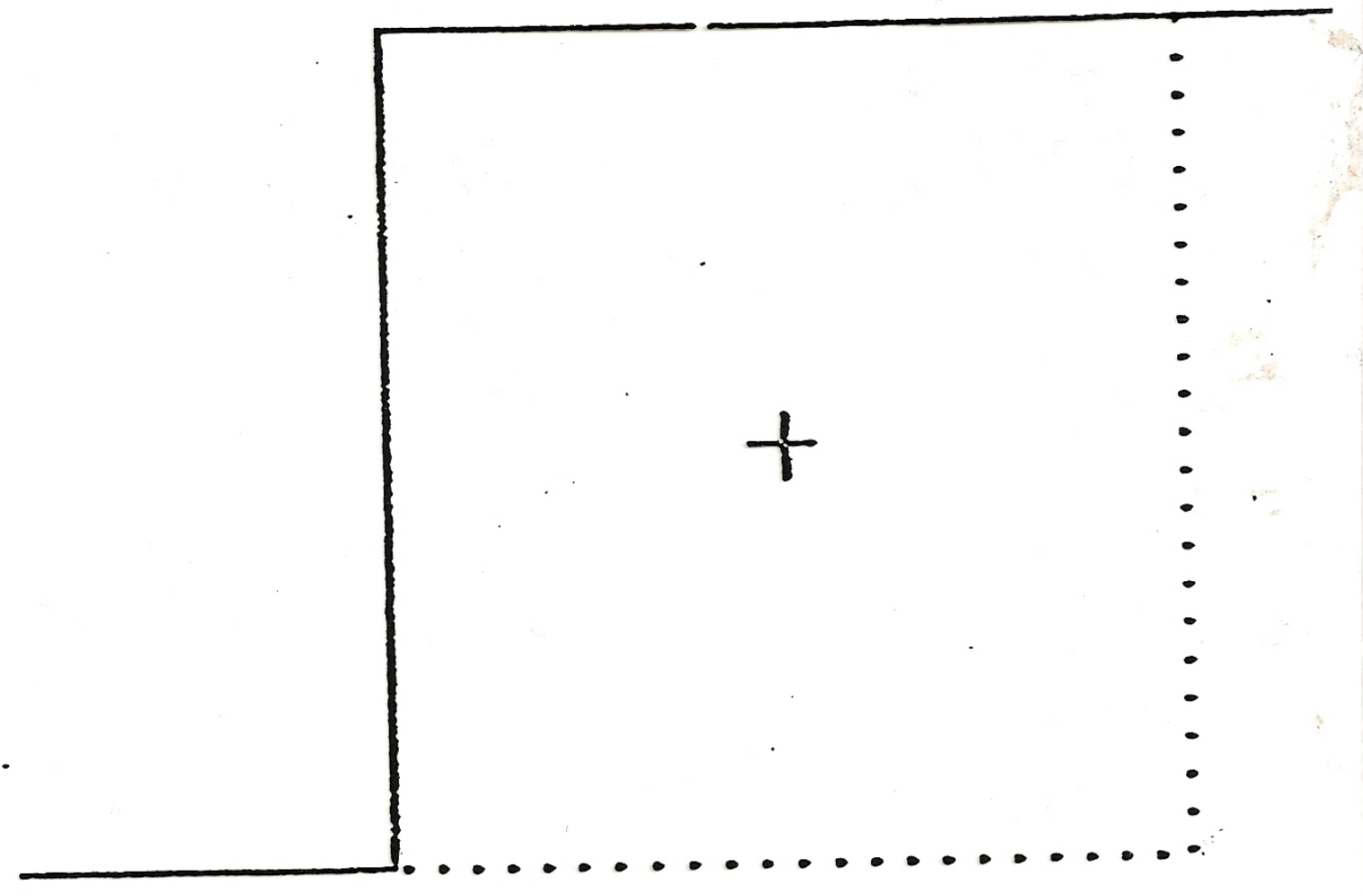

Fonte: Apostila do $2^{\text {nd }}$ ISS Brazilian Stereology Couse, São Paulo, Brazil, July $30^{\text {th }}-$ August $3^{\text {rd }}, 2007$. 